\title{
Effects of In-Situ Oil-Shale Retorting on Water Quality Near Rock Springs, Wyoming, Volume I
}

\section{Final Report}

J.B. Lindner-Lunsford

C.A. Eddy

M. Plafcan

H.W. Lowham

Work Performed Under Contract No.: DE-AI21-88MC25200

\author{
For \\ U.S. Department of Energy \\ Office of Fossil Energy \\ Morgantown Energy Technology Center \\ P.O. Box 880 \\ Morgantown, West Virginia 26507-0880
}

\section{By}

U.S. Geological Survey

Water Resources Division

2617 East Lincolnway, Suite B

Cheyenne, Wyoming 82001

December 1990 


\section{DISCLAIMER}

This report was prepared as an account of work sponsored by an agency of the United States Government. Neither the United States Government nor any agency Thereof, nor any of their employees, makes any warranty, express or implied, or assumes any legal liability or responsibility for the accuracy, completeness, or usefulness of any information, apparatus, product, or process disclosed, or represents that its use would not infringe privately owned rights. Reference herein to any specific commercial product, process, or service by trade name, trademark, manufacturer, or otherwise does not necessarily constitute or imply its endorsement, recommendation, or favoring by the United States Government or any agency thereof. The views and opinions of authors expressed herein do not necessarily state or reflect those of the United States Government or any agency thereof. 


\section{DISCLAIMER}

Portions of this document may be illegible in electronic image products. Images are produced from the best available original document. 
U.S. DEPARTMENT OF THE INTERIOR MANUEL LUJAN, JR., Secretary

U.S. GEOLOGICAL SURVEY

Dallas L. Peck, Director

For additional information

write to:

District Chief

U.S. Geological Survey

2617 E. Lincolnway, Suite B

Cheyenne, Wyoming 82001 


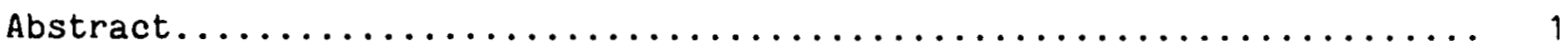

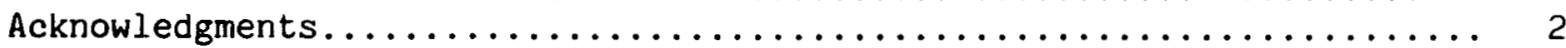

Executive Summary .................................

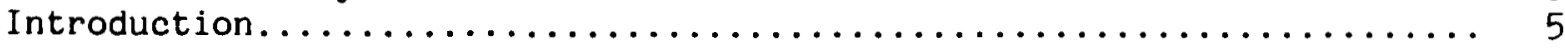

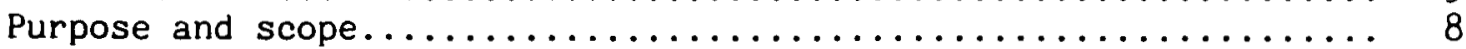

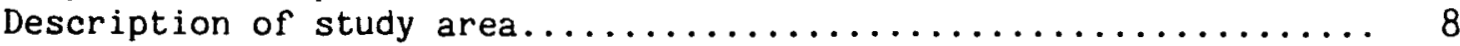

Regional setting............................ 8

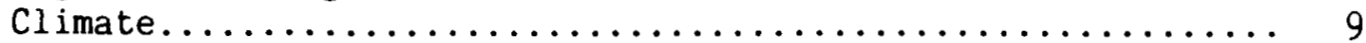

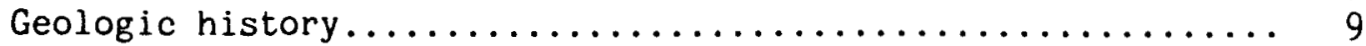

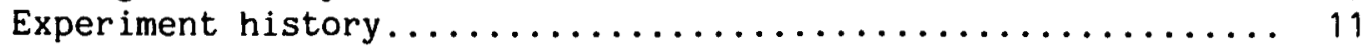

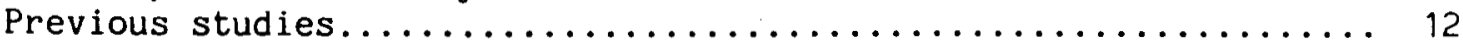

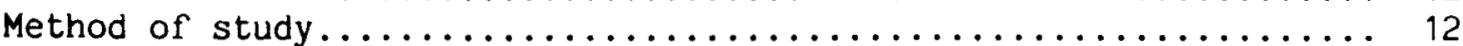

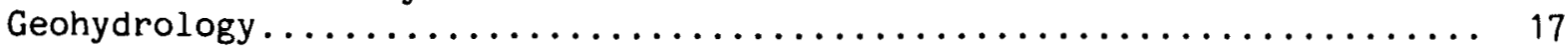

Lithology ...................................... 17

Hydrologic properties of the Tipton aquifer............... 20

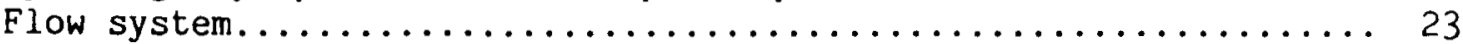

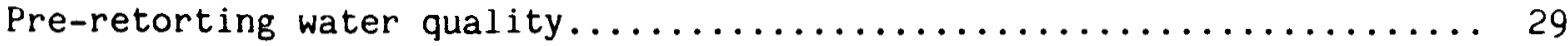

Effects of retorting experiments on water quality .............. 31

Water produced during retorting experiment................ 31

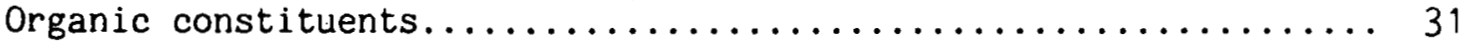

Inorganic constituents............................. 53

Indications of movement of contaminated water............. 65

Potentially applicable remediation techniques.................. 66

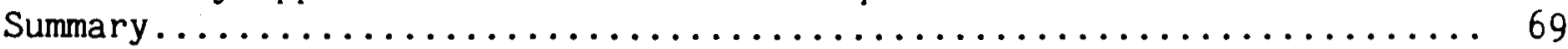

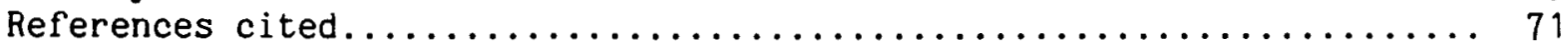

PLATE

Plate 1. Aerial photograph showing location of hydrologic data sites and potentiometric surface of Tipton aquifer during August 1989.

\section{FIGURES}

Figure 1. Map showing location of the study area.............. 6

2. Map showing location of in-situ oil-shale experimental sites and hydrologic-data sites................. 7

3. Diagrammatic geologic section near site $9 . \ldots \ldots \ldots \ldots \ldots \ldots .10$

4. Chart showing relation of geohydrologic units to geologic

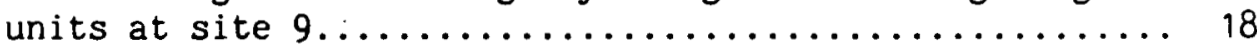

5. Map showing altitude and configuration of top of Tipton

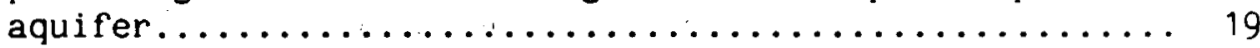

6. Map showing potentiometric surface for lower part of produced zone in Tipton aquifer in August $1989 \ldots \ldots \ldots 24$

7-12. Maps showing areal distribution of selected organic constituents analyzed in 1989:

7. Acetone concentrations................... 43

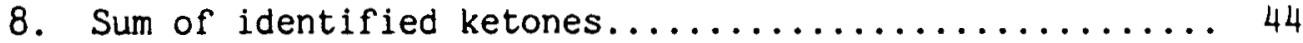

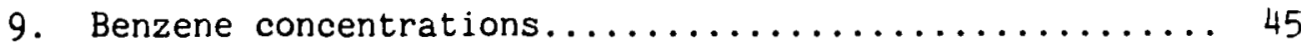

10. Sum of identified phenols.................. 46

11. Total xylenes.......................... 47 
12. 2-propanol,2-methyl concentrations............. 48

13. Map showing location of geologic sections........... 49

14-16. Geologic sections showing vertical distribution of concentration of selected organic constituents:

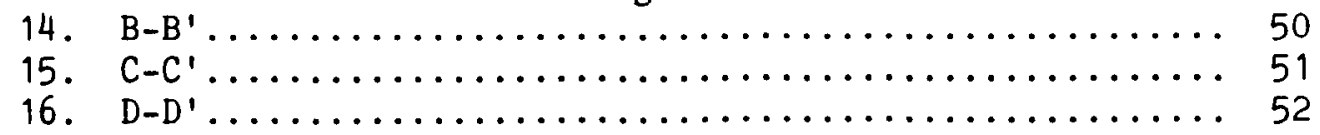

17-20. Maps showing areal distribution of ratios of selected cations, $\mathrm{pH}$, and concentration of molybdenum:

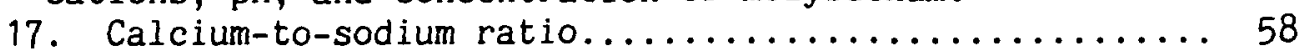

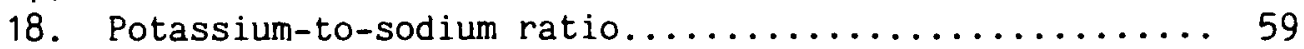

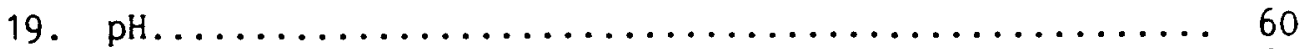

20. Concentration of molybdenum................. 61

21-23. Geologic sections showing vertical distribution of ratios of selected cations, $\mathrm{pH}$, and concentration of molybdenum:

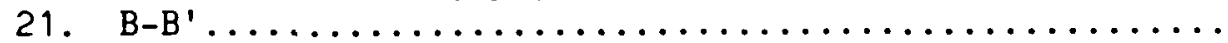

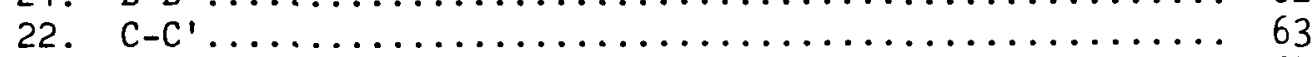

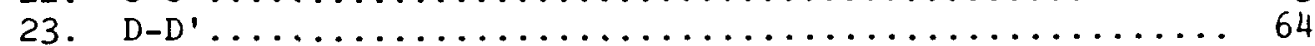

TABLES

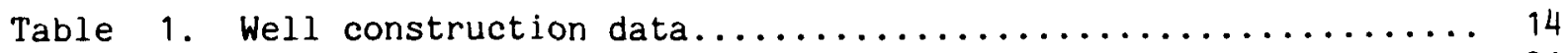

2. Aquifer test results and method of analysis............. 21

3. Water levels at Rock Springs sites, $1975-89 \ldots \ldots \ldots \ldots \ldots \ldots 26$

4. Statistical summary of selected constituents and properties in water samples collected from wells open to the produced zone of the Tipton aquifer at site 9 before retorting or

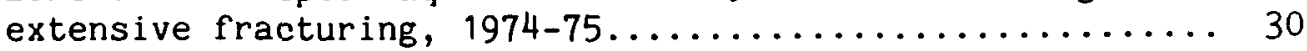

5. Selected volatile and semivolatile organic compounds detected in water samples collected from observation wells

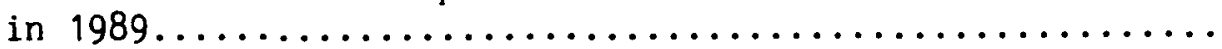

6. Volatile and semivolatile organic compounds, frequency of detection, maximum concentration, and location of maximum occurrence in water samples collected from observation

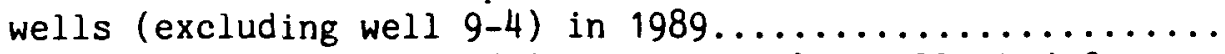
2 63 
CONVERSION FACTORS, VERTICAL DATUM, AND ABBREVIATIONS

Multiply

cubic foot per second $\left(f t^{3} / s\right)$

foot ( $f t$ )

foot per day ( $f t / d)$

foot squared per day $\left(f t^{2} / d\right)$

inch (in.)

mile (mi)
By

0.02832

0.3048

0.3048

0.09290

2.54

1.609
To obtain

cubic meter per second meter

meter per day

meter squared per day

centimeter

kilometer

Temperature in degrees Fahrenheit $\left({ }^{\circ} \mathrm{F}\right)$ can be converted to degrees Celsius $\left({ }^{\circ} \mathrm{C}\right)$ as follows:

$$
{ }^{\circ} \mathrm{C}=5 / 9\left({ }^{\circ} \mathrm{F}-32\right)
$$

Sea level: In this report, "sea level" refers to the National Geodetic Vertical Datum of 1929 (NGVD of 1929)--a geodetic datum derived from an adjustment of the first-order level nets of the United States and Canada, formerly called "Sea Level Datum of 1929."

\section{Abbreviations}

Water-quality abbreviations

L liter

$\mathrm{mg} / \mathrm{L} \quad \mathrm{milligram}$ per liter

$\mathrm{mL}$ milliliter

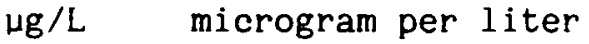

$\mu \mathrm{m}$ micrometer

$\mu \mathrm{S} / \mathrm{cm}$ microsiemen per centimeter

\section{Other abbreviations}

DOE U.S. Department of Energy

USEPA U.S. Environmental Protection Agency

WDEQ Wyoming Department of Environmental Quality

WRI Western Research Institute 


\section{ABSTRACT}

Experimental in-situ retorting techniques (methods of extracting shale oil without mining) were used from 1969 to 1979 by the Department of Energy's (DOE) Laramie Energy Technology Center (LETC) at a test area near Rock Springs in southwestern Wyoming. The retorting experiments at site 9 have produced elevated concentrations of some contaminants in the ground water. During 1988 and 1989, the U.S. Geological Survey, in cooperation with the U.S. Department of Energy, conducted a site characterization study to evaluate the chemical contamination of ground water at the site.

The oil shale is in the Tipton Shale Member of the Green River Formation of Eocene age, which is composed of interbedded shale, oil shale, and tuff with discontinuous beds of sandstone, marlstone, and siltstone. Hydraulic conductivities in the aquifer are small; eight slug tests conducted in 1989 yielded values ranging from no measurable aquifer response to 1.6 feet per day. Water in the Tipton Shale Member moves mainly through tuff or sandstone beds, bedding planes, and fractures; very little water moves through unfractured shale. A regional aquifer, the Wasatch aquifer (part of the Wasatch Formation of Eocene age), underlies the Tipton and is separated from it by a confining unit more than 200 feet thick.

Water samples from 34 wells were analyzed; more than 70 identifiable organic compounds were detected using a combination of gas chromatography and mass spectrometry analytical methods. Many organic contaminants--aromatic hydrocarbons, phenols, azaarenes, and aliphatic ketones--can be attributed to the retort experiments; other contaminants are the result of the alkaline ground water dissolving naturally occurring humic and fulvic acids in the shale. A sample from a well about $3 / 8$ mile downgradient from the retort area had concentrations of phenols as large as 2,300 micrograms per liter, and a sample from another well, 1/2 mile downgradient, had concentrations of ketones more than 11,000 micrograms per liter. Some nonpolar organic compounds that are present in the retort chamber have not been detected, or were detected only at low concentrations, in wells more than a few hundred feet downgradient from the retort chamber; these compounds may have been adsorbed onto organic material in the shale.

Concentrations of many dissolved inorganic constituents, including dissolved solids, sodium, total organic carbon, fluoride, arsenic, boron, and molybdenum, in the water before retorting began, exceeded drinking-water regulations. The presence of other constituents, including many nitrogen and sulfur species, are the result of the retort experiments. The $\mathrm{pH}$ of the water samples collected in 1989 ranged from 8.1 to 13.2. The pH values ranging from approximately 8.1 to 11 can be attributed to the dissolved carbonate minerals of natural origin, such as nahcolite and trona. However, $\mathrm{pH}$ values greater than about 11 may be caused by slaking of lime created by the retort process. Also attributed to the retort experiment are the high ratios of calcium and potassium to sodium compared to uncontaminated ground water at the site. 
Contaminants from the retort site have not been detected in either the underlying Wasatch confining unit or nearby Bitter Creek. Hydraulic-head data indicate that gradients in the study area in most places are upward from the Wasatch aquifer to the shallower Tipton aquifer, and downward from the upper sandy layer in the Tipton aquifer to the stratigraphic equivalent of the produced zone. Two sets of streamflow measurements on Bitter Creek upstream and downstream of the retort site indicate that the stream is losing water in this reach.

This report provides information that can be used to evaluate possible remedial action for the site. Remediation techniques that may be applicable include those techniques based on removing the contaminants from the aquifer and those based on immobilizing the contaminants. Before a technique is selected, the risks associated with the remedial action (including the noaction alternative) need to be assessed, and the criteria to be used for decisions regarding aquifer restoration need to be defined.

\section{ACKNOWLEDGMENTS}

The authors would like to thank Mr. Dennis Stenger, U.S. Bureau of Land Management, for allowing equipment to be stored at his office during drilling operations. The authors would also like to thank the U.S. Bureau of Land Management, the Union Pacific Railroad Company, and the Rock Springs Grazing Association for permitting access to their land for drilling and sampling. In addition, the authors gratefully acknowledge the assistance of Jerry Leenheer and Larry Barber, U.S. Geological Survey, for several helpful discussions concerning chemical processes affecting movement of organic compounds. 


\section{EXECUTIVE SUMMARY}

During the oil shortage of the 1970s, the U.S. Department of Energy (DOE) conducted experiments to test in-situ methods of oil recovery from the large reserves of oil shale in Colorado, Wyoming, and Utah. These experiments involved different methods of fracturing the oil-shale formation and various techniques for heating the oil shale in place to extract the oil from the shale. These processes produced, along with the oil, a variety of organic and inorganic by-products, some of which have not been removed. On May 25, 1988, the Wyoming Department of Environmental Quality (WDEQ) issued a notice of violation to DOE. DOE was ordered to perform a site characterization as the first step in restoring the ground water to its original condition. This report, prepared by the U.S. Geological Survey in cooperation with DOE, presents the results of that study.

The oil shale is in the Tipton Shale Member of the Green River Formation of Eocene age, which is composed of interbedded shale, oil shale, and tuff with discontinuous beds of sandstone, marlstone, and siltstone. Hydraulic conductivities in the aquifer are small; eight slug tests conducted in 1989 yielded values ranging from no measurable aquifer response to 1.6 feet per day. Water in the Tipton Shale Member moves mainly through tuff or sandstone beds, bedding planes, and fractures; little water moves through unfractured shale. A regional aquifer, the Wasatch aquifer (part of the Wasatch Formation of Eocene age), underlies the Tipton and is separated from it by a confining unit more than 200 feet thick.

Two potential pathways by which the contaminated water might move from the retort site were investigated: (1) vertical flow, consisting of interformational leakage downward into the underlying wasatch aquifer; and (2) lateral flow through tuff beds, bedding planes, and fractures in the shale, or through a sandy layer at the top of the Tipton aquifer, to discharge to nearby Bitter Creek. The investigation led to the conclusion that neither of these pathways completely describes the flow conditions and contaminant movement documented in the study area. Hydraulic-head data indicated that the vertical gradient in most parts of the study area is upward from the Wasatch aquifer to the shallower Tipton aquifer; therefore, it is unlikely that the Wasatch aquifer could be contaminated by water from the overlying Tipton aquifer. The potentiometric-surface data also indicated the potential for movement of contaminants toward Bitter Creek because the areal gradient is generally toward the southwest. However, the small hydraulic conductivities measured in the Tipton aquifer indicate little actual movement of water is taking place. Water discharging from the Tipton aquifer is probably lost by evapotranspiration; streamflow measurements on Bitter Creek upstream and downstream of the retort site indicate that the stream generally is losing water in this reach. Organic contaminants were not detected in water-quality samples from either Bitter Creek or the Wasatch confining unit.

Pre-retorting water quality in the Tipton aquifer at the site is variable areally, but generally is poor, with concentrations of sodium, bicarbonate and carbonate, and natural organic acids that greatly exceed drinking-water regulations. In some parts of the study area, the water is dark brown. More than 70 identifiable organic compounds were found during the present (1989) study; most of the organic contaminants--aromatic hydrocarbons, phenols, azaarenes, and aliphatic ketones--can be attributed to the retort experiments. 
Seventeen new wells were drilled as part of the present study, and those wells, in addition to wells already at the site, were sampled and the water was analyzed for major inorganic constituents, trace metals, sulfur species including thiocyanate, thiosulfate, tetrathionate, and total sulfur, and volatile and semivolatile organic compounds (EPA schedules 624 and 625). Interference problems made the sulfur species difficult to analyze. High concentrations of volatile and semivolatile organic contaminants, as well as other indicators associated with retort water, were detected in water samples from two wells, $25 \mathrm{U}$ and $32 \mathrm{U}$, screened in the upper part of the produced zone in the oil shale in the Tipton aquifer, about $3 / 8$ to $1 / 2 \mathrm{mile}$ downgradient of site 9 .

Results of the present study show that many of the organic contaminants are not moving conservatively, and, therefore, a conservative tracer is not appropriate to estimate future contaminant locations and concentrations. (A conservative tracer is a constituent that moves at exactly the same rate as the water and does not take part in any geochemical, biological, or other reactions in the natural environment. Where conservative tracers exist, they are generally useful indicators of rates of ground-water movement, contaminant dispersion, and mixing.) Benzene, for example, has been detected in measurable concentrations in only a few wells outside of the retort chamber. Movement of benzene, and several other nonpolar organic compounds such as azaarenes, may be retarded relative to movement of polar compounds and ions, probably because the nonpolar compounds are adsorbed onto organic material in the shale as the water moves slowly through fine-bedding planes and small fractures. Alternatively, these compounds could be degraded by microbiological activity before they have moved more than a few tens of feet from the retort chamber, but the high $\mathrm{pH}$ of the water in the Tipton aquifer makes this mechanism less likely than adsorption. Another possible degradation route may be the interaction of organic compounds with the inorganics at the high $\mathrm{pH}$ present in the ground water to form stable, nonsoluble compounds. Watersoluble acetone and phenols, by contrast, are widely dispersed throughout the study region, and have been detected in wells as far as $1 / 2 \mathrm{mile}$ from the retort chamber. In addition to volatile and semivolatile organic compounds, calcium-to-sodium and potassium-to-sodium ratios and $\mathrm{pH}$ were used in the present study to identify ground-water movement. Vertical distribution of these indicators, and the many very thin beds in the aquifer, imply a stratified system, where waters moving through the upper layers in the Tipton aquifer did not mix with deeper waters. The open-hole design of previous observation wells made it impossible to detect this stratification because their construction allowed water from different depths in the aquifer to mix in a sample. 
Acetone, the contaminant detected most frequently in the aquifer during the study, was present in 28 of 40 analyses. The maximum concentration detected in the aquifer was $980 \mu \mathrm{g} / \mathrm{L}$ at well 32U. No acetone was detected in the retort chamber during sampling in May 1989; however, acetone was present at a concentration of $120 \mathrm{\mu g} / \mathrm{L}$ in May 1989. Benzene was detected in 13 of 36 analyses in the aquifer at a maximum concentration of $17 \mathrm{\mu g} / \mathrm{L}$ (well 25U); it was present in the retort chamber in May 1989 at a concentration of 1,300 $\mu \mathrm{g} / \mathrm{L}$. Other compounds detected in 10 or more analyses were methylene chloride, 2-propanol,2-methyl, toluene, total xylenes, and bis (2-ethylhexyl) phthalate. The highest concentrations of total semivolatile organic compounds were found at well $25 \mathrm{U}$ (over 200,000 $\mu \mathrm{g} / \mathrm{L}$ ) and at well $32 \mathrm{U}$ (about $700,000 \mu \mathrm{g} / \mathrm{L}$ ). (Well locations are shown on Plate 1.) The retort chamber well (well 9-4) only had about $18,000 \mu \mathrm{g} / \mathrm{L}$ of semivolatile constituents, but had a greater concentration of volatile constituents than any other well, over $2,400 \mu \mathrm{g} / \mathrm{L}$. The largest concentration of volatile constituents detected in the aquifer (excluding well 9-4) was about $2,000 \mu \mathrm{g} / \mathrm{L}$ at well $27 \mathrm{~T}$.

Remediation techniques that may be applicable at the site include techniques based on removing the contaminants from the aquifer and those based on immobilizing the contaminants. Before a technology is selected for use, the risks associated with the remedial action (including the no-action alternative) need to be assessed, and the criteria to be used for decisions regarding aquifer restoration need to be defined.

\section{INTRODUCTION}

The oil crisis of the 1970s led to increased interest in the vast oilshale resources in Colorado, Utah, and Wyoming, and new technologies were developed to process these resources. Experimental in-situ retorting techniques (methods of extracting the oil in place without mining) were used from 1969 to 1979 by the Department of Energy's (DOE) Laramie Energy Technology Center (LETC) at a test area near Rock Springs in southwestern Wyoming (Figures 1 and 2). To extract shale oil using an in-situ process, the oil-shale formation is fractured and then heated. The heat releases hydrocarbons from the shale, and nearby production wells pump the newly released shale oil to the land surface for further processing. Water, usually of poor quality, also is released during the retorting process.

On May 25, 1988, the Wyoming Department of Environmental Quality (WDEQ) issued a notice of violation to DOE. The U.S. Geological Survey, in cooperation with DOE, began a site characterization study, the first step in restoring the ground water to its original condition. The principal objective of the study was to determine the nature and current extent of contamination in the study area. 


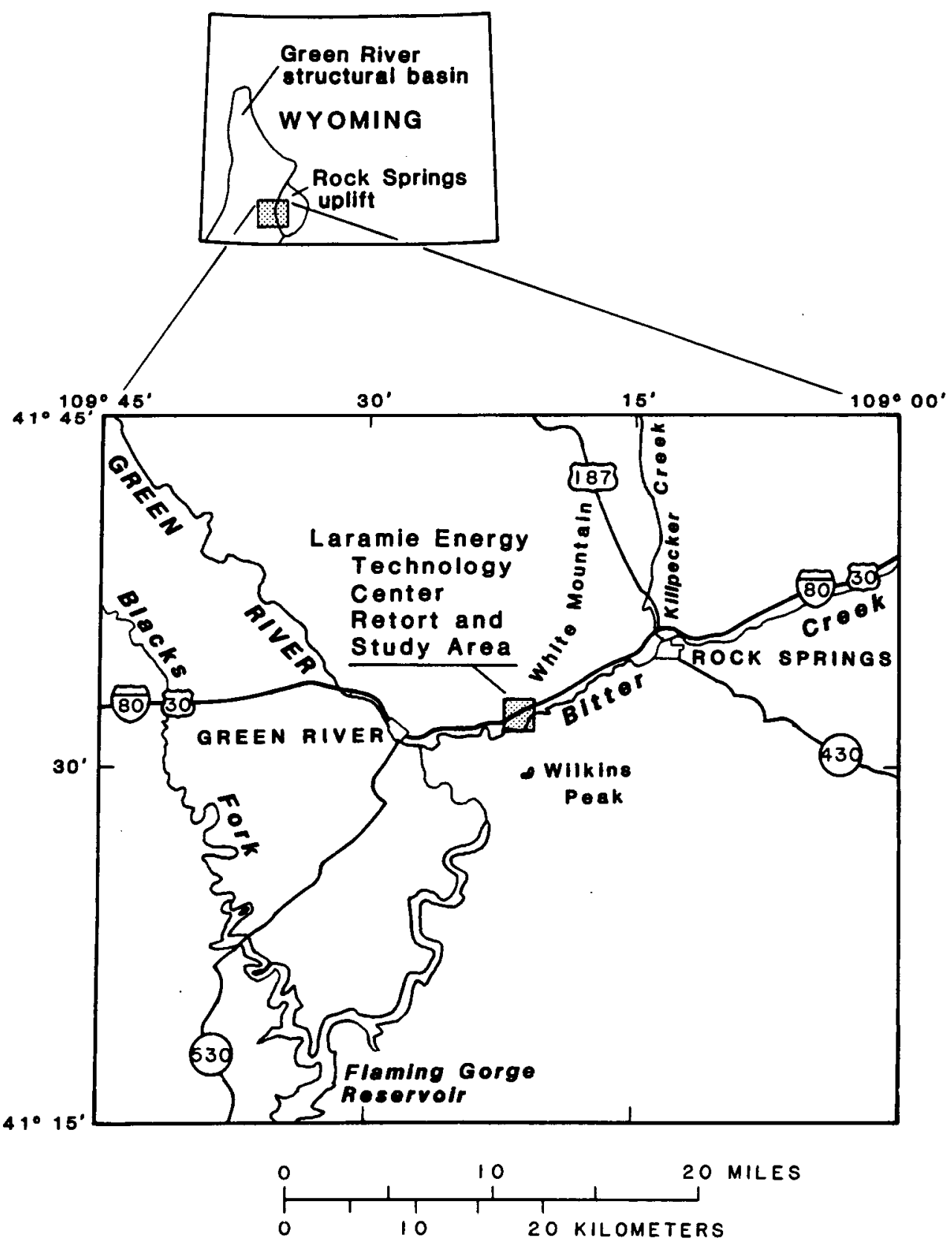

Figure 1.--Location of the study area. 


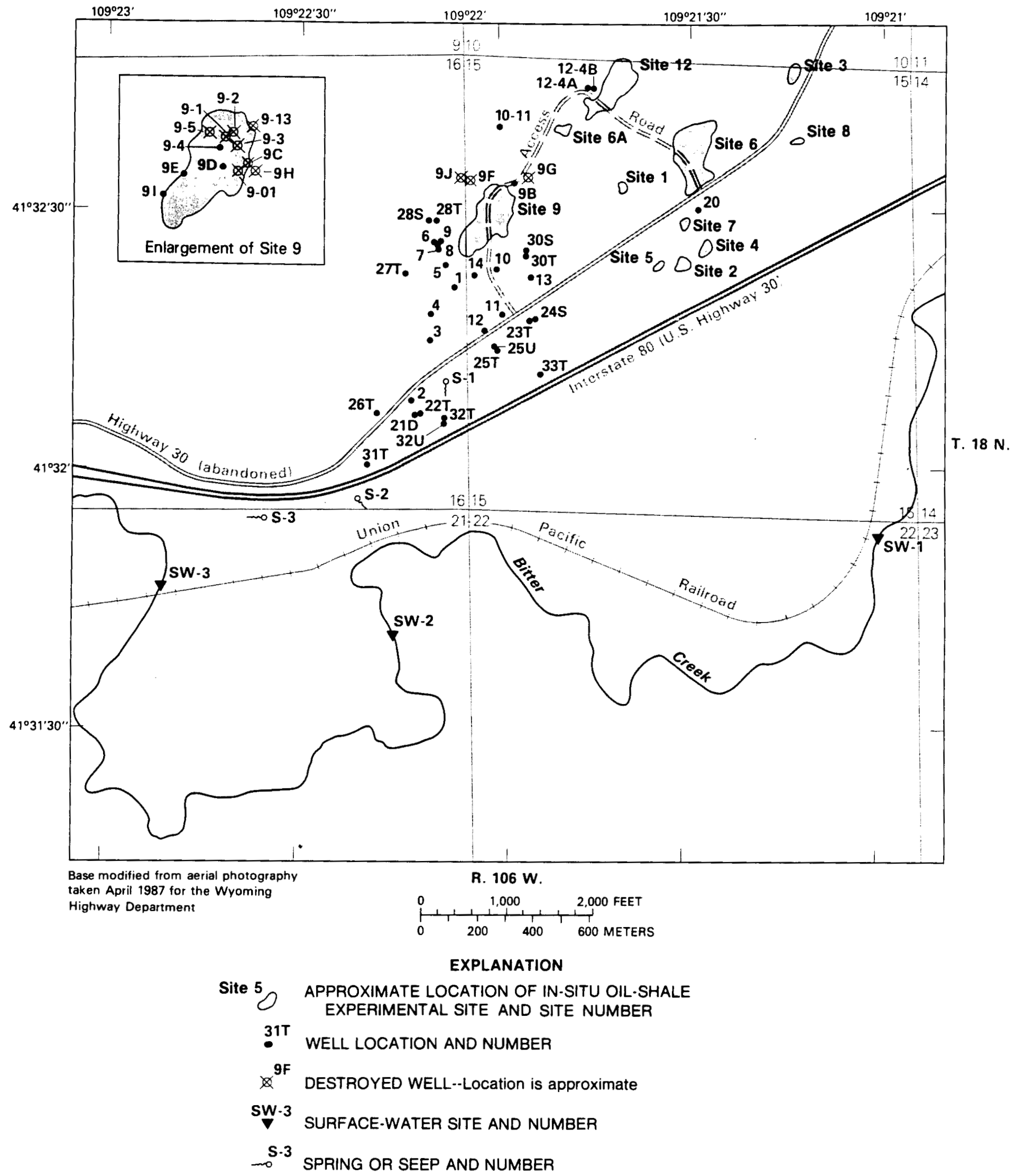

Figure 2.--Location of in-situ oil-shale experimental sites and hydrologic-data sites. 
This report presents the results of the study of the geohydrologic aspects of the oil-shale retorting experiment area. The study was descriptive in nature; basic chemical processes affecting the contaminants were not addressed. Remediation techniques that might be applicable to the site are identified. The study concentrated primarily on site 9 because it was the site named in the notice of violation. Also, the site is closest in the direction of the regional gradient to a potential discharge area at Bitter Creek, the best historical data are available for this site, and many wells already existed at the beginning of the study.

\section{Description of Study Area}

The hydrology of an aquifer system is dependent on basin-wide, local and site-specific factors. Local climate controls availability of water to recharge the aquifer. The amount of water available to move through a system depends on amount of recharge, which in turn depends on the permeability and storage of overlying soils, amount of precipitation, potential evaporation, and transpiration. The geologic history of the basin affects type and amount of sediments deposited, history of uplifting and erosion, amount of folding, faulting, and fracturing of the formations, and type and amount of overlying sediments. Depositional history may also be responsible for the presence of soluble salts or organic material, which could affect water quality. Basinwide and local factors are discussed in the following sections; site-specific factors are addressed in the "Geohydrology" and "Water Quality" sections.

\section{Regional setting}

The study area is in the Green River basin of southwestern Wyoming about 7 miles west of the city of Rock Springs in sections $15,16,21$, and $22, T .18$ N., R. 106 W. (Figure 1). The area is a high desert plateau--land-surface elevations range from less than $6,200 \mathrm{ft}$ above sea level at Bitter Creek to about $6,700 \mathrm{ft}$ above sea level along the eroded slopes of White Mountain (Figure 1). Topography is rugged to gently rolling. Vegetation is sparse, consisting mostly of sagebrush, grasses, and shrubs. Trees generally are absent. Soils are derived primarily from weathered shales and sandstones, and therefore tend to be poorly drained, only moderately permeable, and have high runoff potential. - These soil characteristics limit the quantity of infiltration in the study area. In addition, the soils in some areas contain soluble salts (Lowham and others, 1985), which can be redissolved by water recharging the ground-water system. 
Climate

The climate in the study area is arid, with maritime-polar winds prevailing from the West. However, coastal mountain ranges cause most of the moisture to precipitate before reaching the Rock Springs area. The mean annual precipitation is 8.7 inches, with an annual snowfall of 34.9 inches (Wyoming Department of Administration and Fiscal Control, 1987). Precipitation occurs as light rain in the late spring and early summer, but as the summer progresses, the hot dry air often evaporates the rain before it reaches the ground. Evapotranspiration is greatest during July, but continues to be substantial well into the fall, because of the warm soil temperatures of the high desert (Lowham and others, 1985). The mean annual pan evaporation is between 65 and 70 inches, and estimated mean annual lake evaporation is 45 to 50 inches (Martner, 1986, p. 177). The warmest month is July, with an average high temperature of $83.4^{\circ} \mathrm{F}$ and a low of $53.0^{\circ} \mathrm{F}$. The coldest month is January, with an average high temperature of $29.4^{\circ} \mathrm{F}$ and a low of $10.6^{\circ} \mathrm{F}$ (Martner, 1986).

\section{Geologic history}

The geologic history of the Green River structural basin is described by Bradley (1964); the following description is modified slightly from the one presented by Lidstone (Lidstone and Anderson, Inc., written commun., 1989). The basin is a shallow synclinal structure separated from the adjacent Washakie basin by an anticlinal structure known as the Rock Springs uplift. The basin is underlain by rocks of the Tertiary Wasatch, Green River, and Bridger Formations. The study area is along the eastern edge of the Green River structural basin, on the westward-dipping limb of the Rock Springs uplift, and the Bridger Formation is not present. Towards the center of the basin and in the vicinity of the study area, the regional dip of these formations averages 1 to 1 1/2 degrees to the west. A diagrammatic geologic section near site 9 is shown in Figure 3 and the generalized lithology of site 9 is shown in Figure 4. A detailed stratigraphic column of site 9 can be found in Lidstone (Lidstone and Anderson, Inc., written commun., 1989).

The Rock Springs uplift was arched into a low dome by the end of the Cretaceous Period. According to an analysis of inferred dips within the Wasatch and Upper Cretaceous rocks adjacent to the uplift, the ancestral dome had a structural relief ranging from 1,000 to 2,500 ft (Bradley, 1964).

The mountains and hills that surround the Green River structural basin were in place at the beginning of the Tertiary Period. They provided the structural relief and the source of sediment to the basin. Apparently the downwarping of the basin, which began early in the Tertiary Period and continued uniformly through the Eocene Epoch, was responsible for the continuous sedimentation of the Wasatch and Green River Formations (Bradley, $1964)$. 


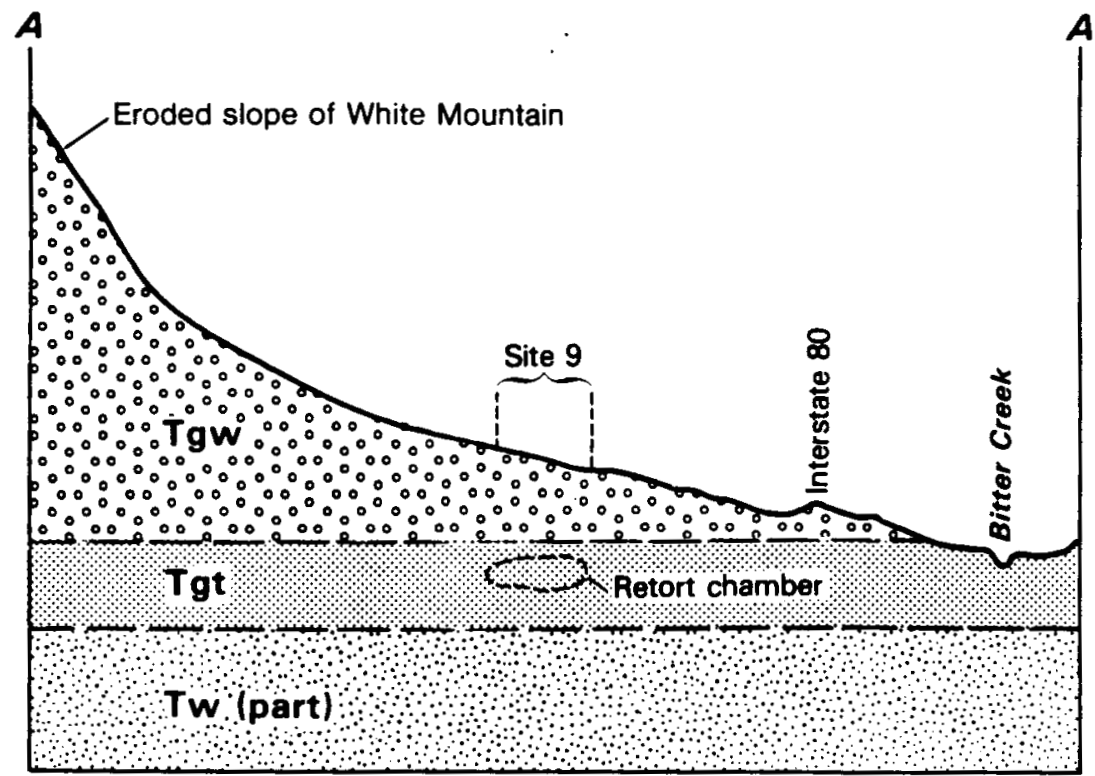

\section{EXPLANATION} J̃gw WILKINS PEAK MEMBER OF THE GREEN
RIVER FORMATION (TERTIARY)

Tgt TIPTON SHALE MEMBER OF THE GREEN RIVER FORMATION (TERTIARY)

TW. WASATCH FORMATION (TERTIARY) GEOLOGIC CONTACT--Approximately located

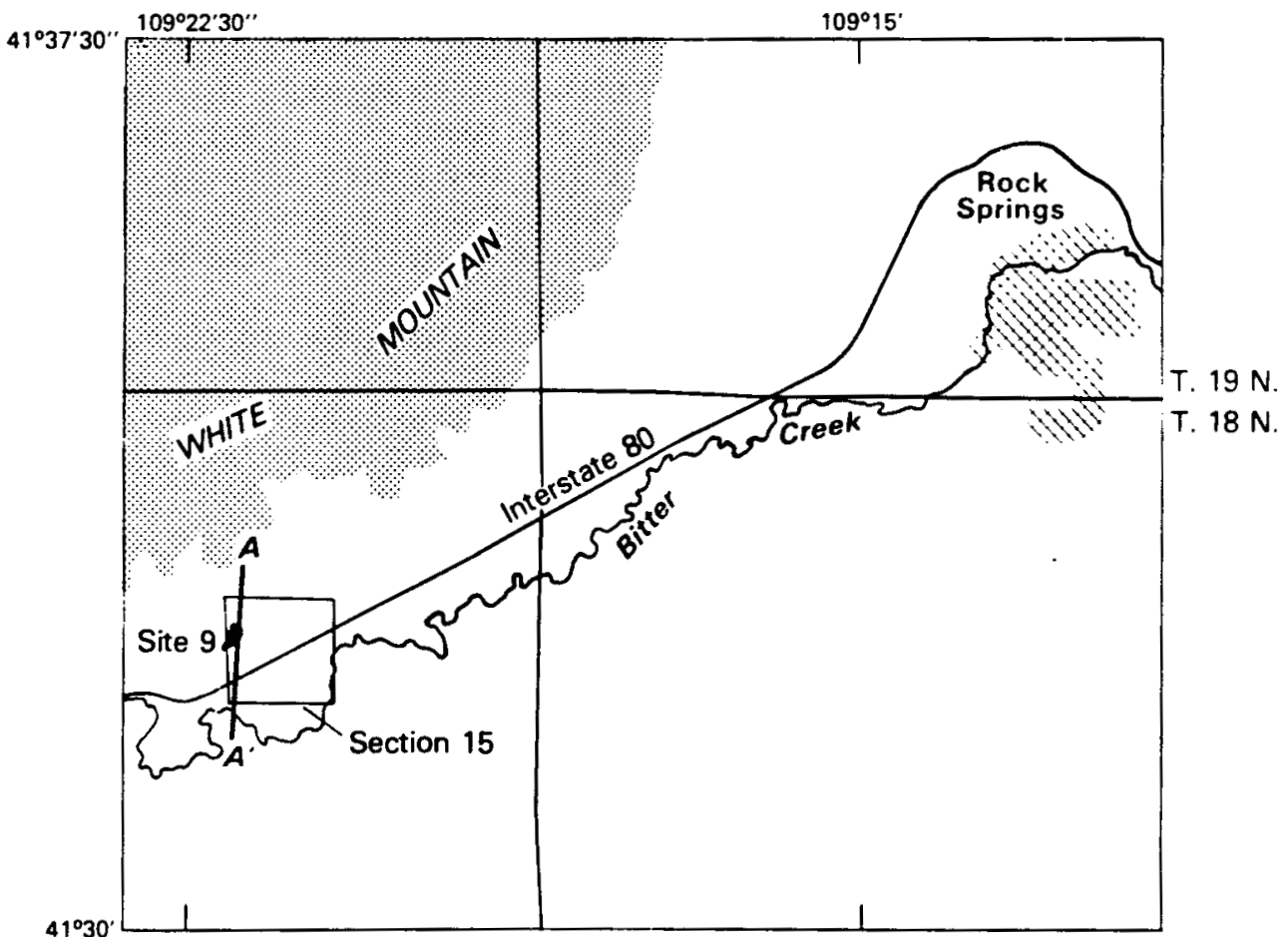

R. 106 W. R. 105 W.

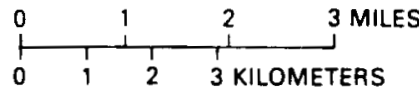

LOCATION MAP

Figure 3.--Diagrammatic geologic section near site 9 (Lidstone and Anderson, Inc., written commun., 1989) 
Most of the faults that intersect the Tertiary rocks in this part of Wyoming are localized along the margins of the major uplifts of pre-Tertiary rocks such as the Rock Springs uplift (Bradley, 1964). Although there are fractures, there is no known faulting in the study area. The Rock Springs uplift persisted as a structural feature throughout the depositional cycles of the Eocene sediments. The Rock Springs uplift did not reach its present structural relief until after the deposition of the Bridger Formation (late Eocene).

During the Eocene Epoch, the study area was under water, part of the bed of a large lake called Gosiute Lake. The lake initially was a fresh-water lake that shrank and became saline, then later filled with sediment. The large variety of plant and animal life associated with the lake is the source of the organic material that became the oil shale in the Tipton Shale Member of the Green River Formation (R.A. Wise, U.S. Geological Survey, written commun., 1989).

Following the deposition of these Eocene formations, compressive forces accentuated the Rock Springs uplift and steepened dips locally as much as 13 degrees (Bradley, 1964). These forces also were responsible for the primary fracture pattern in the study area, which runs 10 degrees east of north to 10 degrees west of south. Secondary deformation, masking the primary fracture orientation, occurred as a result of the combined effect of the compaction of the Tertiary deposits and their original basinward dip. This secondary deformation is manifested in the scatter associated with the fracture orientation. Existence of fractures also can be inferred from aerial photographs of the site (Plate 1). A dark gridlike pattern can be seen in the horseshoe-shaped area south of Interstate Highway 80 and enclosed by the bend in the railroad tracks near the bottom center of the photograph. The dark lines are caused by vegetation growing more densely where water is more available because of fracturing (C.C. Barton, U.S. Geological Survey, oral commun., 1989). The fracture traces are not visible north of the interstate highway where overburden is thicker.

\section{Experiment history}

The experimenters at LETC investigated the use of different fracturing methods--hydraulic, explosive, or a combination of both, and different retortchamber ignition methods and temperatures. Carpenter (1988) presents brief descriptions of the in-situ experiments at the Rock Springs test area. He states that 13 in-situ experimental sites were designated, numbered 1 through 12 and $6 \mathrm{~A}$ (Figure 2 and Plate 1). At sites 1, 2, 3, 5, 6A and 8 only fracturing--not ignition--experiments were carried out. Experiments were designed for sites 10 and 11, but were not conducted; hence, the sites are not shown on Figure 2 or Plate 1. Sites 4,6, 7, 9, and 12 were the only sites where the shale was ignited or ignition attempted, and only sites 4 and 9 produced more than a few barrels of shale oil. 
Three hydraulic fracture treatments were performed at site 9 between May 1974 and August 1975, and then the site was further fractured with slurried explosives. On April 5, 1976, the shale was ignited with an electric heater and a propane burner, and the experiment continued for about 5 months. Lawlor and others (1979) report that a zone about $15 \mathrm{ft}$ thick and $130 \mathrm{ft}$ wide displayed thermal effects of the burning at site 9. Long and others (1977, p. 120) report that 3,260 tons of oil shale were heated (21 percent of the target zone), producing an estimated 45,150 gallons of oil (Glover, 1988, p. 2) of which 2,483 gallons were recovered (removed to the surface). However, some of the shale oil produced was probably burned in situ, and, therefore, it is unlikely that the entire 42,667 gallons remain underground (J.A. Leenheer, U.S. Geological Survey, oral commun., 1989). More detailed case history and analyses of the experiment at site 9 were reported by Long and others (1977) and Farrier and others (1978).

At site 4, more shale oil was produced than at site 9 (Carpenter, 1988). However, recovery also was much more effective than at site 9--if shale oil was produced at site 4 at the same recovery efficiency that mass-balance calculations indicate it was produced at site 9 , then almost 95 percent of the oil produced at site 4 was recovered. Relatively little oil remains in the subsurface at site 4 to provide a potential source of ground-water contamination.

\section{Previous Studies}

Many studies have been done at the Rock Springs test area. EG\&G (Edgerton, Greer, and Gramerhausen) Washington Analytical Services Center, Inc. (1988) presents a bibliography of all studies published about the Rock Springs experiments from 1966 to 1982; the report lists 80 citations. Two U.S. Geological Survey reports dealing directly with site 9 have been published (Leenheer and Noyes, 1986; Glover, 1988). Detailed case history and analyses of the burn (Long and others, 1977; Farrier and others, 1978; and many other studies) are available. Background water quality is described by Virgona and others (1979), and samples of retort wastewater from site 9 were split among several laboratories (Farrier and others, 1980; Fox and others, 1978). Weand (1978) and Smith and Weand (1977) describe changes in water quality at the Rock Springs sites. Chemical analyses for major ions, trace elements, total sulfur, thiocyanate, thiosulfate, tetrathionate, 13 phenolic compounds, 9 polynuclear aromatic compounds, and 8 heterocyclic compounds from water samples collected during 1981-83 at 25 wells in the study area, and Bitter Creek upstream and downstream from the site 9 area, have been stored in computer-readable format at the U.S. Geological Survey offices in Cheyenne, Wyo. Ten wells were sampled in March 1988 by WDEQ and DOE (unpublished report prepared by Western Research Institute, 1988).

\section{Method of Study}

The principal objectives were met by investigations from two disciplines: geohydrology and water quality. Both approaches began with a survey of the literature. The geohydrologic approach also included correlation of well logs from both existing wells drilled during the late 1970s and early 1980s and new wells drilled for the present study, slug tests, and evaluation of fracture orientation. The water-quality approach consisted of estimation of direction of ground-water movement based on water-level altitude measurements, and delineation of the distribution of contaminants using the results of waterquality sampling at new and existing wells. 
Seventeen new wells (wells 20 to $33 \mathrm{~T}$ ) were drilled in two phases during January and May 1989. Wells were drilled by air rotary methods to minimize introduction of contaminants into the formation. Wells drilled for previous studies at the site (wells 1 through 14, 9A through 9C, 9E through 9I, and 9-1 through 9-5) were cased with steel through the Wilkins Peak confining unit and left as open holes in the Tipton aquifer, Wasatch confining unit or Wasatch aquifer; several of these wells were open to the Tipton aquifer for more than $100 \mathrm{ft}$. This long length of open hole produced a depth-averaged measurement of hydraulic head and a composite water-quality sample. The new wells drilled in 1989 were all cased with polyvinyl chloride casings and had screened intervals of only $10 \mathrm{ft}$. Pairs of wells were drilled at several sites to obtain information about vertical gradients in the formation. Wells were screened in the 8-ft sandstone layer at the top of the Tipton aquifer identified by Glover (1988) as a possible pathway for contaminant movement (well numbers with an "S" suffix in Table 1), in the Tipton aquifer in or near the stratigraphic equivalent of the produced zone (well numbers with a "T" suffix in Table 1; where two wells are screened in or near the produced zone, the shallower one has a "U" suffix and the deeper one has a "T" suffix), or near the bottom of the Tipton aquifer (well numbers with "D" suffix in Table 1). Figure 2 and Plate 1 show the locations of wells at the site; construction data for these wells are presented in Table 1.

Water-quality samples were collected during March, May, June, July, and August 1989. A total of 34 wells was sampled and the water was analyzed for major inorganic constituents, trace metals, sulfur species including thiocyanate, thiosulfate, tetrathionate, and total sulfur, and volatile and semivolatile organic compounds (U.S. Environmental Protection Agency schedules 624 and 625). One of the 34 wells, 9-4, was open to the site 9 retort chamber.

The water-quality sampling method preferred by the U.S. Geological Survey is to evacuate at least three times as much water from the well and surrounding aquifer as was present in the well casing itself, and then to collect a water-quality sample (William Alley, U.S. Geological Survey, written commun., 1987). Small aquifer hydraulic conductivity at the Rock Springs sites caused slow recovery rates at the observation wells, making this procedure impractical. Instead, the wells were bailed until dry or for 30 minutes, and allowed to refill overnight. 
Table 1.--Well construction data

$$
[--, \text { no data }]
$$

\begin{tabular}{|c|c|c|c|c|c|}
\hline $\begin{array}{c}\text { Well } \\
\text { number }\end{array}$ & $\begin{array}{c}\text { Construc- } \\
\text { tion } \\
\text { type }^{1} \\
\end{array}$ & $\begin{array}{c}\text { Open } \\
\text { interval } \\
\text { (feet) }\end{array}$ & $\begin{array}{c}\text { Geohydrologic } \\
\text { unit } \\
\text { sampled } \\
\end{array}$ & $\begin{array}{l}\text { Total } \\
\text { depth } \\
\text { (feet) } \\
\end{array}$ & Remarks \\
\hline $9-4$ & $\mathrm{P}$ & $138-178$ & $\begin{array}{l}\text { Tipton aquifer } \\
\text { (produced zone) }\end{array}$ & 188 & $\begin{array}{l}\text { Production well } \\
\text { used during retort } \\
\text { experiments. }\end{array}$ \\
\hline 1 & A & $95-200$ & Tipton aquifer & 200 & \\
\hline 2 & $A$ & $55-200$ & Tipton aquifer & 200 & Caved back to $80 \mathrm{ft}$. \\
\hline 3 & $\ddot{A}$ & $80-200$ & Tipton aquifer & 200 & \\
\hline 4 & $\ddot{A}$ & $112-200$ & Tipton aquifer & 202 & \\
\hline 5 & A & $110-202$ & Tipton aquifer & 202 & \\
\hline 6 & $\ddot{A}$ & $120-200$ & Tipton aquifer & 202 & \\
\hline 7 & A & $270-350$ & $\begin{array}{l}\text { Wasatch } \\
\text { confining unit }\end{array}$ & 350 & \\
\hline 8 & A & $350-450$ & $\begin{array}{l}\text { Wasatch } \\
\text { confining unit }\end{array}$ & 450 & \\
\hline 9 & $A$ & $460-1,020$ & Wasatch aquifer & 1,030 & \\
\hline 10 & A & $90-200$ & Tipton aquifer & 200 & \\
\hline 11 & A & $79-200$ & Tipton aquifer & 200 & \\
\hline 12 & A & $69-200$ & Tipton aquifer & 200 & \\
\hline 13 & A & $103-200$ & Tipton aquifer & 200 & \\
\hline 14 & A & $270-350$ & $\begin{array}{l}\text { Wasatch } \\
\text { confining unit }\end{array}$ & 350 & \\
\hline 20 & B & $110-120$ & Tipton aquifer & 120 & $\begin{array}{l}\text { Replacement well; } \\
\text { original well } \\
\text { failed. }\end{array}$ \\
\hline 21D & B & $150-160$ & $\begin{array}{l}\text { Tipton aquifer } \\
\text { (near base) }\end{array}$ & 160 & \\
\hline $22 \mathrm{~T}$ & B & $110-120$ & $\begin{array}{l}\text { Tipton aquifer } \\
\text { (below produced } \\
\text { zone) }\end{array}$ & 120 & \\
\hline $23 \mathrm{~T}$ & B & $130-140$ & $\begin{array}{l}\text { Tipton aquifer } \\
\text { (lower part of } \\
\text { produced zone) }\end{array}$ & 140 & \\
\hline $24 \mathrm{~S}$ & B & $40-50$ & $\begin{array}{l}\text { Tipton aquifer } \\
\text { (upper sandy } \\
\text { layer) }\end{array}$ & 50 & \\
\hline $25 \mathrm{~T}$ & B & $110-120$ & $\begin{array}{l}\text { Tipton aquifer } \\
\text { (lower part of } \\
\text { produced zone) }\end{array}$ & 120 & \\
\hline $25 \mathrm{U}$ & B & $60-70$ & $\begin{array}{l}\text { Tipton aquifer } \\
\text { (upper part of } \\
\text { produced zone) }\end{array}$ & 70 & $\begin{array}{l}\text { Replacement well; } \\
\text { original well at } \\
\text { this location aban- } \\
\text { doned at time of } \\
\text { drilling. }\end{array}$ \\
\hline
\end{tabular}


Table 1.--Well construction data--Continued

\begin{tabular}{|c|c|c|c|c|c|}
\hline $\begin{array}{c}\text { Well } \\
\text { number }\end{array}$ & $\begin{array}{c}\text { Construc- } \\
\text { tion } \\
\text { type } \\
\end{array}$ & $\begin{array}{c}\text { Open } \\
\text { interval } \\
\text { (feet) }\end{array}$ & $\begin{array}{c}\text { Geohydrologic } \\
\text { unit } \\
\text { sampled } \\
\end{array}$ & $\begin{array}{l}\text { Total } \\
\text { depth } \\
\text { (feet) }\end{array}$ & Remarks \\
\hline $26 \mathrm{~T}$ & B & $110-120$ & $\begin{array}{l}\text { Tipton aquifer } \\
\text { (lower part of } \\
\text { produced zone) }\end{array}$ & 120 & \\
\hline $27 \mathrm{~T}$ & B & $160-170$ & $\begin{array}{l}\text { Tipton aquifer } \\
\text { (lower part of } \\
\text { produced zone) }\end{array}$ & 170 & \\
\hline $28 \mathrm{~S}$ & B & $100-110$ & $\begin{array}{l}\text { Tipton aquifer } \\
\text { (upper sandy } \\
\text { layer) }\end{array}$ & 110 & \\
\hline $28 \mathrm{~T}$ & B & $155-165$ & $\begin{array}{l}\text { Tipton aquifer } \\
\text { (lower part of } \\
\text { produced zone) }\end{array}$ & 165 & \\
\hline $30 \mathrm{~s}$ & B & $80-90$ & $\begin{array}{l}\text { Tipton aquifer } \\
\text { (upper sandy } \\
\text { layer) }\end{array}$ & 90 & \\
\hline $30 T$ & B & $150-160$ & $\begin{array}{l}\text { Tipton aquifer } \\
\text { (lower part of } \\
\text { produced zone) }\end{array}$ & 160 & \\
\hline $31 T$ & B & $70-80$ & $\begin{array}{l}\text { Tipton aquifer } \\
\text { (lower part of } \\
\text { produced zone) }\end{array}$ & 80 & \\
\hline $32 U$ & B & $50-60$ & $\begin{array}{l}\text { Tipton aquifer } \\
\text { (upper part of } \\
\text { produced zone) }\end{array}$ & 60 & \\
\hline $32 \mathrm{~T}$ & B & $80-90$ & $\begin{array}{l}\text { Tipton aquifer } \\
\text { (lower part of } \\
\text { produced zone) }\end{array}$ & 90 & \\
\hline $33 \mathrm{~T}$ & B & $110-120$ & $\begin{array}{l}\text { Tipton aquifer } \\
\text { (lower part of } \\
\text { produced zone) }\end{array}$ & 120 & \\
\hline $9 \mathrm{~B}$ & A & $153-206$ & Tipton aquifer & 206 & \\
\hline $9 \mathrm{D}$ & A & -- & $\begin{array}{l}\text { Wasatch } \\
\text { aquifer }\end{array}$ & 900 & $\begin{array}{l}\text { Original water- } \\
\text { supply well for } \\
\text { experimenters at } \\
\text { site. }\end{array}$ \\
\hline $\begin{array}{l}9 \mathrm{E} \\
9 \mathrm{I}\end{array}$ & $\begin{array}{l}A \\
A\end{array}$ & $\begin{array}{l}122-175 \\
116-169\end{array}$ & $\begin{array}{l}\text { Tipton aquifer } \\
\text { Tipton aquifer }\end{array}$ & $\begin{array}{l}175 \\
169\end{array}$ & \\
\hline $10-11$ & A & -- & Tipton aquifer & - & \\
\hline $12-4 A$ & $A$ & - & Tipton aquifer & -- & \\
\hline $12-4 B$ & A & -- & Tipton aquifer & -- & \\
\hline
\end{tabular}

1 Construction type: $P$, production well, 7-inch diameter steel casing, openhole construction; A, 6-inch diameter steel casing, open-hole construction; B, 4-inch diameter polyvinyl chloride casing and screen, drilled in 1989 . 
Water-quality samples then were collected with either a 1-L or 350-mL high-density Teflon bailer. Samples for inorganic constituents were filtered through a $0.45-\mu \mathrm{m}$ filter and stored in precleaned, pretreated plastic bottles. Samples were preserved as follows: Samples to be analyzed for cations, trace metals, and thiocyanate were treated with nitric acid; samples to be analyzed for cyanide were preserved with ascorbic acid and sodium hydroxide; samples to be analyzed for ammonia, nitrate, and nitrite were preserved with sulfuric acid; whereas anions, other sulfur species, alkalinity, and total dissolved solids required no preservatives. Samples for volatile and semivol- atile organic compounds were not filtered and were stored in precleaned amber glass bottles. Samples were kept chilled onsite and then delivered to the Western Research Institute (WRI) laboratory in Laramie, Wyo., for analysis. Samples were split and analyzed on-site by U.S. Geological Survey personnel using a portable gas chromatograph. About 5 to 10 percent of samples were duplicates analyzed by WRI. After each day's sampling or each sampling run, distilled water was poured into the bailer, then filtered, preserved, and stored in the same way as the water samples. These bailer blanks also were sent to the laboratory for analysis.

Discharge measurements were made and water-quality samples were collected at Bitter Creek upstream and downstream from the site in April and August 1989. 


\section{GEOHYDROLOGY}

Within the regional framework described in the section Description of Study Area, site-specific factors--such as lithology, the relation of aquifers to confining units and the hydrologic properties of those aquifers, and the local flow system--can be evaluated.

\section{Lithology}

The geohydrologic system in the study area consists of two aquifers and two confining units. From top to bottom, they are the Wilkins Peak confining unit, the Tipton aquifer, the Wasatch confining unit, and the Wasatch aquifer. Detailed descriptions of the lithology and water-bearing properties of each of the units follow. The descriptions are modified from those in Glover (1988, p. 6-10) and Lidstone (Lidstone and Anderson, Inc., written commun., 1989). The geohydrologic units are defined on the basis of relative permeability, and, therefore, do not coincide exactly with geologic formations and members. The relation is shown in Figure 4 .

The uppermost unit in the study area is the Wilkins Peak confining unit. This unit contains most of the Wilkins Peak Member of the Green River Formation of Eocene age. The Wilkins Peak Member is a brackish-water deposit of ancient Gosiute Lake, and consists of interbedded mudstones, marlstones, and gray-green shales with thin, discontinuous tuff and silty sandstone beds. Evaporite deposits, such as shortite (a trona mineral composed of sodium carbonate and calcium carbonate) and analcite (sodium aluminum silicate) crystals are also present and were reported in logs from wells $20,21 \mathrm{D}, 22 \mathrm{~T}$, $23 \mathrm{~T}, 25 \mathrm{~T}, 26 \mathrm{~T}, 27 \mathrm{~T}, 30 \mathrm{~T}$, and 33T. In places near the study area, the unit averages $800 \mathrm{ft}$ thick, but at site 9, much of it has been removed by erosion and the remaining unit is only $120 \mathrm{ft}$ thick.

The Wilkins Peak confining unit generally is unsaturated in the study area, although some layers were described as "moist" during well drilling in 1989. A tuff bed called the Firehole Bed yields water to wells drilled near site 12 (about one-half mile northeast of site 9). The Firehole Bed has been removed by erosion throughout most of the study area.

The Tipton aquifer lies directly beneath the Wilkins Peak confining unit. Near the site 9 retort chamber, the aquifer comprises an 8-ft section of sandstone at the base of the Wilkins Peak Member overlying a 135-ft section of the Tipton Shale Member of the Green River Formation. The configuration of the top of the Tipton aquifer is mapped in Figure 5. This part of the Tipton is described by Lidstone (Lidstone and Anderson, Inc., written commun., 1989, p. 4) as "... an interbedded sequence of brown flaky or papery shales, low grade to moderately higher grade oil shales (ranging from 5 to nearly 50 gallons per ton oil) and thin tuff beds." The richest oil shales are near the upper $50 \mathrm{ft}$ of the Tipton Shale Member; the retort experiments are conducted in this zone. 


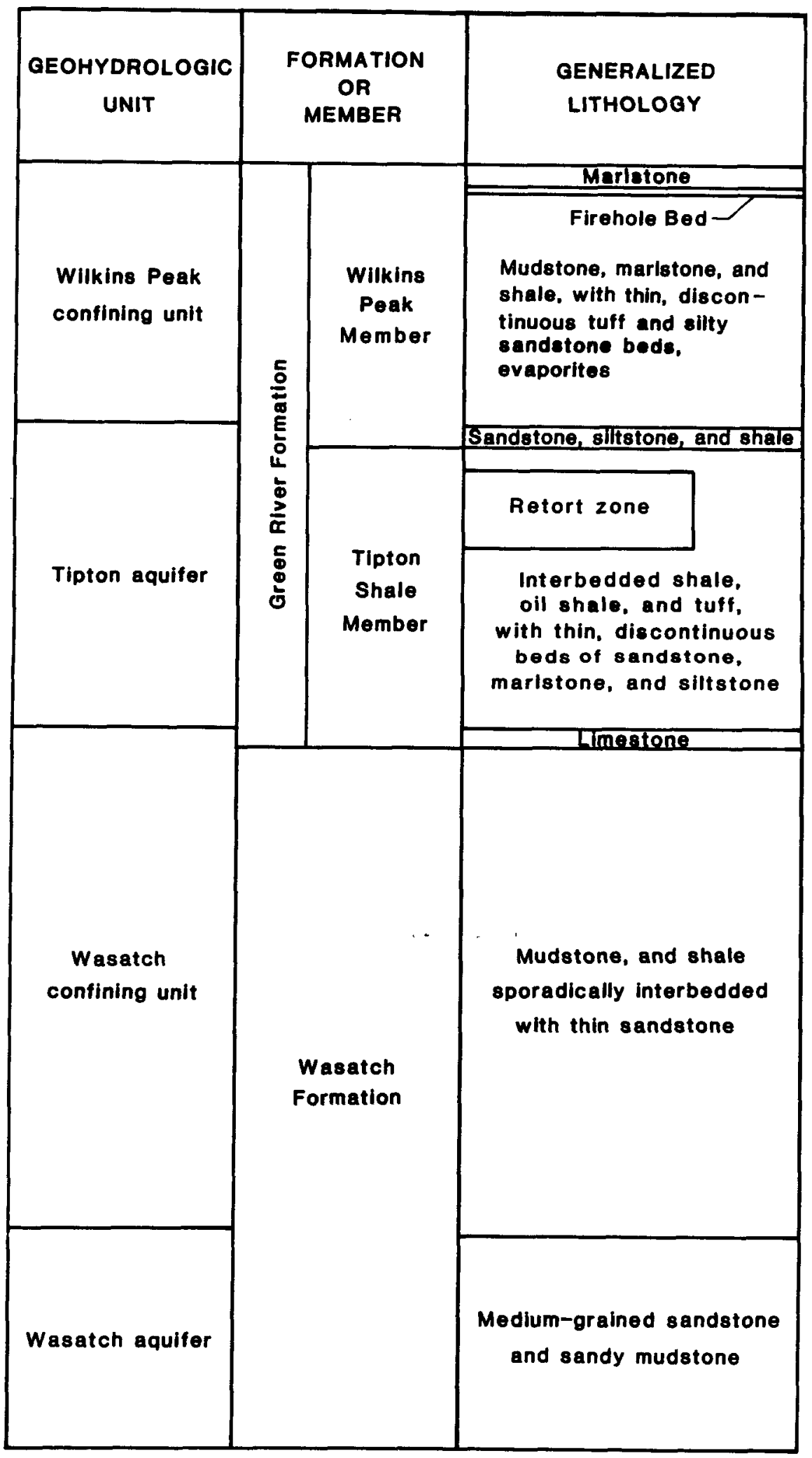

Figure 4.--Relation of geohydrologic units to geologic units at site 9 (modified from Glover, 1988, p. 4). 


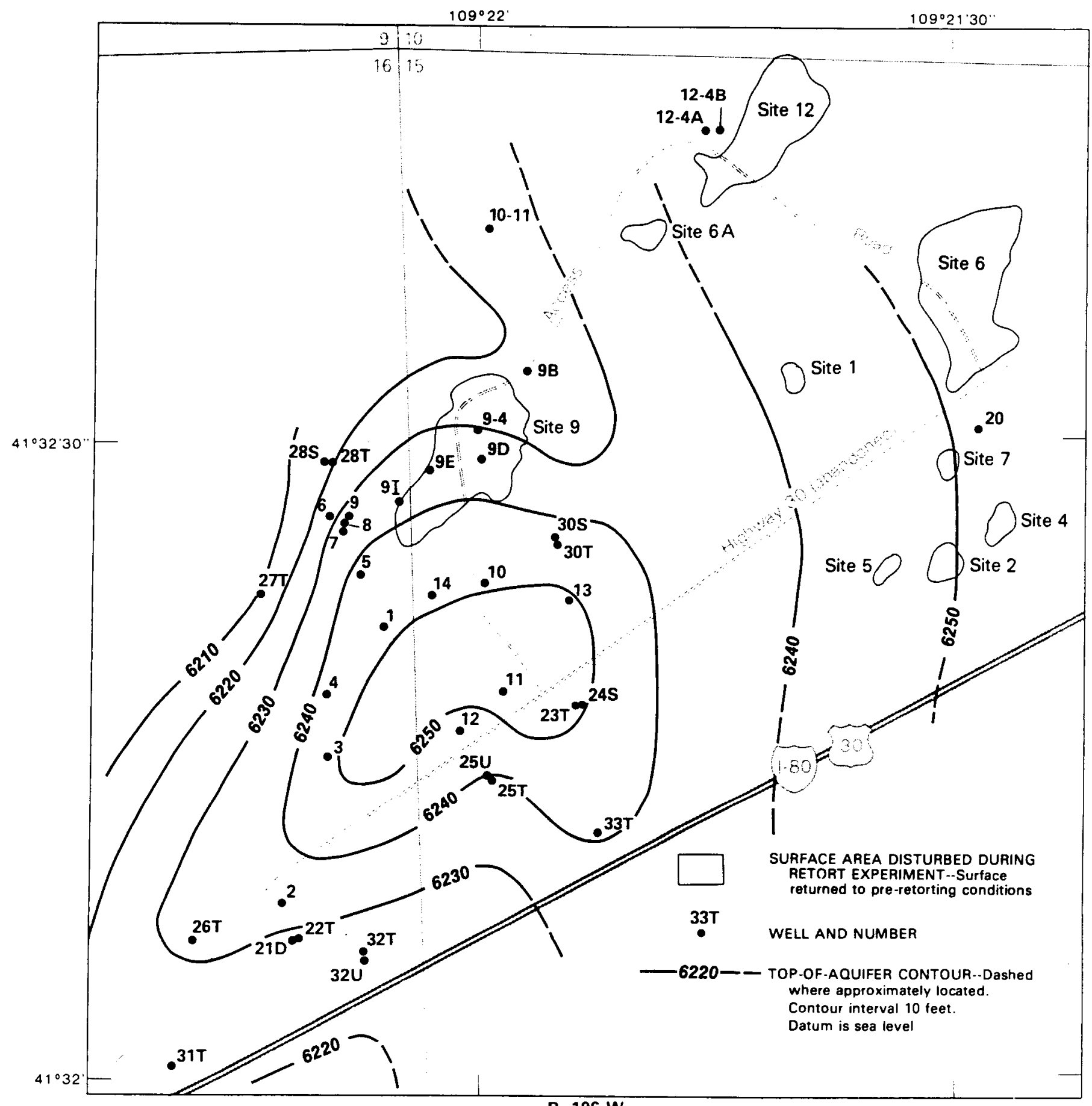

R. $106 \mathrm{~W}$.

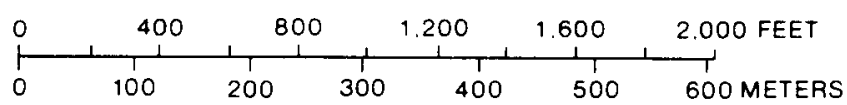

Figure 5.--Altitude and configuration of top of Tipton aquifer. 
The sandstone layer has a variable lithology. It is described as "continuous" in most of the area around site 9 that was included in Glover's study (Glover, 1988). It is well defined near well 20, but less well defined near the western side of the study area. At wells 26T, 28S, and 28T, the sandy layer was a sandy shale interbedded with siltstone (K. Laudon, Lidstone and Anderson, Inc., written commun., 1989). This westward-trending facies change also was observed in outcrops of the Wilkins Peak Member. A distinct sandstone unit was observed in a gully about $3 / 4$ mile east of site 9 , but outcrops of the sandy unit along Bitter Creek southwest of the site were much finer grained, containing primarily silt-sized material.

Lithology of that part of the Tipton Shale Member that is included in the Tipton aquifer is also variable. Discontinuous beds of sandstone, marlstone, tuff, and siltstone are present. Evaporites were reported only at well $30 \mathrm{~T}$. However, because the aquifer is saturated with water, it is not expected that evaporites would be found. Glover (1988, p. 10) states that the quality of the water in the upper part of the Tipton aquifer is consistent with what would be expected from the dissolution of trona and other evaporites.

The upper wasatch confining unit underlies the Tipton aquifer and separates it from the Wasatch aquifer. This confining unit is approximately $232 \mathrm{ft}$ thick and consists of 7-ft-thick massive limestone at the base of the Tipton Shale Member of the Green River Formation overlying $225 \mathrm{ft}$ of mudstone and shale in the upper part of the Wasatch Formation of Eocene age. The top $44 \mathrm{ft}$ of the confining unit is particularly shaley, soft, erodible, and unlikely to develop fracture or solution channels.

The basal aquifer in the study area is the Wasatch aquifer. This aquifer consists of medium-grained sandstone and sandy mudstone. The top of the aquifer is $225 \mathrm{ft}$ below the top of the Wasatch Formation. Few water wells are open to the Wasatch aquifer within the study area, but the potential exists for large-yielding wells. No evidence of secondary permeability exists, but the extensive sand facies within the aquifer indicate that the hydraulic conductivity is probably large.

\section{Hydrologic Properties of the Tipton Aquifer}

The hydrologic properties of the Tipton aquifer in the study area were evaluated during July 1989. Slug tests were used to evaluate eight wells; results of the tests are shown in Table 2 . 
Table 2.-- Aquifer test results and method of analysis

[Method of analysis: Hvorslev (1951), recovery analysis; Cooper, Cooper and others (1967) and Papadopulos and others (1973), recovery analysis. --, no measurable response. All tests were of the Tipton aquifer]

\begin{tabular}{|c|c|c|c|c|}
\hline $\begin{array}{l}\text { Well } \\
\text { num- } \\
\text { ber }\end{array}$ & $\begin{array}{c}\text { Open or screened } \\
\text { interval } \\
\text { (feet below } \\
\text { land surface) }\end{array}$ & $\begin{array}{l}\text { Method } \\
\text { of } \\
\text { analysis } \\
\end{array}$ & $\begin{array}{c}\text { Transmissivity } \\
\text { (feet squared } \\
\text { per day) }\end{array}$ & $\begin{array}{c}\text { Hydraulic } \\
\text { conductivity } \\
\text { ( feet per day) }\end{array}$ \\
\hline 3 & $80-200$ & $\begin{array}{l}\text { Hvorslev } \\
\text { Cooper }\end{array}$ & $\begin{array}{l}3.6 \\
3.8\end{array}$ & $\begin{array}{r}0.030 \\
.031\end{array}$ \\
\hline 6 & $120-200$ & $\begin{array}{l}\text { Hvorslev } \\
\text { Cooper }\end{array}$ & $\begin{array}{l}12 \\
4.2\end{array}$ & $\begin{array}{l}.16 \\
.052\end{array}$ \\
\hline 12 & $69-200$ & $\begin{array}{l}\text { Hvorslev } \\
\text { Cooper }\end{array}$ & $\begin{array}{l}70 \\
72\end{array}$ & $\begin{array}{l}.54 \\
.55\end{array}$ \\
\hline 13 & $103-200$ & $\begin{array}{l}\text { Hvorslev } \\
\text { Cooper }\end{array}$ & $\begin{array}{r}158 \\
98\end{array}$ & $\begin{array}{l}1.6 \\
1.0\end{array}$ \\
\hline $25 U$ & $60-70$ & -- & -- & -- \\
\hline $28 T$ & $155-165$ & - & -- & - \\
\hline
\end{tabular}


Eight wells-- $1,3,6,10,12,13,25 \mathrm{U}$, and $28 \mathrm{~T}$--open to the Tipton aquifer were slug tested by lowering into each well a sand-filled piece of polyvinyl chloride pipe, capped at both ends, of known length and diameter. The pipe was completely submerged in the well. The resulting displacement raised the water level; the speed of decay indicated the ability of the formation around the well to transmit water. Water-level measurements were taken every few minutes until the water level stabilized. After the water level in the well had stabilized, the pipe was quickly removed and a second set of water-level measurements were made while the water level recovered. This method of aquifer testing is useful when the aquifer transmissivity is too small for a pump test to be practical. It provides values for that part of the aquifer immediately surrounding the well, rather than integrating over a large region, as in a pump test. Data from wells 1 and 10 could not be interpreted. Tests of the other four wells were analyzed using both Hvorslev's (1951) method and the method of Cooper and others (1967) and Papadopulos and others (1973); both sets of results are shown in Table 2 for comparison.

Two wells--25U and 28T--showed no measurable response to the introduction of the pipe, which indicates the inability of the formation around the well to transmit water. The calculated values of hydraulic conductivity for the other four wells were small, ranging from 0.03 to $1.6 \mathrm{ft} / \mathrm{d}$. The values for hydraulic conductivity drived from the slug tests were greater than the

expected values for unfractured, homogeneous shale, which range from $10^{-7}$ to $10^{-3} \mathrm{ft} / \mathrm{d}$ (Heath, 1983). Either fractures or the presence of interbedded sandy or tuffaceous layers may be responsible for the increase.

In addition to primary and secondary fractures that are naturally present in the Tipton aquifer, fractures caused by the retorting process could provide conduits for ground-water flow. Fractures of various size and extent are evident in the study area, as can be seen in the areal photograph of the site (Plate 1). The area of the retort chamber (portion of the formation where shale oil was fractured or ignited) at site 9 and the extent of thermal effects of the retorting experiment are better known than the extent of the hydrofracturing. Carpenter (1988, p. 8) states that "fractures propagated from the central well to all surrounding wells," (a radius of about $200 \mathrm{ft}$ ), but Glover (1988, p. 17) believes that [induced] fracturing is not important outside of the retort chamber. At site 12, it was discovered that the effects of induced fracturing were localized because much of the explosives' energy was lost to the plasticity of the shale and tuff beds (Parrish and others, 1980). A similar process probably occurred at site 9; this mechanism may explain why Glover (1988) found low hydraulic-conductivity values away from the retort chamber. There is agreement that at site 9 , induced fracturing did not extend very far beyond the retort chamber into the formation, if at all. Thus, artificial fracturing probably did not contribute to the observed hydraulic-conductivity values that were determined during the slug tests. 


\section{Flow System}

Recharge, movement, and discharge of ground water in the study area is controlled by a small, local flow system superimposed on the regional flow system in the Tipton aquifer.

The Tipton Shale Member, which is an aquifer in the study area, is considered to be a confining unit in a regional assessment of the Green River basin (L.J. Martin, U.S. Geological Survey, written commun., 1986). Therefore, there is little information about regional movement. Except where water is moving through fractures, travel times are probably long. Overall, only small amounts of water move through the unit. Glover (1988, p. 10) proposes that water recharges the Tipton aquifer by interformational leakage in the north-central part of the Green River basin. Then the water moves laterally southward through the Tipton to the study area.

A local source of recharge for the Tipton aquifer is infiltration of precipitation that falls on White Mountain, although the arid climate in the area limits the amount of recharge available. Gullies formed by runoff are present on the sides of White Mountain, but there are no clearly defined channels in the Wilkins Peak Member at the base of the mountain, indicating that some of the water may be infiltrating the Wilkins Peak Member. The vegetation immediately at the base of the gullies on White Mountain grows more densely than most other places in the study area; this fact provides further evidence for the infiltration hypothesis. After infiltrating the Wilkins Peak Member, the water moves downward into the Tipton aquifer.

Water from wells open to the Tipton aquifer is derived from two sources: (1) Tuff or sandstone beds, and (2) bedding planes and fractures in shale. The fractures could be a relatively small number of large, discrete fractures, such as are seen on Plate 1, or a nearly uniform network of small, closely spaced fractures, or a combination of both. Very slow natural movement of water through closely spaced bedding planes and small fractures could be nearly uniform and resemble flow through a porous medium. Where large, discrete fractures occur, they could influence the direction of ground-water movement by providing a conduit for water movement. In the northern part of the study area, thick overburden and the plastic, deformable nature of the shale may have combined to squeeze many large fractures shut, since few were recorded in well logs. The quantity of water moving through unfractured rock is extremely small compared with the quantity of water moving through tuff and sandstone beds, and through bedding planes and fractures.

Generalized direction of movement of ground water through the study area is from north to south. This direction of movement can be inferred from the potentiometric surface maps of the produced zone (Figure 6 and Plate 1). There is insufficient data to draw similar maps for other zones in the Tipton aquifer. However, the direction of head gradient generally is consistent between deeper and shallower zones of the Tipton aquifer. Therefore, it is assumed that flow in other zones is parallel to flow in the produced zone. 


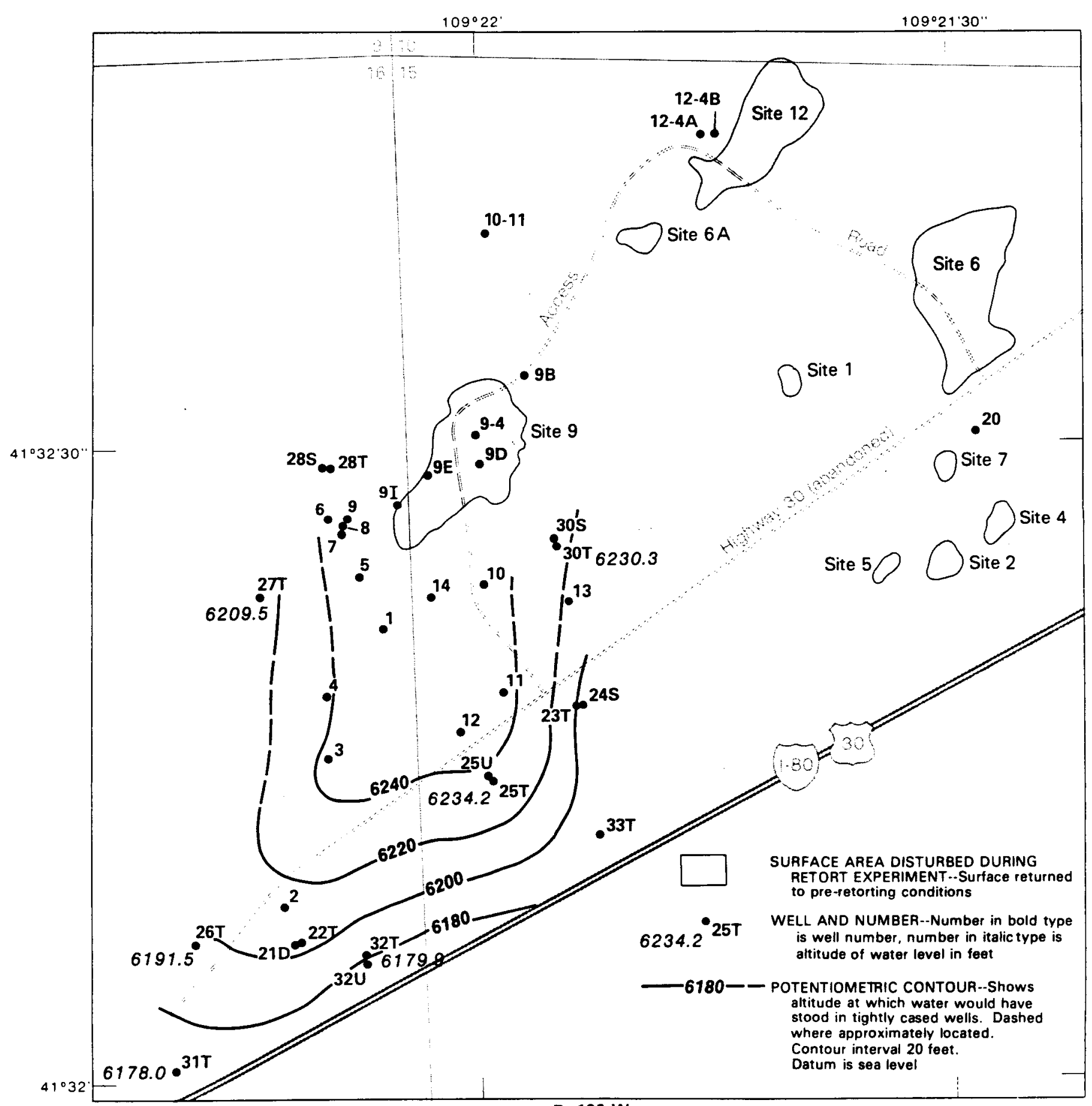

R. $106 \mathrm{~W}$.

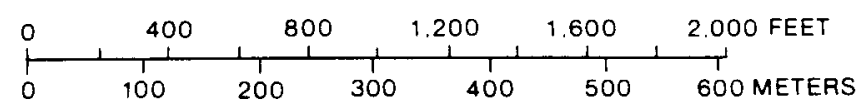

Figure 6.--Potentiometric surface for lower part of produced zone in Tipton aquifer in August 1989. 
Because the hydraulic conductivity is small, the quantity of water moving through the aquifer is small. The small horizontal conductivity in the Tipton aquifer also implies that water would flow at a very slow rate under the existing gradient, if the Tipton aquifer were of uniform composition and unfractured. The Tipton aquifer is not uniform; composition and fracture size and density vary within the aquifer. Water flows faster than is defined by the existing gradient for the site where fractures occur, in the sandstone layer, and in interbedded sandy or tuffaceous layers, and slower than is defined by the existing gradient for the site, if at all, in unfractured shale.

Water levels for selected wells are listed in Table 3. The water levels fluctuate, indicating that although the hydraulic conductivity is small, the aquifer is responding to some hydrologic stimulus such as recharge. Some apparent fluctuations may be due to water level recovery shortly after drilling; these are marked with an asterisk in Table 3 . The water levels in wells 6 through 9 generally indicate an upward gradient from the wasatch aquifer into the Tipton aquifer.

Glover's (1988, p. 17) model study indicates a vertical hydraulic conductivity four to six orders of magnitude less than the horizontal hydraulic conductivity in the Tipton aquifer. The great contrast between horizontal and vertical hydraulic conductivity may mean that water moving through the aquifer will continue to move at the same stratigraphic level. Moreover, the water may not mix readily with water deeper or shallower in the aquifer.

A downward gradient from the sandstone layer at the top of the Tipton aquifer into the lower part of the aquifer is present at paired wells $28 \mathrm{~S}$ and 28T. However, the small vertical permeability indicates that little or no vertical flow actually occurs anywhere at the site except possibly at the retort chamber. Vertical fractures described in the section "Geologic History" and visible on Plate 1 apparently do not allow vertical movement of water in most of the northern parts of the study area. Although a head difference exists at most of the paired wells, marked differences in water quality between paired wells indicate that little or no vertical flow is actually taking place. The plastic nature of the sediments in most of the Tipton aquifer and the weight of the overburden may have combined to seal fractures that were present naturally. Because the retort chamber is artificially fractured, resistance to vertical movement is less than in the surrounding undisturbed formation. Glover (1988) says that the retort chamber might act as a conduit for water to flow upward from the lower part of the Tipton aquifer into the sandstone layer. Data from paired wells $28 \mathrm{~S}$ and $28 \mathrm{~T}$, and $30 \mathrm{~S}$ and $30 \mathrm{~T}$ support this interpretation. If the retort chamber acts as a conduit, the upward gradient in paired wells $28 \mathrm{~S}$ and $28 \mathrm{~T}$, and $30 \mathrm{~S}$ and $30 \mathrm{~T}$ (except measurements in August 1989 at wells 28S and 28T) imply that upward movement is possible. 
Table 3.--Water levels at Rock Springs sites, 1975-89

[--, no data; *, indicates water level shortly after well was drilled]

\begin{tabular}{cccccccccc}
\hline & Altitude of & Open & & & & & & & \\
well casing & or & Original & \multicolumn{4}{c}{ Altitude of water level above sea level } \\
\cline { 4 - 9 } Well & above sea & screened & well & July & December & April & August September October \\
number & level & interval & depth & 1975 & 1980 & 1981 & 1981 & 1981 & 1981 \\
\hline
\end{tabular}

Altitude, interval, and depth, in feet

\begin{tabular}{|c|c|c|c|c|c|c|c|c|c|}
\hline 1 & $6,291.62$ & $95-200$ & 200 & -- & -- & -- & -- & -- & $6,222.94$ \\
\hline 2 & $6,251.25$ & $55-200$ & 200 & -- & -- & - & -- & -- & $6,201.79$ \\
\hline 3 & $6,269.74$ & $80-200$ & 200 & -- & -- & -- & -- & $6,241.44$ & $6,242.12$ \\
\hline 4 & $6,281.56$ & $112-200$ & 202 & -- & -- & -- & -- & -- & -- \\
\hline 5 & $6,301.08$ & $110-202$ & 202 & -- & -- & -- & -- & -- & -- \\
\hline 6 & $6,312.62$ & $120-200$ & 202 & -- & -- & -- & -- & -- & $6,203.57$ \\
\hline 7 & $6,321.73$ & $270-350$ & 350 & -- & -- & -- & -- & -- & $6,232.21^{*}$ \\
\hline 8 & $6,323.82$ & $350-450$ & 450 & -- & -- & -- & -- & -- & $6,261.29 *$ \\
\hline 9 & $6,323.94$ & $460-1,020$ & 1,030 & -- & -- & -- & -- & -- & $6,280.65^{*}$ \\
\hline 10 & $6,307.52$ & $90-200$ & 200 & -- & -- & -- & -- & -- & -- \\
\hline 11 & $6,284.85$ & $79-200$ & 200 & -- & -- & - & -- & -- & -- \\
\hline 12 & $6,276.20$ & $69-200$ & 200 & -- & -. & -- & -- & -- & - \\
\hline 13 & $6,304.68$ & $103-200$ & 200 & -- & -- & -- & -- & -- & -- \\
\hline 20 & $6,335.00$ & $110-120$ & 120 & -- & -- & -- & -- & -- & -- \\
\hline 210 & $6,243.13$ & $150-160$ & 160 & -- & -- & -- & -- & -- & -- \\
\hline $22 \mathrm{~T}$ & $6,243.00$ & $110-120$ & 120 & -- & -- & -- & -- & -- & - \\
\hline $23 T$ & $6,289.73$ & $130-140$ & 140 & - & -- & -- & -- & -- & -- \\
\hline $24 S$ & $6,289.83$ & $40-50$ & 50 & -- & -- & -- & -- & -- & -- \\
\hline $25 \mathrm{U}$ & $6,267.65$ & $60-70$ & 70 & -- & - & -- & -- & -- & -- \\
\hline $25 T$ & $6,268.50$ & $110-120$ & 120 & -- & -- & -- & -- & -- & -- \\
\hline $26 \mathrm{~T}$ & $6,249.06$ & $110-120$ & 120 & -- & -- & -- & -- & -- & -- \\
\hline $27 \mathrm{~T}$ & $6,298.94$ & $160-170$ & 170 & -- & -- & -- & -- & -- & -- \\
\hline $28 S$ & $6,324.89$ & $100-110$ & 110 & -- & -- & -- & -- & -- & -- \\
\hline $28 \mathrm{~T}$ & $6,325.18$ & $155-165$ & 165 & -- & -- & -. & -- & -- & -- \\
\hline $30 S$ & $6,321.89$ & $80-90$ & 90 & -- & -- & -- & -- & -- & -- \\
\hline $30 T$ & $6,321.70$ & $150-160$ & 160 & -- & -- & -- & -- & -- & -- \\
\hline $31 \mathrm{~T}$ & $6,230.71$ & $70-80$ & 80 & -- & -- & -- & -- & -- & -- \\
\hline 325 & $6,237.96$ & $50-60$ & 60 & -- & -. & -- & -- & -- & -- \\
\hline $32 \mathrm{~T}$ & $6,238.11$ & $80-90$ & 90 & -- & -. & -. & -- & -- & -- \\
\hline $33 T$ & $6,269.01$ & $110-120$ & 120 & -- & -- & -- & -- & -- & -- \\
\hline $9 B$ & $6,358.47$ & $150-206$ & 206 & $6,220.47$ & $6,226.47$ & $6,232.97$ & -- & $6,233.82$ & -- \\
\hline $9-4$ & $6,338.88$ & $135-186$ & 191 & -- & $6,223.88$ & $6,222.88$ & $6,225.08$ & $8 \quad 6,225.51$ & -- \\
\hline $10-11$ & $6,390.00$ & -- & -- & -- & -- & -- & -- & -- & -- \\
\hline
\end{tabular}


Table 3.--Water levels at Rock Springs sites, 1975-89--Continued

\begin{tabular}{|c|c|c|c|c|c|c|c|c|c|}
\hline \multirow[t]{2}{*}{ Well } & \multicolumn{9}{|c|}{ Altitude of water level above sea level } \\
\hline & December & January & March & May & March & May & June & July & August \\
\hline number & or 1981 & 1982 & 1982 & 1982 & $1988^{2}$ & 1989 & 1989 & 1989 & 1989 \\
\hline \multicolumn{10}{|c|}{ Altitude, in feet } \\
\hline 1 & $6,224.17$ & $6,222.06$ & $6,224.84$ & $6,225.11$ & $6,239.07$ & $6,234.62$ & $6,227.12$ & $6,230.80$ & -- \\
\hline 2 & $6,207.15$ & $6,208.82$ & $6,209.18$ & $6,209.38$ & -- & $6,205.25$ & $6,195.55$ & -- & - \\
\hline 3 & $6,242.58$ & $6,241.84$ & $6,240.90$ & $6,243.50$ & $6,240.99$ & $6,243.54$ & $6,242.44$ & $6,242.54$ & $6,242.06$ \\
\hline 4 & $6,236.67$ & $6,240.68$ & $6,241.87$ & $6,243.55$ & $6,240.31$ & $6,242.96$ & - & -. & -- \\
\hline 5 & 6.271 .00 & $6,271.50$ & $6,271.78$ & $6,270.83$ & $6,255.08$ & $6,258.48$ & $6,264.58$ & - & $6,257.96$ \\
\hline 6 & $6,208.99$ & $6,210.53$ & -- & $6,209.06$ & $6,211.12$ & $6,213.92$ & $6,207.42$ & $6,207.05$ & -- \\
\hline 7 & $6,275.97$ & -- & $6,245.02$ & $6,245.26$ & -- & -- & - & $6,246.27$ & - \\
\hline 8 & $6,246.88$ & -- & $6,282.53$ & $6,282.85$ & -- & -- & - & $6,282.48$ & -- \\
\hline 9 & $6,309.96$ & -- & -- & $6,313.00$ & -- & -- & -- & $6,318.54$ & \\
\hline 10 & $6,221.07$ & $6,220.30$ & $6,222.80$ & $6,223.82$ & $6,228.42$ & $6,223.32$ & $6,227.32$ & $6,227.06$ & $6,224.57$ \\
\hline 11 & $6,242.87$ & $6,242.14$ & $6,244.77$ & $6,243.80$ & - & $6,229.45$ & $6,242.55$ & -- & $6,242.21$ \\
\hline 12 & 6.243 .19 & $6,242.19$ & $6 ; 244.56$ & $6,243.96$ & -- & $6,244.50$ & $6,240.60$ & $6,242.65$ & -- \\
\hline 13 & $6,243.82$ & $6,242.94$ & $6,245.59$ & $6,244.67$ & $6,241.28$ & $6,240.78$ & $6,242.88$ & $6,242.91$ & $6,237.78$ \\
\hline $20 T$ & -- & -- & -- & -- & -- & Dry & $6,214.9$ & -- & -- \\
\hline 210 & -- & -- & -- & -- & -- & Dry* & Dry & -- & Dry \\
\hline $22 \mathrm{~T}$ & - & - & -- & -- & -- & $6,114.00$ & $6,123.60$ & -- & $6,115.06$ \\
\hline $23 T$ & -- & -- & -- & -- & -- & $6,189.73$ & $6,169.43$ & -- & $6,192.24$ \\
\hline $24 S$ & -- & - & -- & -- & - & $6,262.13$ & $6,262.13$ & -- & Dry \\
\hline $25 S$ & - & - & -- & -- & -- & $6,233.65^{\star}$ & $6,248.75$ & $6,256.49$ & $6,258.76$ \\
\hline $25 T$ & -- & -- & -- & -- & -- & $6,240.00^{\star}$ & $6,234.80$ & $6,234.38$ & $6,234.19$ \\
\hline $26 \mathrm{~T}$ & -- & -- & -- & -- & - & $6,165.06^{*}$ & $6,192.86$ & -- & $6,191.47$ \\
\hline $27 T$ & -- & -- & -- & -- & -- & $6,228.44$ & $6,208.64$ & - & $6,209.54$ \\
\hline 285 & -- & -- & -- & -- & - & $6,241.09$ & $6,234.69$ & $6,237.26$ & $6,266.87$ \\
\hline $28 \mathrm{~T}$ & -- & -- & -- & -- & -- & $6,285.58$ & $6,261.98$ & $6,270.39$ & $6,260.18$ \\
\hline $30 S$ & - & -- & -- & -- & -- & Dry & Dry & Dry & Dry \\
\hline $30 T$ & -- & -- & -- & -- & -- & -- & $6,220.20$ & - & $6,230,34$ \\
\hline $31 \mathrm{~T}$ & -- & -- & - & -- & - & $6,155.71 *$ & $6,174.41$ & -- & $6,178.00$ \\
\hline $32 \mathrm{~S}$ & -- & - & -- & -- & -- & $6,192.56^{\star}$ & $6,192.96$ & $6,194.79$ & $6,195.36$ \\
\hline $32 \mathrm{~T}$ & -- & -- & -- & -- & -- & $6,176.01 *$ & $6,179.91$ & $6,179.85$ & $6,179.91$ \\
\hline 33T & -- & -- & -- & -- & -- & $6,210.01 *$ & $6,232.21$ & $6,233.42$ & $6,233.11$ \\
\hline $9 B$ & -- & $6,257.47$ & -- & $6,232.53$ & -- & -- & $6,241.87$ & - & -- \\
\hline $9-4$ & -- & $6,221.38$ & -- & $6,221.20$ & $6,219.38$ & -- & -- & -- & $6,219.40$ \\
\hline $10-11$ & -- & -- & -- & -- & -- & $6,224.00$ & $6,223.00$ & - & $6,222.89$ \\
\hline
\end{tabular}

1 Measured by personnel from Western Research Institute and Wyoming Department of Environmental Quality (Western Research Institute, 1988). 
Discharge from the Tipton aquifer in the study area is reported to occur at seeps along outcrop areas, including road and railroad cuts, to the alluvium of Bitter Creek, or by evapotranspiration. Ponded dark water was observed in the discharge area north of Bitter Creek (SW1/4 SW1/4 SW1/4 sec. 15, T. 18 N., R. 106 W.) in May 1983 (Glover, 1988, p. 25). Between October 1988 and May 1989, U.S. Geological Survey personnel made five visits to locate dark-water discharges near Bitter Creek. Personnel from the WDEQ also were present during the May visit. No dark-water seeps or ponded dark water were observed, and it is assumed that the dark water mentioned in Glover (1988) was a transient phenomenon.

Discharge in Bitter Creek was measured and sampled at SW-1 and SW-2 (Figure 2 and Plate 1) on April 11 and August 17, 1989. Measurements made during the April visit indicated that Bitter Creek was losing streamflow in the reach between $S W-1$ and SW-2, which passes retort site 9. A third site (SW-3, Figure 2) was measured on August 17. Streamflow at SW-3 increased slightly compared to SW-2 on the same day; however, the differences in flow between the sites in August is so small that it is probably within the error of measurement. (See following Table for summary of surface-water measurements.) Bubbles were observed rising from the streambed, which was shaly at this site. The zone of the Tipton aquifer that is stratigraphically equivalent to the retort chamber appears to be at or near the surface at this site. A water-quality sample taken from this site, however, showed no organic contamination.

Summary of surface-water measurements

$[--$, data not available ]

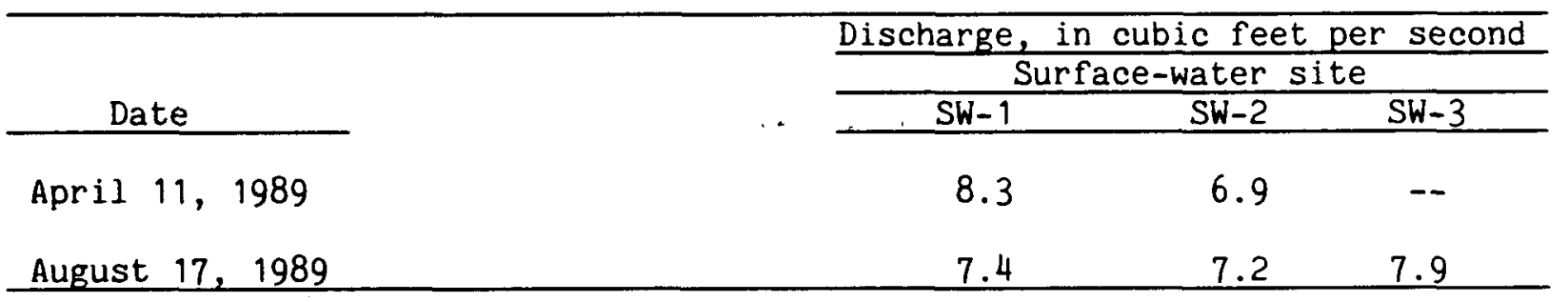

Because the hydraulic conductivity of the Tipton aquifer is small, the quantity of water discharged from the aquifer might be too small to measure reliably. Of the three mechanisms proposed for discharge, the first two (at seeps or to Bitter (reek) seem unlikely to be able to account for substantial amounts of water, based on results of this study. The most likely mechanism is the remaining one, evapotranspiration. The water that might be discharged by seepage or to Bitter Creek probably is masked by consumption by phreatophytes and evaporation. In the winter, when the evapotranspiration rate is lessened, it is possible that small amounts of water could be discharged from the Tipton aquifer by seepage or to Bitter Creek. 
Before retorting or extensive fracturing began, concentrations of many constituents exceeded USEPA drinking-water regulations. Dissolved-solids residue on evaporation was as much as $48,600 \mathrm{mg} / \mathrm{L}$ (Virgona and others, 1979, p. 15). Western Research Institute (1988), Weand (1978), and Smith and Weand (1977) describe the water as predominantly sodium bicarbonate and sodium carbonate (trona). Sodium concentrations as high as $19,700 \mathrm{mg} / \mathrm{L}$ and $\mathrm{pH}$ as high as 11 (Virgona and others, 1979, p. 15) were reported, and boron, arsenic, selenium, and mercury were detected in some samples (Virgona and others, 1979, p. 16).

The small permeability calculated for the Tipton aquifer implies that flow rates are slow. The combination of long flow paths (large distances from the recharge area) and slow flow rates result in long residence times and are responsible for the poor quality of the baseline ground water. It seems likely that slow natural movement of water through finely spaced bedding planes and small fractures is an important flow mechanism at the site, because the water appears to have had time to dissolve substantial quantities of soluble minerals from the surrounding rock. Water recharging the Tipton aquifer by downward percolation through the Wilkins Peak Member may have dissolved trona minerals in the Wilkins Peak Member, adding to the dissolved solids load.

There were large variations in water quality over short distances at the site before retorting or extensive fracturing began. Between January 1974 and June 1975, samples were collected from 18 wells open to the upper half of the Tipton aquifer located within a $0.5-\mathrm{mi}$ radius of well 9-1 (Figure 2). Data provided by DOE (U. Sharum, written commun., 1990) were analyzed to produce Table 4. The statistical format was used to provide information about the variability of the data, which spanned several orders of magnitude for some constituents; the table shows the ranges of concentration for those constituents WDEQ has requested that DOE continue to monitor at the site.

In parts of the Green River basin approximately 50 miles north of the study area, dark-colored ground water was found in samples from oil-shale zones (Phillips, 1978, p. 1; Dana and Smith, 1973, p. 153). The dark color is the result of trona water dissolving naturally occurring humic and fulvic acids in the organic matter (kerogen) in the oil shale. The dark water "... consists primarily of 5 to 8 percent organic acids and 4 to 6 percent sodium carbonate and bicarbonate dissolved in water" (Phillips, 1978, p. 1). Dissolved-solids concentrations for this water ranged from 65,550 to 140,000 $\mathrm{mg} / \mathrm{L}$ (Phillips, 1978, p. 10). Dark-colored water detected in samples from wells open to the upper half of the Tipton aquifer, particularly west and northwest of site 9 , is probably dark for the same reason. Leenheer and Noyes (1986, p. 32) report that the dissolved-organic carbon fractionation pattern for ground water from observation wells in the Tipton aquifer at site 9 is "typical for kerogen from the Green River Formation extracted by alkaline carbonate-type ground waters." 
Table 4.--Statistical summary of selected constituents and properties in water samples collected from wells open to the produced zone of the Tipton aquifer at site 9 before retorting or extensive fracturing, 1974-75

[--, insufficient data for statistical analysis; $\mu \mathrm{S} / \mathrm{cm}$, microsiemens per centimeter at 25 degrees Celsius; mg/L, milligrams per 1 iter; $\mu \mathrm{g} / \mathrm{L}$, micrograms per liter; ft, feet; <, less than. Number in parenthesis is well number where indicated minimum or maximum concentration was detected. Analysis by U.S. Geological Survey, of data provided by U.S. Department of Energy]

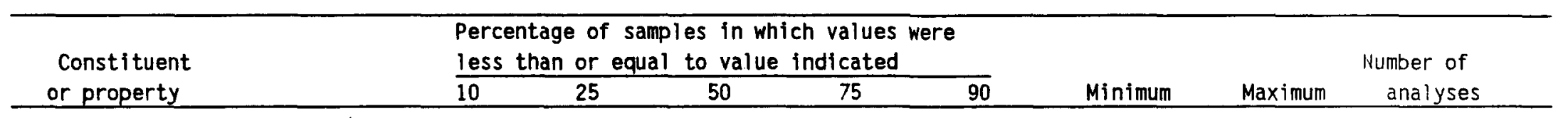

Wells 9-1 through 9-5 (Fig. 2), open to planned retort chamber at site 9

\begin{tabular}{|c|c|c|c|c|c|c|c|}
\hline Specific conductance $(\mu \mathrm{S} / \mathrm{cm})$ & 10,400 & 12,200 & 14,800 & 16,700 & 17,500 & 8,405 & 20,920 \\
\hline pH (units) & 8.7 & 9.0 & 9.1 & 9.4 & 9.8 & 8.6 & 10.3 \\
\hline Fluoride (mg/L) & 16 & 24 & 31 & 36 & 39 & 7.6 & 54 \\
\hline Bromide (mg/L) & -- & - & .45 & - & -- & .19 & $5:$ \\
\hline Dissolved solids (mg/L) & 9,900 & 11,500 & 14,200 & 15,800 & 17,500 & 7,600 & 24,600 \\
\hline Boron $(\mu \mathrm{Lg} / \mathrm{L})$ & 22 & 26 & 40 & 46 & 55 & 12 & 68 \\
\hline Chromium $(\mu \mathrm{g} / \mathrm{L})$ & -- & -- & 3 & -- & - & 1 & 38 \\
\hline Lead $(\mu g / L)$ & - & -- & 2 & -- & -- & $<1$ & 41 \\
\hline Mol ybdenum $(\mu \mathrm{g} / \mathrm{L})$ & -- & -- & 4,300 & -- & -- & 2,500 & 6,700 \\
\hline Total organic carbon $(\mu \mathrm{g} / \mathrm{L})$ & 160 & 216 & 300 & 366 & 390 & 138 & 479 \\
\hline
\end{tabular}

Wells within approximately $1,500 \mathrm{ft}$ radius of well 9-1, excluding wells 9-1 through 9-5 (Fig. 2)

\begin{tabular}{|c|c|c|c|c|c|c|c|c|}
\hline Specific conductance $(\mu \mathrm{S} / \mathrm{cm})$ & 1,036 & 3,250 & 11,600 & 20,450 & 28,780 & $790(9 \mathrm{H})$ & $33,800(98)$ & 32 \\
\hline $\mathrm{pH}$ (units) & 9.3 & 9.7 & 9.9 & 10.2 & 11.6 & $9.3(9 E, 9 C)$ & $12.7(9-01)$ & 28 \\
\hline Fluoride $(\mathrm{mg} / \mathrm{L})$ & .6 & 1.6 & 8.4 & 38 & 90 & $.4(9 \mathrm{H})$ & $123(9 F)$ & 30 \\
\hline Bromide $(\mathrm{mg} / \mathrm{L})$ & - & -- & 3.1 & -- & -- & $.4(9 C)$ & $12(9 E)$ & 5 \\
\hline Dissolved solids $(\mathrm{mg} / \mathrm{L})$ & 584 & 1,550 & 7,270 & 28,250 & 42,200 & $510(9 H)$ & $48,600(9 F)$ & 2 \\
\hline Boron $(\mu g / L)$ & 1,600 & 5,200 & 19,500 & 114,000 & 153,000 & $700(9 C)$ & $229,000(9 F)$ & 26 \\
\hline Chromium $(\mu \mathrm{g} / \mathrm{L})$ & -- & -- & 3 & -- & - & $0(9-01)$ & $32(9 F)$ & - \\
\hline Lead (ug/L) & -- & -- & 26 & -- & -- & $2(9 C)$ & $1,600(9 F)$ & $\varepsilon$ \\
\hline Molybdenum $(\mu \mathrm{g} / \mathrm{L})$ & -- & -- & 225 & -- & -- & $37(9 C)$ & $5,800(9-01)$ & . \\
\hline Total organic carbon $(\mu g / L)$ & 9.1 & 29 & 75 & 472 & 3,240 & $6(9 \mathrm{~J})$ & $4,720(91)$ & 2 \\
\hline
\end{tabular}




\section{EFFECTS OF RETORTING EXPERIMENTS ON WATER QUALITY}

The retort experiment produced water with a variety of organic and inorganic contaminants. Some of these contaminants are moving with the ground water; interactions with aquifer material or naturally occurring degradation processes appear to have removed or immobilized others.

\section{Water Produced During Retorting Experiment}

During the experiment at site 9, water was withdrawn that contained concentrations of dissolved solids of about $14,000 \mathrm{mg} / \mathrm{L}$, phenol concentrations of $64,000 \mu \mathrm{g} / \mathrm{L}$, and concentrations of nitrogen and sulfur species, arsenic, boron, cyanide, and fluoride that were from 3 to 30 times greater than the drinking-water regulations (Farrier and others, 1978, p. 89; U.S.

Environmental Protection Agency, 1986), but not necessarily greater than those in the naturally occurring water. Some of the water-quality data are uncertain because the samples were difficult to analyze. Chemical interferences produced inaccurate results, and concentrations of many constituents were greater than the recommended ranges for published methods. Fox and others (1978) and Farrier and others (1980) describe the results of the analysis of duplicate samples of this water by several laboratories. Coefficients of variation for determinations of most constituents ranged from 3 to 30 percent, but were 51 percent for phenols (Farrier and others, 1980, p. 193-194).

\section{Organic Constituents}

Water samples from 34 wells were collected and analyzed from March through July 1989; more than 70 identifiable organic compounds were detected using a combination of gas chromatography and mass spectrometry analytical methods. During August 1989, additional sampling for acetone was conducted at 6 wells, and 19 wells were sampled for azaarenes (pyridines, quinolines, and acridenes). Most of the organic contaminants--aromatic hydrocarbons, phenols, azaarenes, and aliphatic ketones--can be attributed to the retort experiment. A water sample from well 25U, downgradient from the site 9 retort area, had a sum of identified phenols concentration of $2,300 \mu \mathrm{g} / \mathrm{L}$, made up entirely of pentachlorophenol. At well $32 \mathrm{U}$, the concentration of the sum of identified ketones heavier than acetone (including compounds tentatively identified as ketones by the laboratory) was $11,180 \mu \mathrm{g} / \mathrm{L}$. 
Selected organic compounds that were identified in ground-water samples collected during 1989 are listed in Table 5. These compounds were selected for presentation because their presence was widespread in the study area, or because they were identified as being of particular concern to WDEQ

(C. Roosmagi, U.S. Department of Energy, written commun., 1990). The total number of wells at which a given compound was detected and the well at which the maximum concentration of each compound was detected are listed in Table 6; production well 9-4 was excluded from this analysis because of the high concentrations and number of contaminants detected in water samples from the retort chamber. Organic compounds detected in water samples from the three wells that had the highest total concentrations of organic constituents--wells $9-4,25 \mathrm{U}$, and $32 \mathrm{U}--$ are listed in Table 7.

Ground-water samples from some of the wells were difficult to analyze because the samples were extremely effervescent. Standard analytical procedures required these samples to be diluted to the point where effervescence was negligible. The sample for analys is of semivolatile compounds from well $28 \mathrm{~T}$ was diluted 50 times, and the samples from $25 \mathrm{U}$ and $32 \mathrm{~J}$ were diluted 250 times, causing a detection limit for some compounds as high as 13,000 $\mathrm{\mu g} / \mathrm{L}$. Therefore, some contaminants may not have been detected in these three well analyses, and the accuracy of reported concentrations is low. Selected wells were resampled during August 1989 and analyzed for azaarenes using nonstandard methods (Stuber and Leenheer, 1982; L.B. Barber and J.A. Leenheer, U.S.

Geological Survey, written commun., 1990). The method involved concentrating azaarenes from the water sample on columns of adsorbent resin and recovery by aqueous-acid elution. Analysis by gas chromatography and mass spectrometry followed. The detection limit ranged from 1 to $5 \mathrm{\mu g} / \mathrm{L}$ for these water samples. These analyses confirmed that if pyridines, quinolines, and acridines were not detected in samples taken from a well in March, May, or June (Tables 6 and 7), those compounds also were not detected in August ( $L . B$. Barber, U.S. Geological Survey, written commun., 1989).

Copies of laboratory analyses with complete lists of compounds identified, and compounds tentatively identified or unable to be identified, are included in a separate volume, "Organic and inorganic analyses of water samples from in-situ oil-shale retorting site near Rock Springs, Wyoming, 1989" (Eddy and others, 1991). This volume also includes information about detection limits, dilution factors for samples, and laboratory accuracy and precision. The total concentrations presented for unidentified compounds by Eddy and others (1991) are based on the assumption of a 1:1 instrument response. Actual concentrations could be larger or smaller than those reported if instrument response is not $1: 1$. For this reason, the concentrations can only be used to obtain a qualitative understanding of the distribution of organic compounds, rather than relied on as a definitive evaluation. This limitation particularly is appropriate to wells $25 \mathrm{U}$ and $32 \mathrm{U}$, which have large concentrations of unidentified semivolatile compounds reported. Because the August 1989 azaarene analyses were based on nonstandard methods, the results are not reported by Eddy and others (1991). 
[NA, not analyzed; --, not detected; D, value estimated, below detection limit; B, compound detected in bailer blank associated with sample, detection is probably not significant; Tr, small amount detected below reporting limit. Detection limit is determined statistically using the U.S. Environmental Protection Agency's Contract Laboratory Program. Sum of identified ketones and sum of identified phenols combines target compounds and 1 ibrary search compounds; (), indicates duplicate analysis]

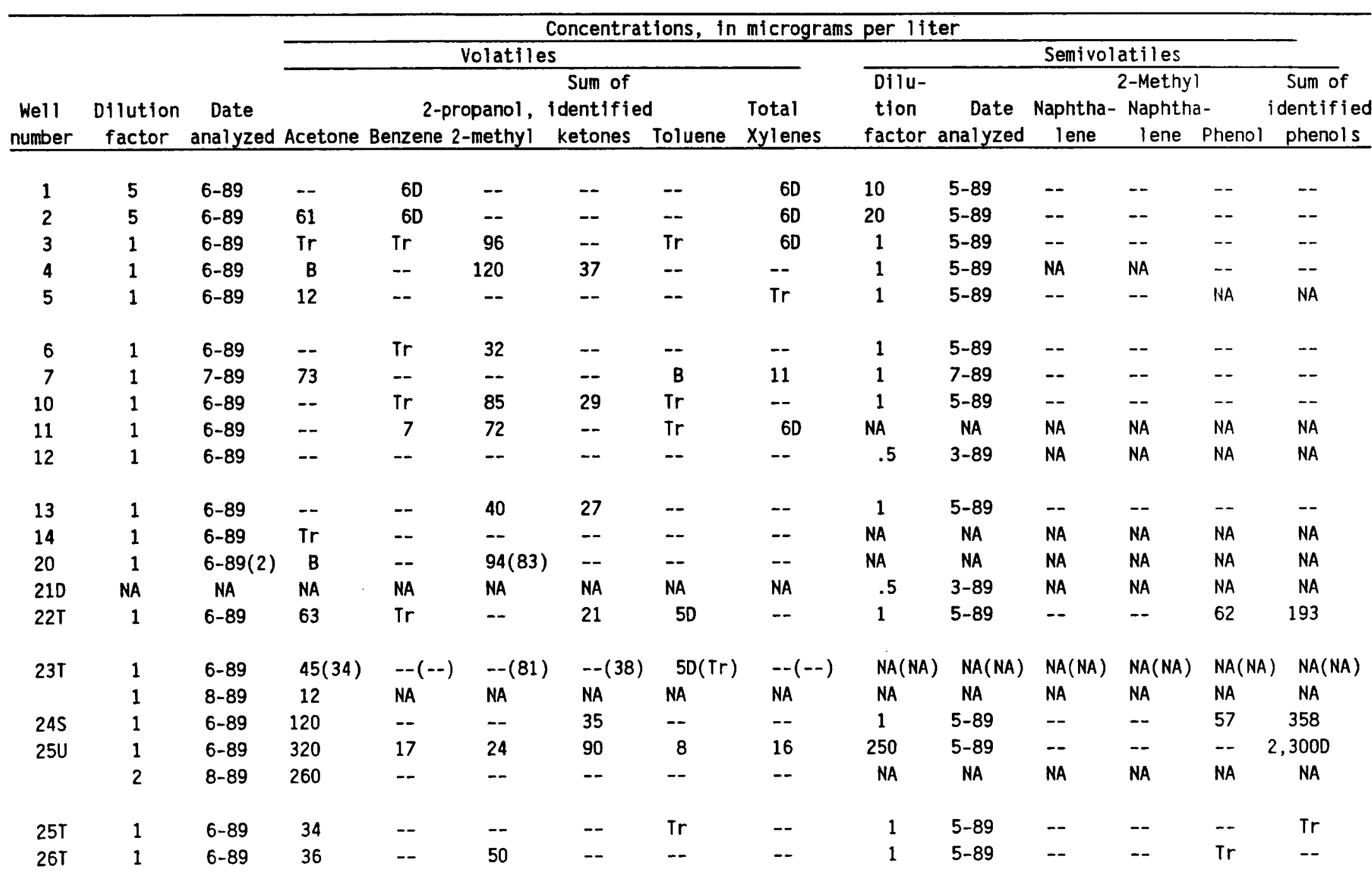


Table 5.--Selected volatile and semivolatile organic compounds detected in water samples collected from observation wells in 1989--Continued

\begin{tabular}{|c|c|c|c|c|c|c|c|c|c|c|c|c|c|c|}
\hline \multirow[b]{3}{*}{$\begin{array}{c}\text { Well } \\
\text { number }\end{array}$} & \multirow[b]{3}{*}{$\begin{array}{c}\text { Dilution } \\
\text { factor }\end{array}$} & \multicolumn{12}{|c|}{ Concentrations, in micrograms per liter } & \\
\hline & & \multirow[b]{2}{*}{$\begin{array}{c}\text { Date } \\
\text { analyzed }\end{array}$} & \multicolumn{6}{|c|}{ Volatiles } & \multicolumn{6}{|c|}{ Semivolatiles } \\
\hline & & & Acetone & Benzene & $\begin{array}{l}\text { 2-propanol, } \\
\text { 2-methyl }\end{array}$ & $\begin{array}{c}\text { Sum of } \\
\text {, identifi } \\
\text { ketones }\end{array}$ & $\begin{array}{l}\text { ied } \\
\text { Toluene }\end{array}$ & $\begin{array}{c}\text { Total } \\
\text { Xylenes }\end{array}$ & $\begin{array}{c}\text { Dilu- } \\
\text { tion } \\
\text { factor }\end{array}$ & $\begin{array}{c}\text { Date } \\
\text { analyzed }\end{array}$ & $\begin{array}{c}\text { Naphtha- } \\
\text { lene }\end{array}$ & $\begin{array}{c}\text { 2-Methyl } \\
\text { Naphtha } \\
\text { lene } \\
\end{array}$ & $\begin{array}{l}\text { a- } \\
\text { Phenol }\end{array}$ & $\begin{array}{c}\text { Sum of } \\
\text { identified } \\
\text { phenols }\end{array}$ \\
\hline \multirow[t]{2}{*}{$27 \mathrm{~T}$} & 5 & $6-89$ & 270 & -- & -- & -- & -- & $\operatorname{Tr}$ & .5 & $3-89$ & -- & -- & $\operatorname{Tr}$ & 31 \\
\hline & NA & NA & NA & NA & NA & NA & NA & NA & 1 & $5-89$ & -- & -- & -- & -- \\
\hline \multirow[t]{2}{*}{285} & 5 & $6-89$ & $110^{\circ}$ & 8D & -- & -- & 130 & 26 & 1 & $5-89$ & -- & -- & -- & $\operatorname{Tr}$ \\
\hline & 2 & $8-89$ & 30 & -- & -- & -- & -- & - & NA & NA & NA & NA & NA & $N A$ \\
\hline \multirow[t]{2}{*}{$28 \mathrm{~T}$} & 5 & $6-89$ & 68 & $\mathrm{Tr}$ & -- & -- & -- & -- & .5 & $3-89$ & NA & NA & NA & $N A$ \\
\hline & NA & NA & $N A$ & NA & NA & NA & NA & NA & 50 & $5-89$ & -- & -- & -- & -- \\
\hline $30 \mathrm{~T}$ & 1 & $6-89$ & 130 & $\mathrm{Tr}$ & -- & 66 & $\operatorname{Tr}$ & -- & .5 & $3-89$ & NA & NA & NA & NA \\
\hline $31 T$ & 1 & $6-89$ & 18 & -- & -- & 31 & -- & -- & 1 & $5-89$ & -- & -- & -- & -- \\
\hline \multirow[t]{2}{*}{$32 U$} & 5 & $6-89$ & 980 & -- & 58 & 11,180 & -- & -- & 250 & $5-89$ & -- & -- & - & -- \\
\hline & 1 & $8-89$ & 270 & NA & NA & NA & NA & NA & NA & NA & NA & NA & NA & NA \\
\hline \multirow[t]{2}{*}{$32 \mathrm{~T}$} & 2 & $6-89$ & 330 & -- & -- & 20 & -- & -- & 1 & $5-89$ & -- & -- & -- & $\mathrm{Tr}$ \\
\hline & 1 & $8-89$ & 39 & NA & NA & NA & NA & NA & NA & NA & NA & NA & NA & NA \\
\hline $33 T$ & 1 & $6-89$ & 54 & -- & 59 & -- & -- & -- & 1 & $5-89$ & -- & -- & -- & -- \\
\hline $9 B$ & 1 & $6-89$ & 13 & $6 D$ & -- & -- & -- & -- & 1 & $5-89$ & -- & -- & -- & -- \\
\hline $9 E$ & 1 & $6-89$ & 14 & -- & 49 & -- & -- & $\operatorname{Tr}$ & NA & NA & NA & NA & NA & NA \\
\hline 91 & 5 & $6-89$ & -- & -- & 38 & 56 & -- & -- & 1 & 5-89 & -- & -- & - & -- \\
\hline \multirow[t]{2}{*}{$9-4$} & 20 & $5-89$ & -- & 1,300 & -- & 933 & 520 & 480 & 5 & $5-89$ & 720 & 150 & -- & 2,990 \\
\hline & 5 & $8-89$ & 120 & NA & NA & NA & NA & NA & NA & NA & NA & NA & NA & NA \\
\hline $10-11$ & 1 & $6-89$ & $B$ & -- & - & -- & $\mathrm{Tr}$ & -- & NA & $N A$ & NA & NA & NA & NA \\
\hline $12-4 B$ & 1 & $7-89$ & -- & -- & - & -- & -- & -- & 1 & $7-89$ & -- & -- & -- & -- \\
\hline
\end{tabular}




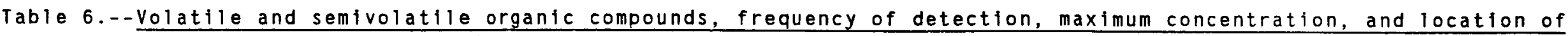
maximum occurrence in water samples collected from observation wells (excluding well $9-4$ ) in 1989

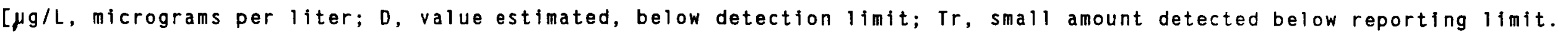

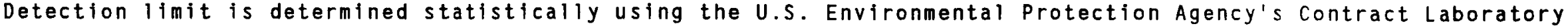
program. T, targeted compound; L, compound identified with library search, therefore value is estimated]

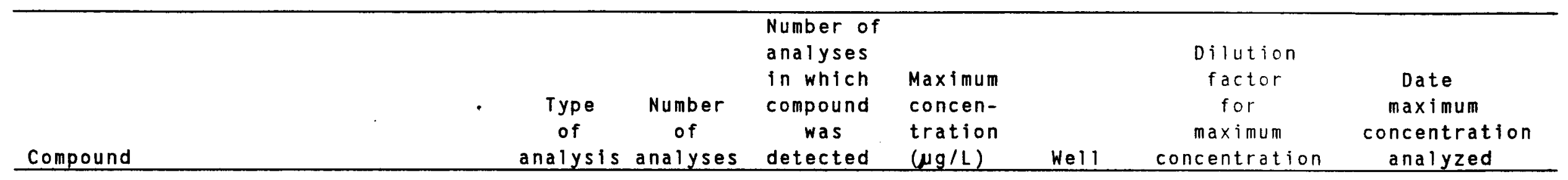

\section{Acetone}

\section{Benzene}

Bromomethane

Chloroethane

Chloromethane

Cyclohexane, 1, 1,3 trimethyl

Ethanamine, $\mathrm{N}-m e t h y 1$

Ethylbenzene

2-Heptanone

\section{4-Heptanone}

2-Heptanone, 6-methyl

4-Methyl-2-pentanone

Methylene chloride

2-Propanol

2-Propanol, 2-methy 1

Thiophene, tetrahydro

Toluene

Vinyl chloride

Total Xylenes

\section{Volatiles}

$\mathrm{T}$

$\mathrm{T}$

$T$

$T$

T

L

L

$T$

L

L

$T$

L

L

L

28
13
1
7
1
1
1
1
7
3
1
4
2
16
8
17
1
13
1
10

$\begin{array}{cc}980 & 32 \mathrm{U} \\ 17 & 25 \mathrm{U} \\ 11 & 5 \\ 180 & 32 \mathrm{U} \\ 20 & 5 \\ & \\ 22 & 5 \\ 47 & 28 \mathrm{~S} \\ 14 & 31 \mathrm{~T} \\ \mathrm{Tr} & 26 \mathrm{~T} \\ \mathrm{Tr} & 23 \mathrm{~T} \\ & \\ \mathrm{Tr} & 30 \mathrm{~T} \\ 12 & 30 \mathrm{~T} \\ 12 & 22 \mathrm{~T} \\ 24 & 10-11 \\ 500 & 27 \mathrm{~T} \\ & \\ 120 & 4 \\ \mathrm{Tr} & 25 \mathrm{U} \\ 130 & 28 \mathrm{~S} \\ 30 & 5 \\ 26 & 28 \mathrm{~S}\end{array}$

$6-89$

6-89

$6-89$

$6-89$

6-89

$6-89$

$6-89$

$6-89$

$6-89$

$6-89$

$6-89$

$6-89$

$6-89$

6-89

6-89

$6-89$

$6-89$

$6-89$

$6-89$

6-89 


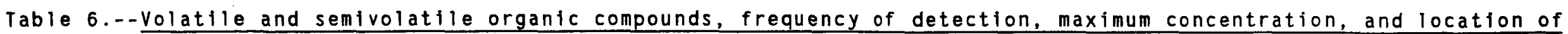
maximum occurrence in water samples collected from observation wells (excluding well 9-4) in $1989--$ continued

\begin{tabular}{|c|c|c|c|c|c|c|c|}
\hline & & & Number of & & & & \\
\hline & & & analyses & & & Dilution & \\
\hline & & & in which & Maximum & & factor & Date \\
\hline & Type & Number & compound & concen- & & for & maximum \\
\hline & of & of & was & tration & & maximum & concentration \\
\hline Compound & analysis & analyses & detected & $(\mu \mathrm{g} / \mathrm{L})$ & Well & concentration & analyzed \\
\hline
\end{tabular}

w beta-citronelle

Semivolatiles

Bicyclo $[4,1,0]$ heptane, $3-$ methyl

$1-b i s(2-E t h y l$ hexyl)Phthalate

Butanoic acid,3,3-dimethyl

Cycloheptanone

Benzal dehyde, 5-chloro-2-hydroxy

Benzenesulfan 11 imide, $\mathrm{N}$-ethyl-4-methyl

Benzoic acid

1-H-Benzotrizole

Benzyl alcohol

Cyclohexane, 1-methy 1,2-propy 1

Cyclohexano 1, 5-methy 1-2(1-methylethyl)

2-Cyclohexen-1-one, 4, 4,6-trimethy 1

cyclopentancarbonic acid,3-methy 1

Cyclopentanone, 2 -ethyl

Decanedioic acid

Decanoic acid

Trans-1,6-dimethylbicyclo[4.3.0]nonan

2,4-Dimethylphenol

$\begin{array}{ll}\mathrm{L} & 25 \\ \mathrm{~L} & 25 \\ \mathrm{~T} & 23 \\ \mathrm{~L} & 25 \\ \mathrm{~T} & 25 \\ \mathrm{~L} & \\ \mathrm{~L} & 25 \\ \mathrm{~L} & 25 \\ \mathrm{~L} & 25 \\ \mathrm{~L} & 25 \\ & 25 \\ \mathrm{~L} & \\ \mathrm{~L} & 25 \\ \mathrm{~L} & 25 \\ \mathrm{~L} & 34 \\ \mathrm{~L} & 25 \\ & 25 \\ \mathrm{~L} & 25 \\ \mathrm{~L} & 25 \\ \mathrm{~L} & 25 \\ \mathrm{~T} & 25\end{array}$

3
2
3
2
1

2
1
16
2
2
1
1
3
1
1
1
1
1
2

31
23
530
37
$\mathrm{Tr}$
100
12
$\mathrm{Tr}$
34
14
18
36
21
11
$\mathrm{Tr}$

100
250
11
21

$22 \mathrm{~T}$
$23 \mathrm{~T}$
$32 \mathrm{U}$
$31 \mathrm{~T}$
$22 \mathrm{~T}$
1
$22 \mathrm{~T}$
6,10
6
4
3
$25 \mathrm{~T}$
$23 \mathrm{~T}$
3
$31 \mathrm{~T}$
$28 \mathrm{~T}$
$28 \mathrm{~T}$
3
$23 \mathrm{~T}$

$5-89$

$5-89$

$5-89$

$5-89$

$5-89$

$5-89$

$5-89$

5-89

$5-89$

5-89

$5-89$

$5-89$

5-89

5-89

5-89

5-89

5-89

5-89 
Table 6.--Volatile and semivolatile organic compounds, frequency of detection, maximum concentration, and location of maximum occurrence in water samples collected from observation wells (excluding well 9-4) in 1989--Continued

\begin{tabular}{|c|c|c|c|c|c|c|c|}
\hline Compound & $\begin{array}{c}\text { Type } \\
\text { of } \\
\text { analysis }\end{array}$ & $\begin{array}{c}\text { Number } \\
\text { of } \\
\text { analyses }\end{array}$ & $\begin{array}{c}\text { Number of } \\
\text { analyses } \\
\text { in which } \\
\text { compound } \\
\text { was } \\
\text { detected }\end{array}$ & $\begin{array}{l}\text { Maximum } \\
\text { concen- } \\
\text { tration } \\
(\mu g / L)\end{array}$ & Well & $\begin{array}{c}\text { Dilution } \\
\text { factor } \\
\text { for } \\
\text { maximum } \\
\text { concentration }\end{array}$ & $\begin{array}{c}\text { Date } \\
\text { maximum } \\
\text { concentration } \\
\text { analyzed }\end{array}$ \\
\hline
\end{tabular}

Di-n-butylphthalate

Dodecanoic acid

Ethanol, 2-butoxy

2(3H) -Furanone, dihydro-5-methy 1

Furanone, dihydro-5-propy 1

2,5-Furandione, 3-ethy 1,4 -methyl

3-Heptene, 4-ethy ?

1-Heptene, 5 -methy 1

4-Hepten-2-0

5-Hepten-1-01,2,6-dimethy 1

2-Heptenol, 2-methyl

Hexanoic acid

1-Hexanol,2-ethyl

2-Hexanol, 2-ethyl

2-H-Indol,2-one, 1,3 dihydro

I sophorone

4-Methylphenol

3-Methylpyridine

4 -Methylpyridine

6-octen-2-one

\section{Semivolatiles--Continued}

$\begin{array}{ll}\mathrm{T} & 25 \\ \mathrm{~L} & 25 \\ \mathrm{~L} & 25 \\ \mathrm{~L} & 25 \\ \mathrm{~L} & 34 \\ \mathrm{~L} & \\ \mathrm{~L} & 25 \\ \mathrm{~L} & 25 \\ \mathrm{~L} & 25 \\ \mathrm{~L} & 25 \\ & 25 \\ \mathrm{~L} & \\ \mathrm{~L} & 25 \\ \mathrm{~L} & 25 \\ \mathrm{~L} & 25 \\ \mathrm{~L} & 25 \\ \mathrm{~T} & 25 \\ \mathrm{~T} & 25 \\ \mathrm{~T} & 23 \\ \mathrm{~T} & 28 \\ \mathrm{~L} & 28 \\ \mathrm{~L} & 25\end{array}$

$5-89$

$5-89$

$5-89$

$5-89$

$5-89$

5-89

5-89

5-89

5-89

5-89

5- 89

5-89

5-89

5-89

5-89

5-89

5-89

5-89

5-89

5-89 
Table 6.--Volatile and semivolatile organic compounds, frequency of detection, maximum concentration, and location of maximum occurrence in water samples collected from observation wells (excluding well 9-4) in 1989--Continued

\begin{tabular}{|c|c|c|c|c|c|c|c|}
\hline Compound & $\begin{array}{c}\text { Type } \\
\text { of } \\
\text { analysis }\end{array}$ & $\begin{array}{c}\text { Number } \\
\text { of } \\
\text { analyses }\end{array}$ & $\begin{array}{l}\text { Number of } \\
\text { analyses } \\
\text { in which } \\
\text { compound } \\
\text { was } \\
\text { detected }\end{array}$ & $\begin{array}{l}\text { Maximum } \\
\text { concen- } \\
\text { tration } \\
(\mu g / L)\end{array}$ & Well & $\begin{array}{c}\text { Dilution } \\
\text { factor } \\
\text { for } \\
\text { maximum } \\
\text { concentration }\end{array}$ & $\begin{array}{c}\text { Date } \\
\text { maximum } \\
\text { concentration } \\
\text { analyzed }\end{array}$ \\
\hline
\end{tabular}

\section{7-octen-2-one}

Oxirane, 2(1,1-dimethylethyl)-3-methyl

7-0xybicyclo[4.1.0]heptane

Pentachlorophenol

Pentanolc acid

Semivolatiles--Continued

$\omega_{\infty}$ Phenol

Pyrene

Pyridine

Quinoline, decahydro-1-methyl

2, 4,6-Trimethylpyridine

$\begin{array}{rrrrr}\mathrm{L} & 25 & 2 & 23 & 4 \\ \mathrm{~L} & 25 & 1 & 210 & 25 \mathrm{~T} \\ \mathrm{~L} & 25 & 1 & \mathrm{Tr} & 4 \\ \mathrm{~T} & 23 & 2 & 2,300 \mathrm{D} & 25 \mathrm{U} \\ \mathrm{L} & 25 & 1 & 29,000 & 32 \mathrm{U} \\ & & & & \\ \mathrm{T} & 24 & 4 & 62 & 22 \mathrm{~T} \\ \mathrm{~T} & 23 & 1 & \mathrm{Tr} & 28 \mathrm{~S} \\ \mathrm{~T} & 28 & 2 & \mathrm{Tr} & 23 \mathrm{~T} \\ \mathrm{~L} & 25 & 1 & 150 & 2 \\ \mathrm{~T} & 28 & 3 & \mathrm{Tr} & 9-\mathrm{B}\end{array}$

$5-89$

$5-89$

$5-89$

$5-89$

$5-89$

$5-89$

$5-89$

$5-89$

$5-89$ 
Table 7.--Organic compounds detected in water samples collected from wells $9-4,25 \mathrm{U}$, and $32 \mathrm{U}$ in 1989

[--, not detected; $D$, value estimated, below detection limit; $\mathrm{Tr}$, small amount detected below reporting limit. Detection limit is determined statistically using the U.S. Environmental Protection Agency's Contract Laboratory Program]

\begin{tabular}{cccc}
\hline & \multicolumn{3}{c}{ Concentration, } \\
\cline { 2 - 4 } Compound name & Well & Well & Well \\
& $9-4$ & $25 U$ & $32 U$ \\
\hline
\end{tabular}

\section{$\underline{\text { Volatiles }}$}

Targeted compounds:

Dilution factor:

$\begin{array}{rrr}20 & 1 & 5 \\ 5-89 & 6-89 & 6-89 \\ -- & 320 & 980 \\ 1,300 & 17 & -- \\ -- & 82 & 180 \\ 590 & \mathrm{Tr} & -- \\ 520 & 8 & -- \\ 480 & 16 & --\end{array}$

Dilution factor:

Date sampled or analyzed:

$\begin{array}{rrr}5 & 2 & 1 \\ 8-89 & 8-89 & 8-89 \\ 120 & 260 & 270\end{array}$

Acetone

.

Tentatively identified with library search:

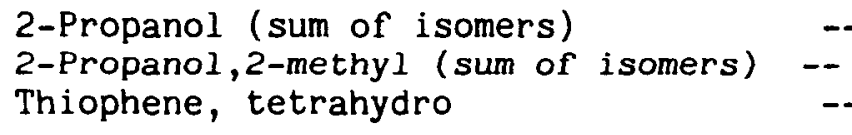

23
24
$\operatorname{Tr}$

$58^{--}$

Not identified:

(Number in square brackets following value is number of distinct compounds detected in analysis)

Total unidentified volatiles Number of distinct volatiles

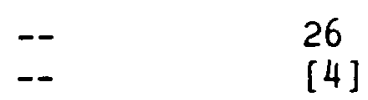

[4]
51<smiles>[AlH2]</smiles> 
Table 7.--Organic compounds detected in water samples collected from wells 9-4, 25U, and $32 \mathrm{U}$ in 1989--Continued

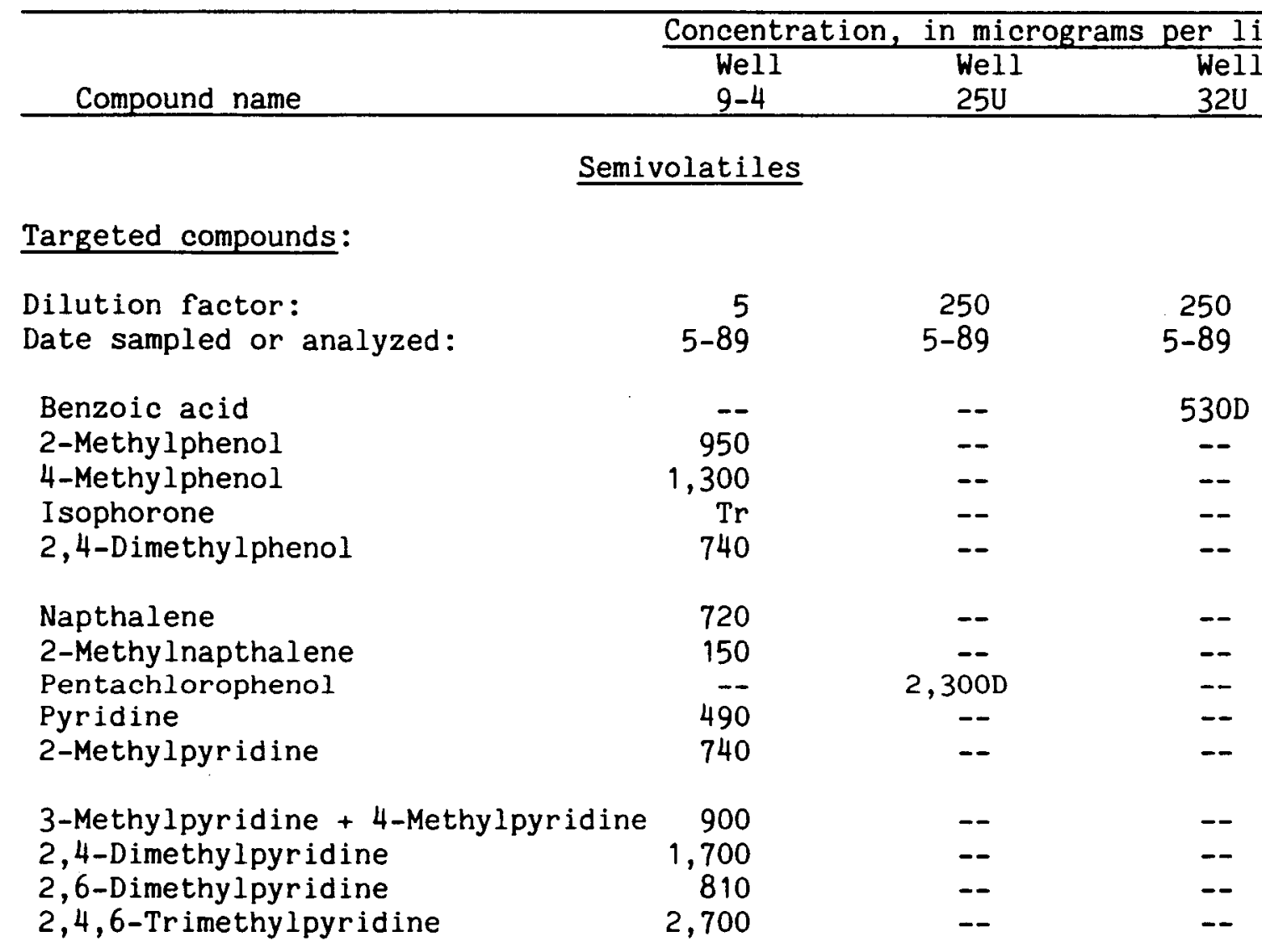

Tentatively identified with library searrch:

Cyclohexanone, 2,2,6-trimethyl 280

2 (3H)-Furanone, dihydro, 5-methyl

Hexanoic acid (sum of isomers

Pentanoic acid (sum of isomers)

3,4-Dimethylphenol

3, 4,6-Trimethylphenol

2-Ethyl, 5-methylphenol

2-Methylpyridine

2,4-Dime thylpyridine

2,6-Dimethylpyridine

2,3,5-Trimethylpyridine

2-Ethy 1, 4,6-dimethylpyridine

3-Ethyl, 2,6-dimethylpyridine

2-Methylquinol ine

2,4-Dimethylquinoline
280

$--$

290

120

220

240

730

230

390

1,000

300

230

240
8

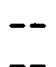

$-$

$-$

$-$

$-$

$-$

$-$

$\because$

$-$

$-$

$-$

$-$

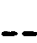

11,000

65,000

29,000 
Table 7.--Organic compounds detected in water samples collected from wells $9-4,25 \mathrm{U}$, and $32 \mathrm{U}$ in 1989--Continued

\begin{tabular}{|c|c|c|c|}
\hline Compound name & $\begin{array}{c}\text { Concent } \\
\text { Well } \\
9-4\end{array}$ & $\begin{array}{r}\text { in mic } \\
\text { Well } \\
25 \mathrm{U}\end{array}$ & $\begin{array}{c}\text { rams per liter } \\
\text { Well } \\
32 U \\
\end{array}$ \\
\hline \multicolumn{4}{|c|}{ Semivolatiles--Continued } \\
\hline $\begin{array}{l}2,6 \text {-D imethy lquinol ine } \\
2,7-\text { Dimethylquinol ine } \\
1,2,4-T r \text { ithiolane }\end{array}$ & $\begin{array}{r}150 \\
180 \\
1,100\end{array}$ & $\begin{array}{l}-- \\
--\end{array}$ & $\begin{array}{l}-- \\
-- \\
--\end{array}$ \\
\hline \multicolumn{4}{|l|}{ Not identified: } \\
\hline \multicolumn{4}{|c|}{$\begin{array}{l}\text { (Number in square brackets following value is number of distinct compounds } \\
\text { detected in analysis) }\end{array}$} \\
\hline $\begin{array}{l}\text { Total unidentified semivolatiles } \\
\text { Number of distinct semivolatiles }\end{array}$ & $\begin{array}{l}940 \\
{[5]}\end{array}$ & $\begin{array}{r}210,000 \\
{[20]}\end{array}$ & $\begin{array}{r}590,000 \\
{[16]}\end{array}$ \\
\hline
\end{tabular}


Areal distribution of acetone, the sum of all other ketones excluding acetone (including those tentatively identified by the laboratory as ketones), benzene, sum of identified phenols, total xylenes, and 2-propanol,2-methyl is shown in Figures 7 through 12. Three cross sections, whose locations are shown in Figure 13, are drawn through the area. The vertical distribution of the compounds presented in Figures 7 through 12 is depicted in Figures 14 through 16. These compounds were chosen for map presentation because they were detected in several wells throughout the study area. Many of the other contaminants were found only in a few wells (Table 6).

The distribution of constituents mapped in Figures 7 through 12 are not uniform because processes affecting the contaminants are varied. The areal and vertical distribution of organic compounds in ground water in the Tipton aquifer is affected by the following: (1) the areally variable water quality present at the site before retorting began, and the localized presence of kerogen from which organic acids could be dissolved; (2) conservative movement as compounds are transported by ground-water movement; (3) nonconservative processes affecting the compounds, including sorption onto clays and organic material in the shale, biodegradation, and interaction of organic compounds with inorganic compounds present in the water at high pH to form stable, nonsoluble compounds; and (4) combinations of the above. Movement of each compound could be expected to be affected by different combinations of these processes.

Acetone is found in many of the wells and is generally found in greater concentrations in wells screened in the shallow sandstone layer than in wells screened deeper in the aquifer (Figures 7 and 14 through 16). Many of the wells in and near the retort chamber also had low concentrations of acetone or no acetone detected, possibly because some of the acetone was flushed naturally from the retort area. Another possibility is that the wells near the retort area are all completed as open hole, and samples from these wells represent mixtures of water from different depths in the aquifer, thus diluting acetone concentrations detected primarily in the shallow portion of the aquifer. Still a third possibility is that the acetone was produced and dispersed in the gas phase during the retort experiment. Some acetone probably was lost to the atmosphere; the rest then recondensed into the ground water so its distribution is independent of the ground-water flow system. Distinguishing among these possible mechanisms is beyond the scope of this study.

The heavier ketones are not as widely distributed as acetone, nor are they concentrated more in the uppermost sandstone in the Tipton aquifer than in the deeper parts of the aquifer. This may be because, unlike acetone, the heavier ketones would not have traveled in the gas phase. 


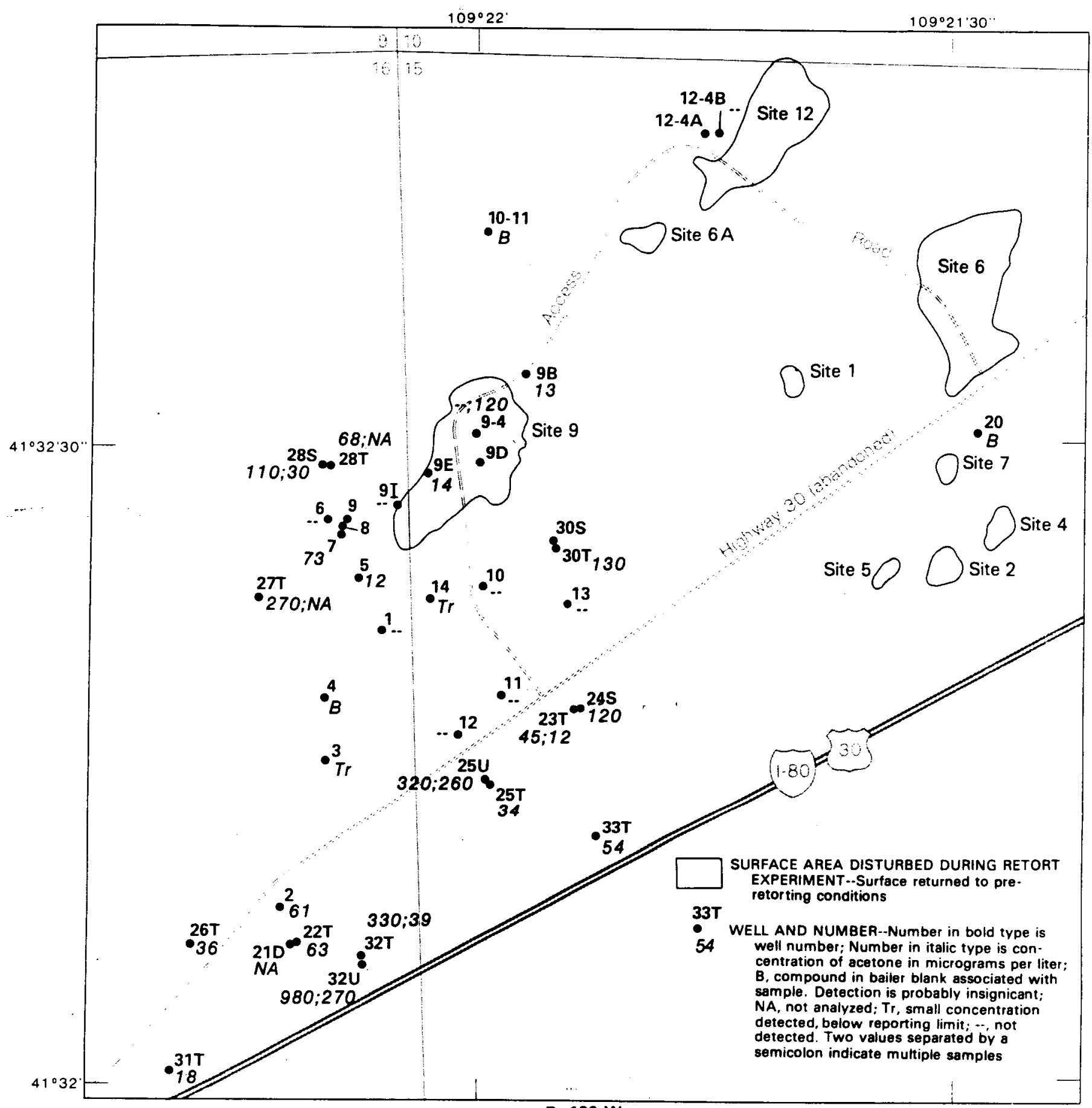

R. 106 W.

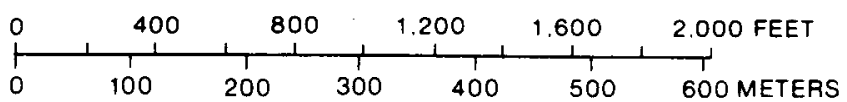

Figure 7.--Areal distribution of acetone concentrations analyzed in 1989. 


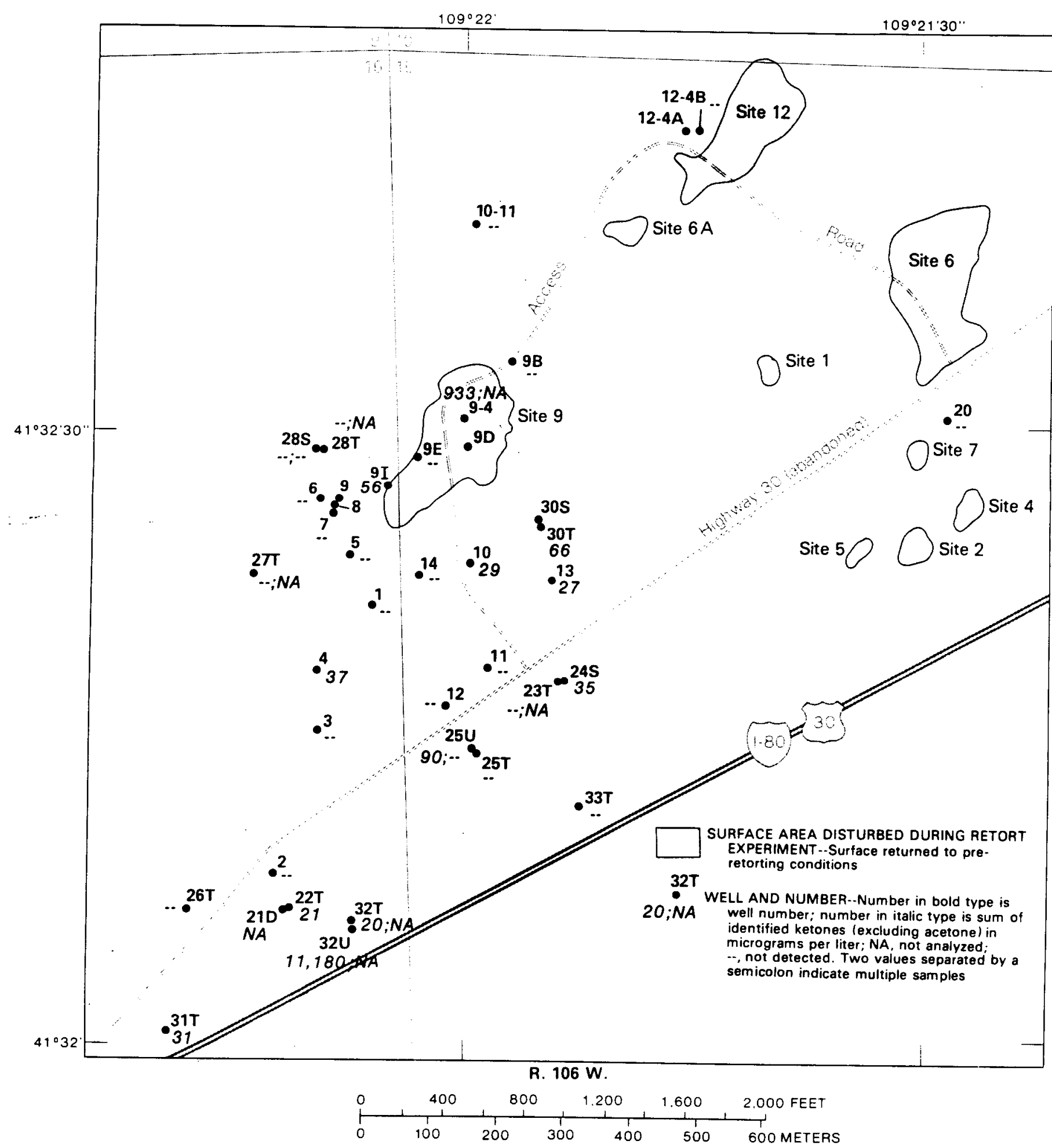

Figure 8.--Areal distribution of sum of identified ketones (excluding acetone) analyzed in 1989. 


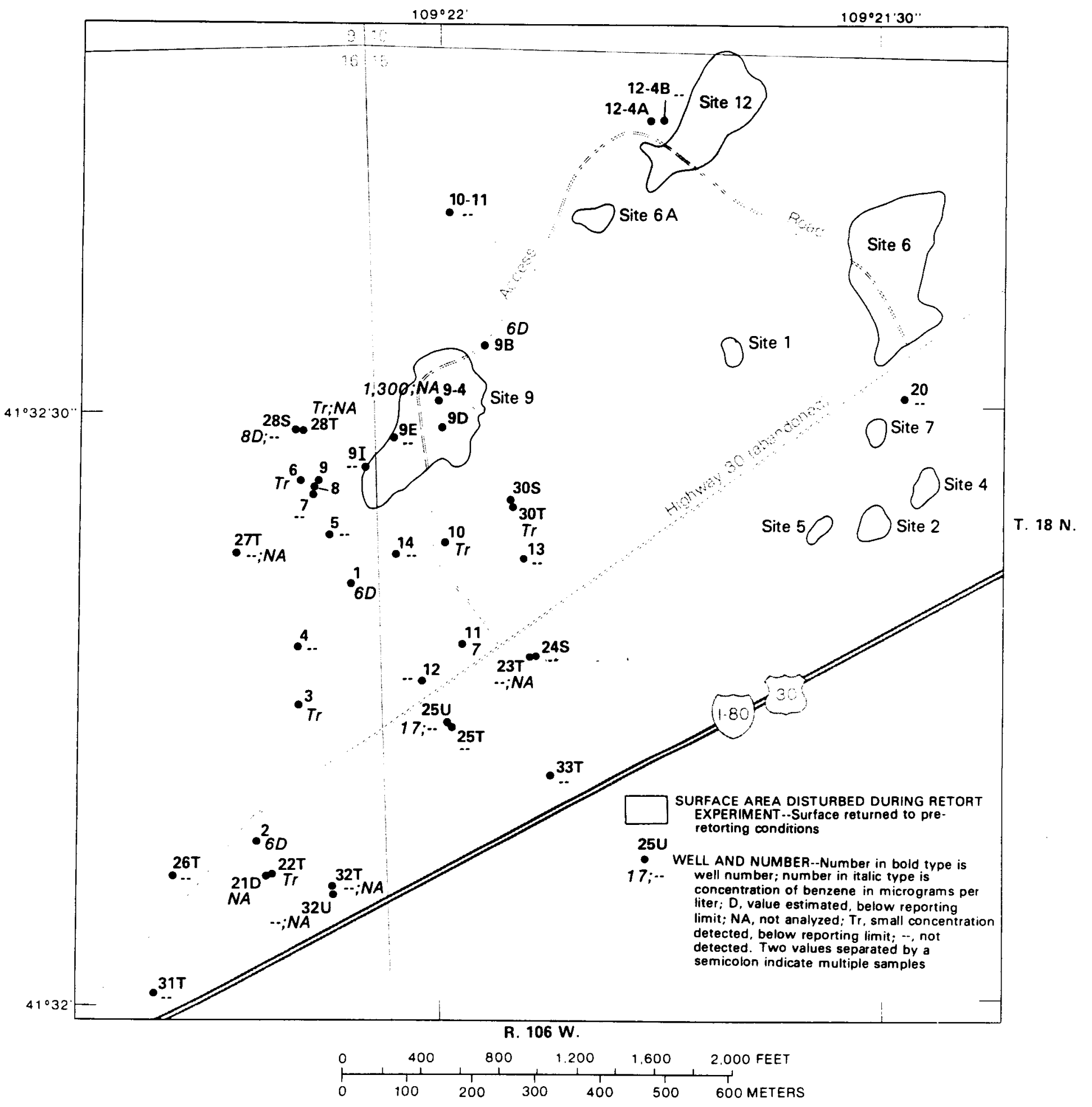

Figure 9.--Areal distribution of benzene concentrations analyzed in 1989. 


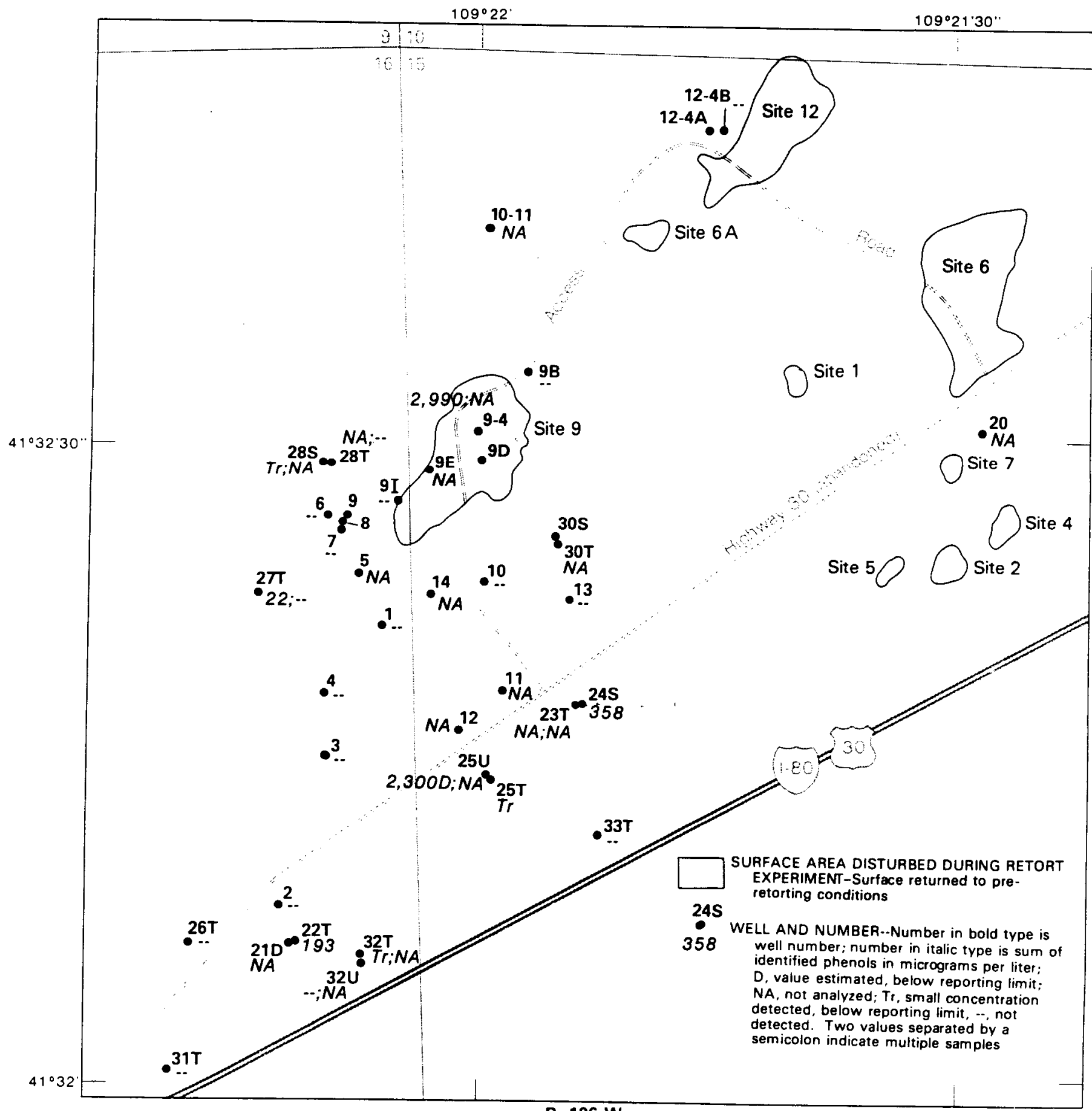

R. 106 W.

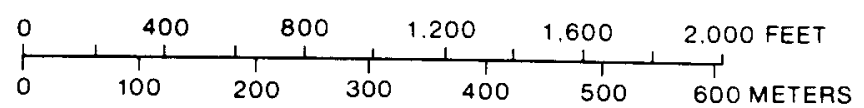

Figure 10.--Areal distribution of sum of identified phenols analyzed in 1989. 


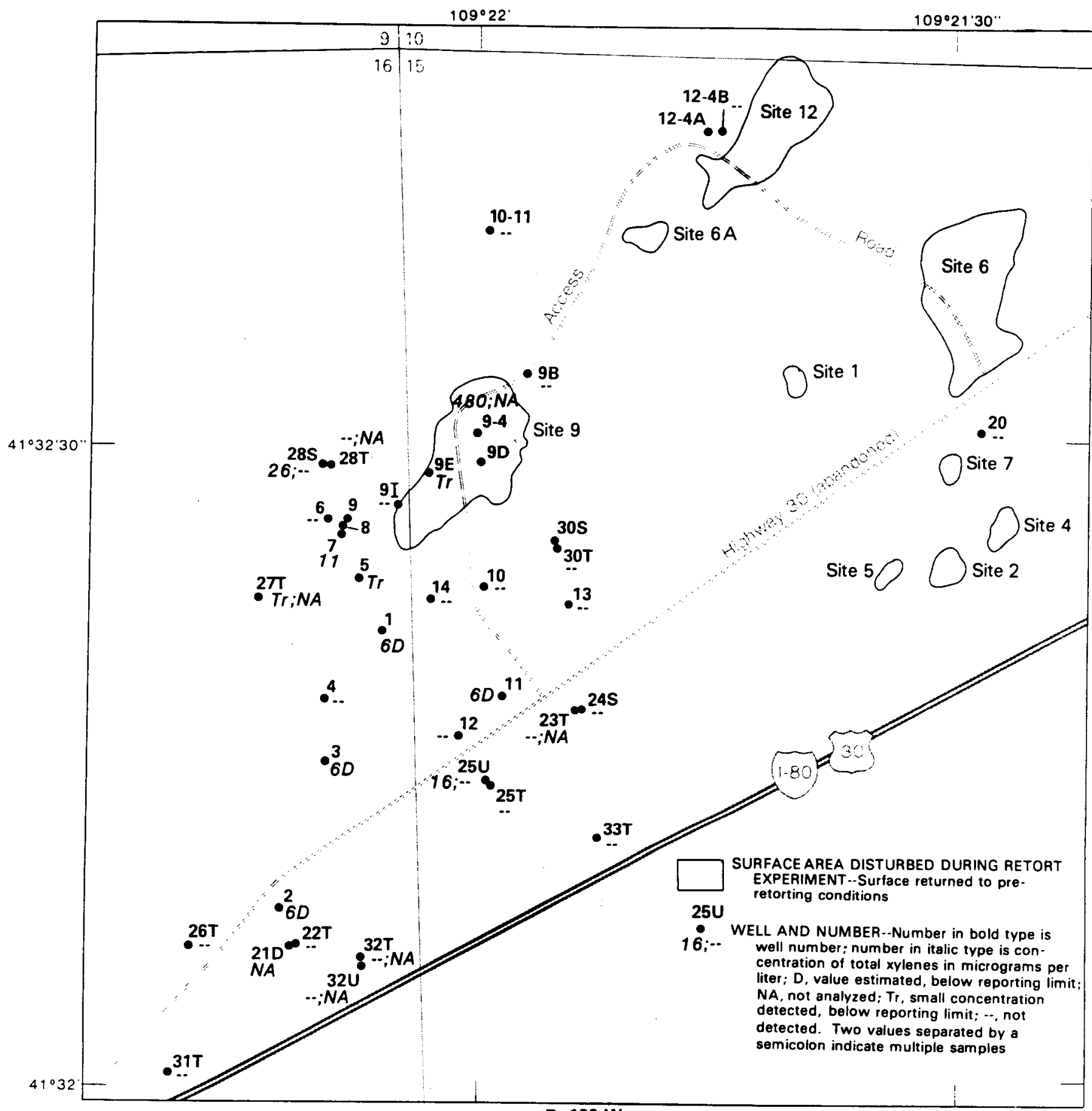

R. 106 W.

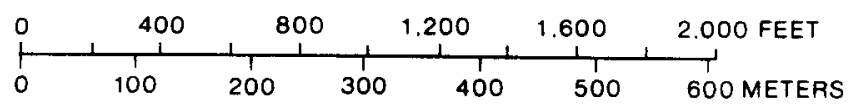

Figure 11.--Areal distribution of total xylenes analyzed in 1989 . 


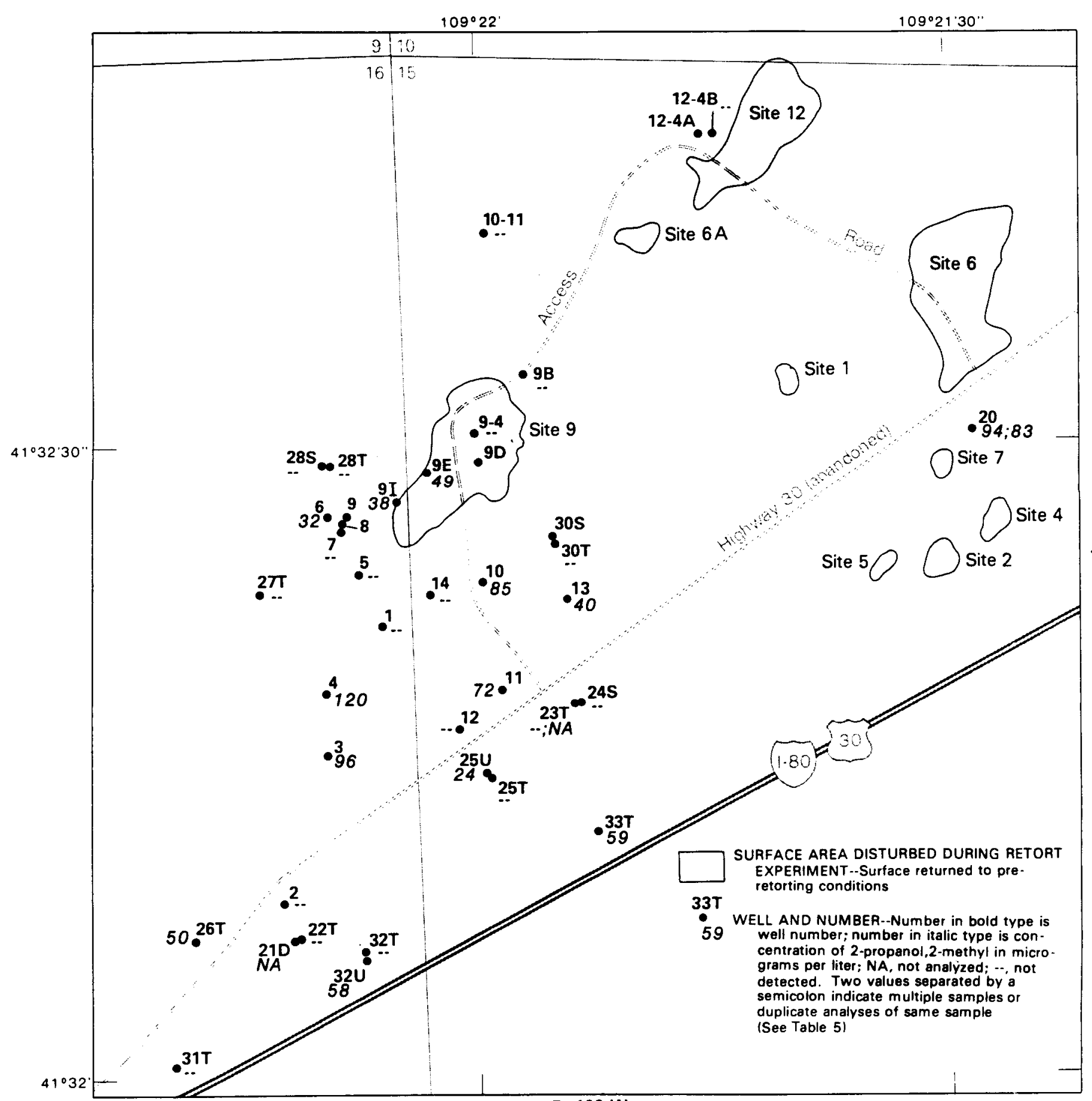

R. 106 W.

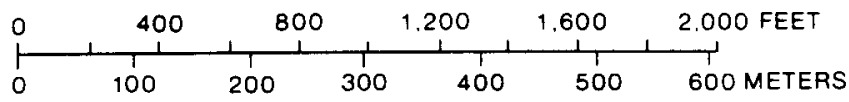

Figure 12.--Areal distribution of 2-propanol,2-methyl concentrations analyzed in 1989. 


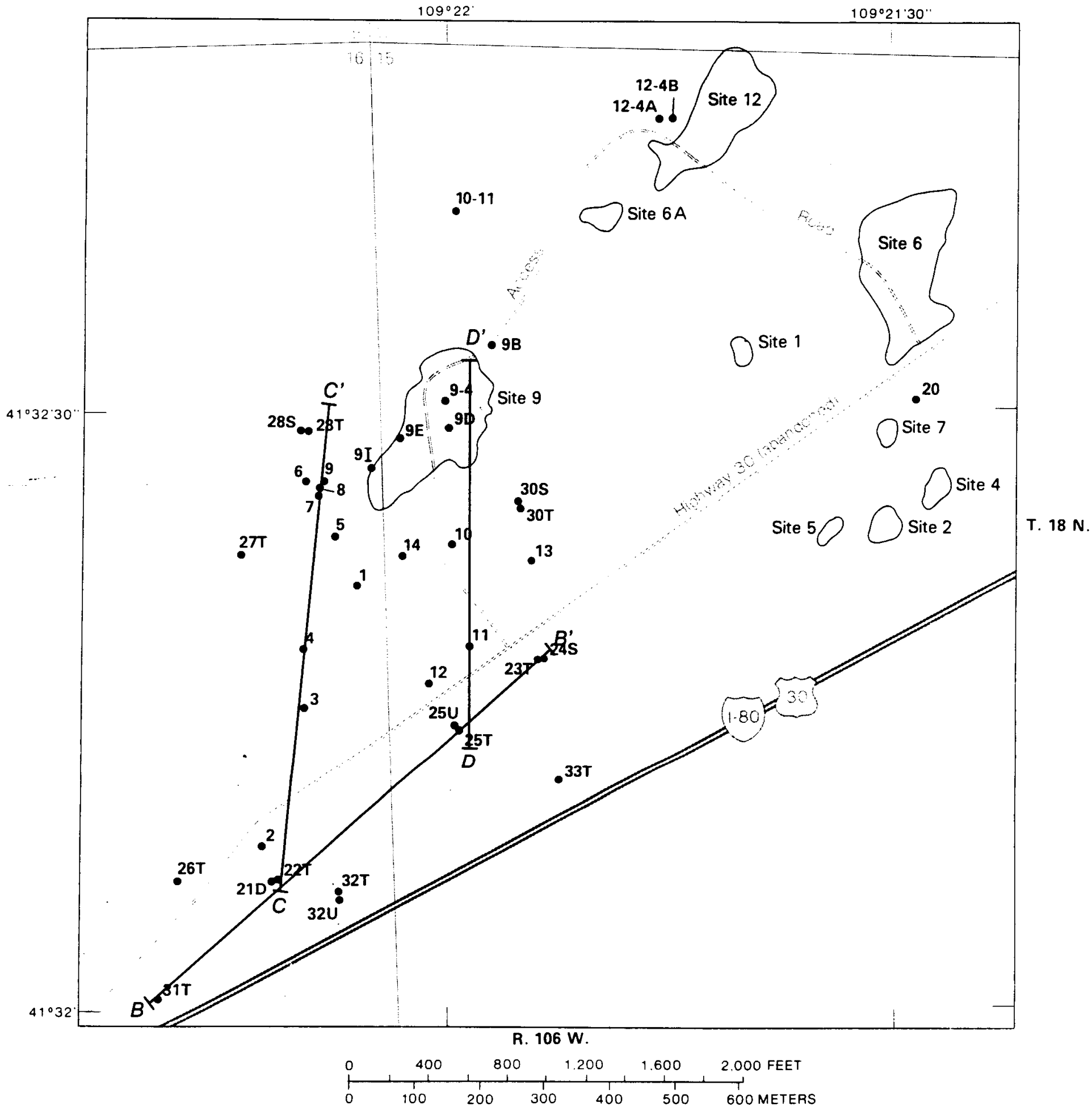

Figure 13.--Location of geologic sections. 


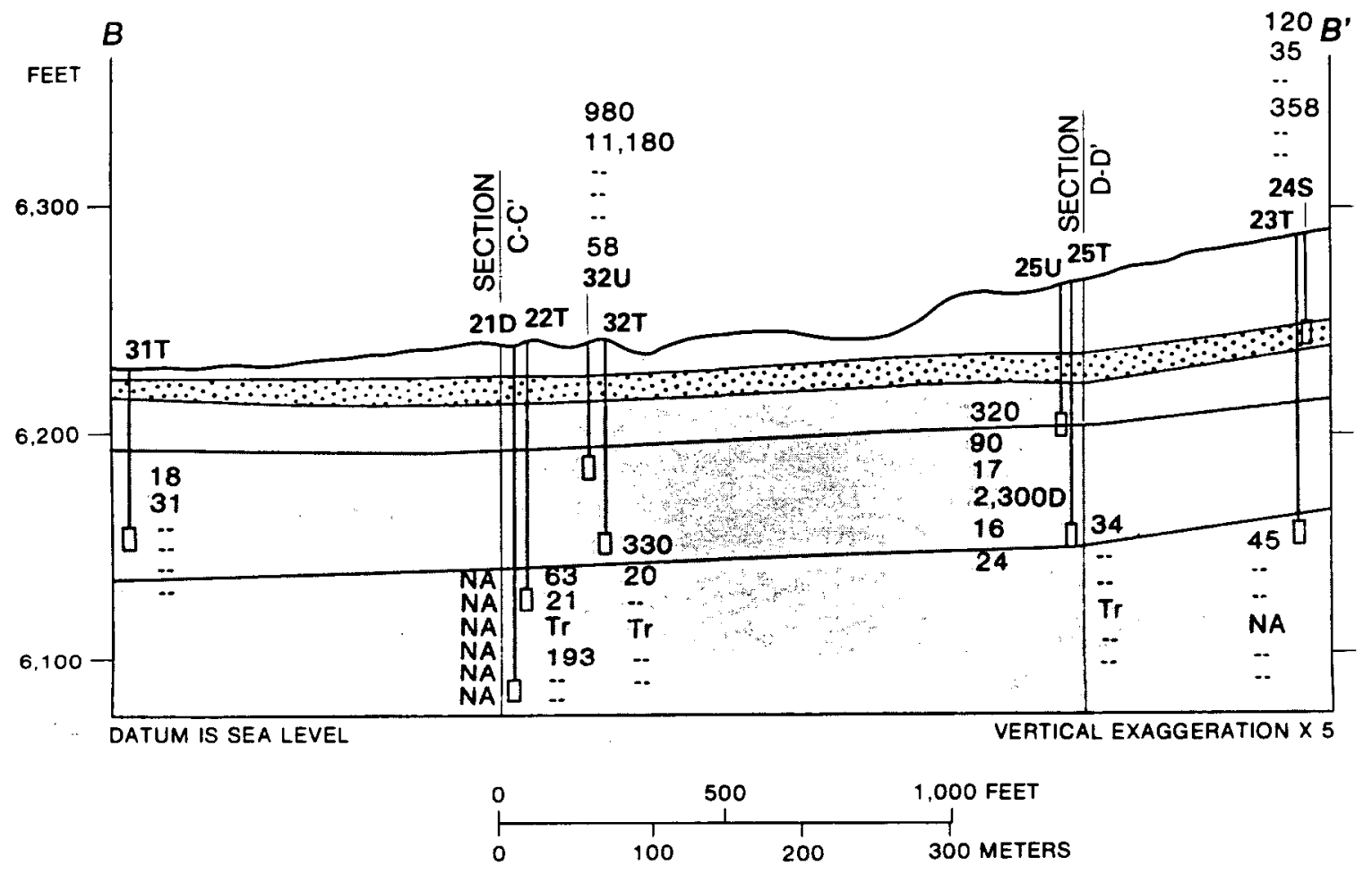

EXPLANATION

WILKINS PEAK CONFINING UNIT

UPPERMOST SANDSTONE IN TIPTON AQUIFER

TIPTON AQUIFER

PRODUCED ZONE IN TIPTON AQUIFER

CONCENTRATION OF SELECTED ORGANIC CONSTITUENTS, IN MICROGRAMS PER LITER ANALYZED IN 1989.-Top number is acetone; second number is sum of identified ketones (excluding acetone); third number is benzene; fourth number is sum of identified phenols; fifth number is total xylenes; sixth number is 2-propanol, 2 -methyl; $D$, value estimated below reporting limit; NA, not analyzed; Tr, small concentration detected below reporting limit; -., not detected

210

WELL AND NUMBER AND OPEN INTERVAL

Figure 14.--Vertical distribution of concentration of selected organic constituents at section B-B'. 
C

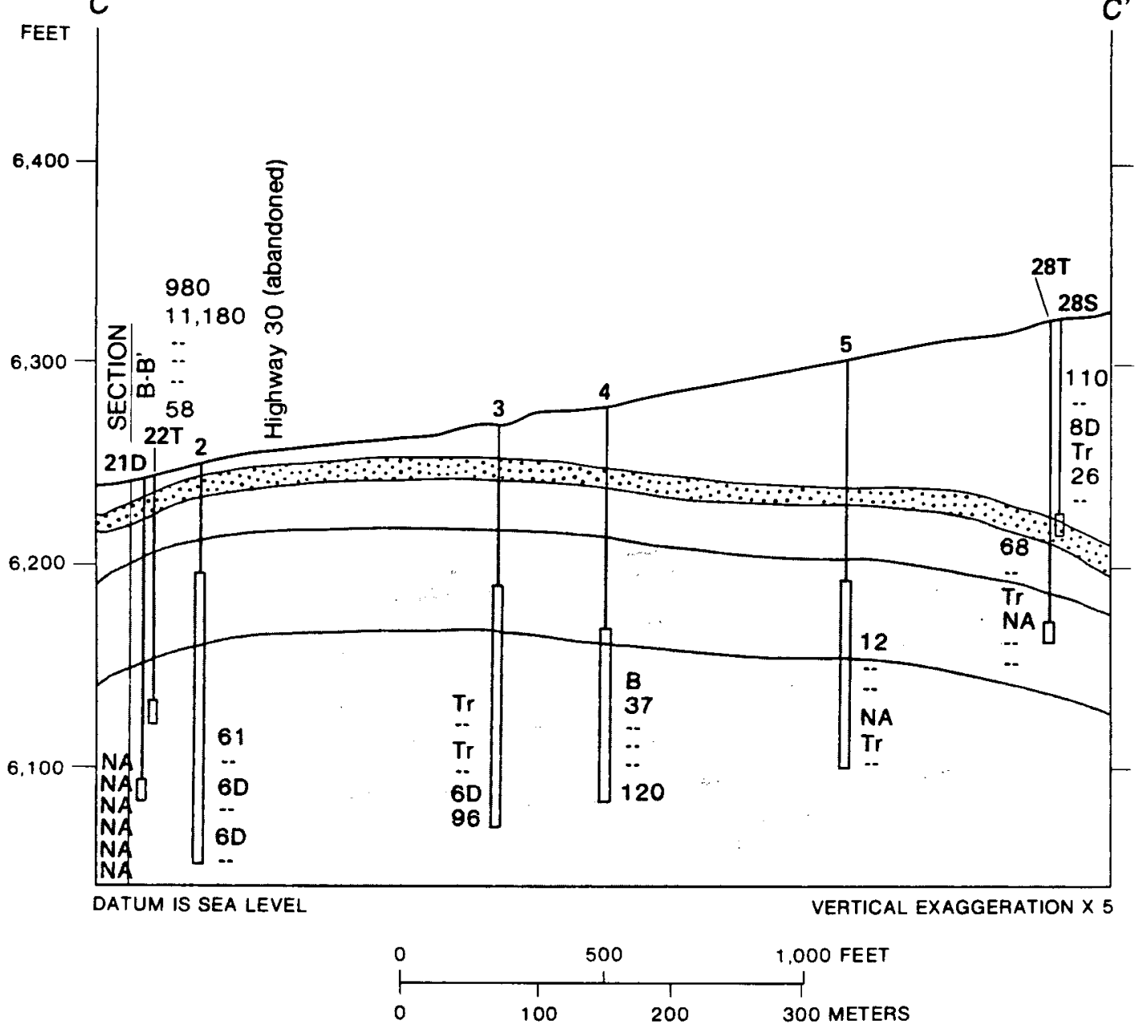

EXPLANATION

WILKINS PEAK CONFINING UNIT

$\because$ UPPERMOST SANDSTONE IN TIPTON AQUIFER

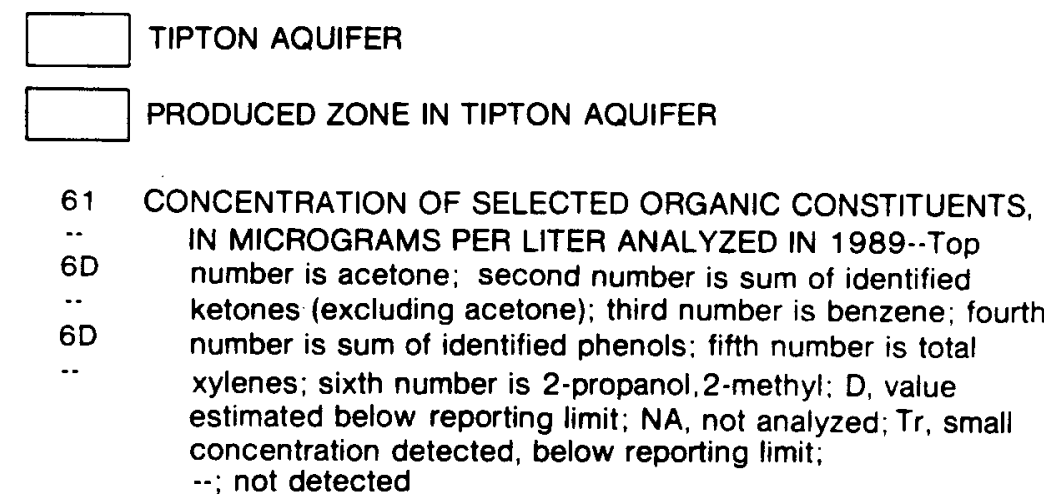

2

WELL AND NUMBER AND OPEN INTERVAL

1

Figure 15.--Vertical distribution of concentration of selected organic constituents at section C-C'. 


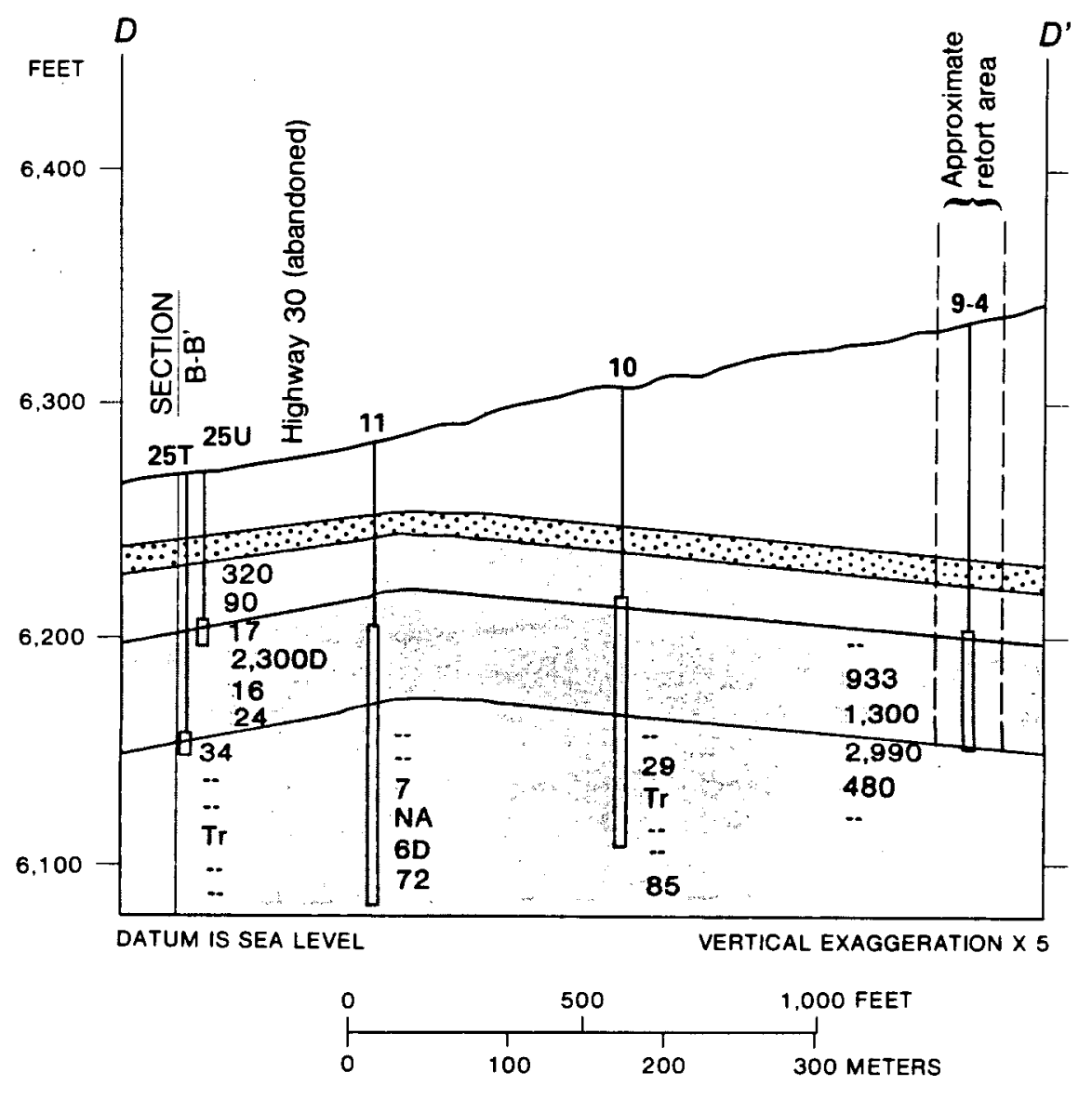

EXPLANATION

WILKINS PEAK CONFINING UNIT

UPPERMOST SANDSTONE IN TIPTON AQUIFER

TIPTON AQUIFER

PRODUCED ZONE IN TIPTON AQUIFER

34 CONCENTRATION OF SELECTED ORGANIC CONSTITUENTS,

$\because \quad$ IN MICROGRAMS PER LITER ANALYZED IN 1989-.-TOP

$\because \quad$ number is acetone; second number is sum of identified

Tr ketones (excluding acetone); third number is benzene; fourth

$\because \quad$ number is sum of identified phenols; fifth number is total xylenes: sixth number is 2-propanol, 2 -methyl; $D$, value estimated below reporting limit; NA, not analyzed; $T r$, small concentration detected, below reporting limit; $\cdots$; not detected

25T WELL AND NUMBER AND OPEN INTERVAL

Figure 16.--Vertical distribution of concentration of selected organic constituents at section D-D'. 
Movement of benzene, the heavier ketones, and several other nonpolar organic compounds such as azaarenes, which are detected only in or near the retort chamber, may be retarded relative to movement of polar compounds and ions, probably because the nonpolar compounds are more readily adsorbed onto organic material in the shale. This process would be expected to be important only where the water is moving slowly through bedding planes and small

fractures. Where water is moving rapidly through large fractures, there would not be time for sorption to occur (J.A. Leenheer, U.S. Geological Survey, oral commun., 1989). An alternative possibility is that these compounds could be degraded by microbiological activity before they have moved far from the retort chamber, but the high $\mathrm{pH}$ of water in the Tipton aquifer makes this mechanism less likely than adsorption. A third possibility is that some of the compounds formed new compounds that are stable and insoluble at high pH by interacting with inorganic constituents present in the water. Benzene, for example, was not detected in wells far from the retort chamber. Concentrations of benzene in the retort chamber (Figure 9, well 9-4) are greater than those elsewhere in the study area, by almost two orders of magnitude. The other organic contaminants mapped in Figures 7 through 12--sum of identified phenols, total xylenes, and 2-propanol,2-methyl--show similar variations; the polar compounds (phenols and 2-propanol,2-methyl) are more widely dispersed than nonpolar compounds ( $x y l$ lenes).

Vertical distribution of organic contaminants also provides information about the stratified nature of the flow system in the Tipton aquifer. There are substantial differences in water quality between the deeper and shallower wells of most paired wells. The differences imply that little, if any, vertical flow or mixing is taking place at those locations, despite the presence of vertical hydraulic-head gradients.

\section{Inorganic Constituents}

The dissolved inorganic constituents in the water are the result of the retort experiments and of the naturally occurring trona water described in the "Pre-Retorting Quality" section. Attributed to the retort experiment are the high ratios of calcium and potassium to sodium, compared to ratios in uncontaminated ground water at the site. Values of $\mathrm{pH}$ greater than about 11 and elevated concentrations of some nitrogen and sulfur species, arsenic, boron, cyanide, and fluoride also are attributed to the retort experiment (J.A. Leenheer, U.S. Geological Survey, oral commun., 1989). Large concentrations of other inorganic constituents are presumed to be of natural origin.

The results of laboratory analyses for inorganic constituents detected in water samples collected from wells in 1989 are listed in Table 8, as well as the results of onsite measurements of specific conductance and $\mathrm{pH}$. Results of trace-metal analysis are listed in Table 9. Most of the wells sampled for this analysis were drilled in 1989. As described previously, the open-hole construction in older wells results in the mixing of water from several

different depths, making interpretation difficult. Well 3 , along the main northeast to southwest path of the contaminant movement predicted by Glover (1988, p. 22), and well 12, just east of the main path, were included in the analysis to provide historical continuity despite their open-hole construction. In addition, well 12 was chosen because of its close proximity to wells $25 \mathrm{U}$ and $25 \mathrm{~T}$, which had unusually high values of several constituents. Because well 12 is of the long open-hole construction, data from it could also be used to evaluate the effects of vertical mixing and dilution. 
Areal distributions of ratios of selected cations, $\mathrm{pH}$, and concentration of molybdenum are shown in Figures 17 through 20. Other constituents attributed to the retort experiment are not mapped because data were insufficient, or too variable compared with pre-retorting conditions in the aquifer for meaningful analysis. Because these maps depict data from wells open to different intervals in the Tipton aquifer, they should be used with caution. Areal distributions of calcium-to-sodium and potassium-to-sodium ratios determined for water samples collected in 1981-83 and 1989 are shown in Figures 17 and 18. For ease of presentation, the calculated ratio has been multiplied by a factor of 10,000 . The baseline value of this ratio for water in the Tipton aquifer at site 9, calculated from mean pre-retorting water quality presented by Western Research Institute (1988, p. 21) is about 0.0025 for calcium to sodium and 0.0024 for potassium to sodium. (Use ratio of 25 for comparison with Figure 17 and ratio of 24 for comparison with Figure 18.) Figure 19 shows $\mathrm{pH}$ values measured in 1989. The $\mathrm{pH}$ of the water ranged from 8.5 to 13.2. The $\mathrm{pH}$ of approximately 8.5 to 11 can be attributed to the dissolved carbonate minerals of natural origin, such as nahcolite and trona. However, pH greater than 11 may be caused by slaking of lime created by the retort process (J.A. Leenheer, U.S. Geological Survey, oral commun., 1989). Molybdenum concentrations are shown in Figure 20. Minimum and maximum concentrations of molybdenum in the Tipton aquifer showed a decrease in concentration after retorting. Before retorting began, molybdenum concentrations at the site ranged from 37 to $5,800 \mu \mathrm{g} / \mathrm{L}$; in 1989 , concentrations ranged from 11 to $3,600 \mathrm{\mu g} / \mathrm{L}$. It is suggested that the decrease is because the higher $\mathrm{pH}$ after retorting caused the molybdenum present in the ground water to become less soluble, hence less mobile. The same data are displayed in cross section in Figures 21 through 23.

Thiocyanate has been identified in previous studies as a conservative tracer of contaminant movement. Laboratory personnel attempted to analyze all water samples for thiocyanate, but chemical interferences made the analysis inconclusive. Of 17 water samples from 15 wells for which thiocyanate analyses were attempted, no determination was made for 10 samples, and the other 7 had thiocyanate reported at less than $0.5 \mathrm{mg} / \mathrm{L}$. Other sulfur species also were difficult to analyze, or presented interference problems for the laboratory. The unexpectedly high $\mathrm{pH}$ of the water caused the ammonia nitrogen analyses to be unreliable. These constituents are reported by Eddy and others (1991). 
Table 8.--Major inorganic constituents detected in water samples collected from observation wells in 1989

[A11 constituents analyzed were in dissolved form; concentrations reported in milligrams per 11 ter uniess otherwise noted; $\mu$ S/cm, microsiemens per centimeter at 25 degrees Celsius; NA, not analyzed; <, less than indicated detection 1imit; >, greater than indicated reporting limit. Detection 1 imit is determined statistically using the U.S. Environmental Protection Agency's Contract Laboratory Program. All numbers in table are rounded to two significant figures except for pH]

\begin{tabular}{|c|c|c|c|c|c|c|c|c|c|c|c|c|c|c|c|c|}
\hline Well & $\begin{array}{c}\text { Date } \\
\text { analyzed }\end{array}$ & $\begin{array}{c}\text { Field } \\
\text { specific } \\
\text { conduct- } \\
\text { ance } \\
(\mu \mathrm{s} / \mathrm{cm} \\
\left.\text { at } 25^{\circ} \mathrm{C}\right)\end{array}$ & $\begin{array}{c}\text { Field } \\
\mathrm{pH}\end{array}$ & $\begin{array}{l}\text { Calcium } \\
\text { (Ca) }\end{array}$ & $\begin{array}{l}\text { Magne- } \\
\text { sium } \\
(\mathrm{Mg})\end{array}$ & $\begin{array}{l}\text { Sodium } \\
\text { (Na) }\end{array}$ & $\begin{array}{l}\text { Potas- } \\
\text { sium } \\
(K)\end{array}$ & $\begin{array}{c}\text { Alka- } \\
\text { linity, } \\
\text { total } \\
\text { as } \\
\mathrm{CaCO}_{3}\end{array}$ & $\begin{array}{l}\text { Sul- } \\
\text { fate, } \\
\text { as } \mathrm{SO}_{4}\end{array}$ & $\begin{array}{l}\text { Chlo- } \\
\text { ride } \\
\text { (Cl) }\end{array}$ & $\begin{array}{l}\text { Fluo- } \\
\text { ride } \\
\text { (F) }\end{array}$ & $\begin{array}{l}\text { Bro- } \\
\text { mide } \\
(\mathrm{Br})\end{array}$ & $\begin{array}{l}\text { Solids, } \\
\text { residue }\end{array}$ & $\begin{array}{l}\mathrm{Ni}- \\
\text { trite, } \\
\text { as } N\end{array}$ & $\begin{array}{l}\mathrm{Ni}- \\
\text { trate, } \\
\text { as } \mathrm{N}\end{array}$ & $\begin{array}{l}\text { Nitro- } \\
\text { gen, } \\
\text { ammonia, } \\
\text { as N }\end{array}$ \\
\hline 1 & $5-89$ & 45,000 & 9.8 & NA & NA & NA & NA & $N A$ & $N A$ & NA & $N A$ & NA & NA & NA & NA & NA \\
\hline 2 & $5-89$ & 48,000 & 9.8 & NA & NA & NA & NA & NA & NA & NA & NA & NA & NA & NA & NA & NA \\
\hline \multirow[t]{2}{*}{3} & $6-89$ & 20,000 & 8.7 & 15 & 19 & 4,400 & 6.4 & 1,800 & $<5$ & 5,600 & 3.2 & 18 & 12,000 & $<0.03$ & NA & 5.7 \\
\hline & $8-89$ & 20,000 & 9.0 & NA & NA & NA & NA & NA & NA & NA & NA & NA & $N A$ & NA & NA & NA \\
\hline \multirow[t]{2}{*}{4} & $5-89$ & 24,000 & 9.3 & $N A$ & NA & NA & NA & NA & NA & NA & NA & NA & NA & NA & NA & NA \\
\hline & $8-89$ & 30,000 & 9.5 & NA & NA & NA & NA & NA & NA & NA & NA & NA & NA & NA & NA & NA \\
\hline 5 & $8-89$ & 21,000 & 8.9 & NA & NA & NA & NA & NA & $N A$ & NA & NA & NA & NA & NA & NA & NA \\
\hline 6 & $5-89$ & 25,000 & 9.9 & NA & NA & NA & NA & NA & NA & NA & NA & NA & NA & NA & NA & NA \\
\hline 7 & $7-89$ & 2,300 & 9.9 & NA & NA & NA & NA & 930 & 25 & 210 & 5.1 & $<5$ & 1,400 & $<.03$ & $<0.03$ & 1.6 \\
\hline \multirow[t]{2}{*}{10} & $5-89$ & 30,000 & 9.8 & NA & NA & NA & NA & NA & NA & NA & NA & NA & NA & NA & NA & NA \\
\hline & $8-89$ & 30,000 & 9.9 & NA & NA & NA & NA & NA & NA & NA & NA & NA & NA & NA & NA & NA \\
\hline \multirow[t]{2}{*}{11} & $6-89$ & 17,000 & 8.8 & NA & NA & NA & NA & NA & NA & NA & $N A$ & NA & NA & NA & NA & NA \\
\hline & $8-89$ & 14,000 & 8.9 & NA & NA & $N A$ & NA & NA & NA & NA & $N A$ & NA & $N A$ & NA & NA & NA \\
\hline 12 & $3-89$ & 17,000 & 8.5 & 14 & 14 & 4,000 & 7.2 & 2,200 & $<5$ & 3,900 & 6.0 & 9.3 & 9,900 & $<.03$ & $<.90$ & 5.4 \\
\hline \multirow[t]{2}{*}{13} & $5-89$ & 13,000 & 9.2 & NA & NA & NA & NA & NA & NA & NA & NA & NA & NA & NA & NA & NA \\
\hline & $8-89$ & 14,000 & 9.3 & $N A$ & NA & NA & NA & NA & NA & NA & NA & NA & NA & NA & NA & NA \\
\hline \multirow[t]{2}{*}{14} & $6-89$ & 1,400 & 9.5 & NA & NA & NA & NA & NA & NA & NA & NA & NA & NA & NA & NA & NA \\
\hline & $8-89$ & 1,200 & 9.6 & NA & NA & NA & NA & NA & NA & NA & NA & NA & NA & NA & NA & $N A$ \\
\hline 20 & $6-89$ & 13,000 & 9.4 & NA & NA & NA & NA & NA & NA & NA & NA & NA & NA & NA & NA & $N A$ \\
\hline 210 & $3-89$ & NA & NA & 340 & $<.01$ & 2,200 & 560 & 6,400 & $<5$ & 84 & .3 & $<5$ & 5,900 & .08 & .29 & 4 \\
\hline \multirow[t]{2}{*}{$22 \mathrm{~T}$} & $6-89$ & 24,000 & 13.2 & 240 & $<.05$ & 2,100 & 600 & 5,900 & 8.5 & 110 & .4 & $<5$ & 6,000 & .05 & .25 & 5.1 \\
\hline & $8-89$ & 4,800 & 13.2 & $N A$ & $N A$ & $N A$ & NA & NA & NA & NA & NA & NA & NA & NA & NA & $N A$ \\
\hline
\end{tabular}


Table 8.--Major inorganic constituents detected in water samples collected from observation wells in 1989--Continued

\begin{tabular}{|c|c|c|c|c|c|c|c|c|c|c|c|c|c|c|c|c|}
\hline Well & $\begin{array}{c}\text { Date } \\
\text { analyzed }\end{array}$ & $\begin{array}{c}\text { Field } \\
\text { specific } \\
\text { conduct- } \\
\text { ance } \\
(\mu \mathrm{S} / \mathrm{cm} \\
\left.\text { at } 25^{\circ} \mathrm{C}\right)\end{array}$ & $\begin{array}{c}\text { Field } \\
\mathrm{pH}\end{array}$ & $\begin{array}{l}\text { Calcium } \\
\text { (Ca) }\end{array}$ & $\begin{array}{l}\text { Magne- } \\
\text { sium } \\
(\mathrm{Mg})\end{array}$ & $\begin{array}{l}\text { Sodium } \\
\text { (Na) }\end{array}$ & $\begin{array}{c}\text { Potas- } \\
\text { sium } \\
\text { (k) }\end{array}$ & $\begin{array}{l}\text { Alka- } \\
\text { linity, } \\
\text { total } \\
\text { as } \\
\mathrm{CaCO}_{3}\end{array}$ & $\begin{array}{l}\text { Sul- } \\
\text { fate, } \\
\text { as } \mathrm{SO}_{4}\end{array}$ & $\begin{array}{l}\text { Chlo- } \\
\text { ride } \\
(\mathrm{Cl})\end{array}$ & $\begin{array}{l}\text { Fluo- } \\
\text { ride } \\
\text { (F) }\end{array}$ & $\begin{array}{l}\text { Bro- } \\
\text { mide } \\
(\mathrm{Br})\end{array}$ & $\begin{array}{l}\text { Solids, } \\
\text { residue }\end{array}$ & $\begin{array}{l}\mathrm{Ni}- \\
\text { trite, } \\
\text { as N }\end{array}$ & $\begin{array}{l}\mathrm{Ni}- \\
\text { trate, } \\
\text { as } \mathrm{N}\end{array}$ & $\begin{array}{l}\text { Nitro- } \\
\text { gen, } \\
\text { ammonia, } \\
\text { as } N\end{array}$ \\
\hline \multirow[t]{3}{*}{$23 T$} & $3-89$ & NA & NA & 370 & .01 & 2,300 & 380 & 5,600 & 270 & 480 & .3 & $<5$ & 6,600 & NA & NA & NA \\
\hline & $6-89$ & NA & $N A$ & 400 & $<.05$ & 4,000 & 160 & 4,800 & 6.5 & 4,100 & .3 & 10 & 12,000 & $<.03$ & .18 & 14 \\
\hline & $8-89$ & 28,000 & 13.0 & NA & NA & NA & NA & NA & NA & NA & NA & NA & NA & NA & NA & NA \\
\hline 245 & $3-89$ & 24,000 & 13.2 & 400 & $<.01$ & 840 & 430 & 3,900 & 1,200 & 260 & .2 & $<5$ & 5,400 & NA & NA & NA \\
\hline \multirow[t]{2}{*}{$25 U$} & $6-89$ & 48,000 & 9.8 & 16 & 5.5 & 18,000 & 40 & 37,000 & 25 & 2,200 & 120 & 16 & 57,000 & $<.03$ & NA & 27 \\
\hline & $8-89$ & 40,000 & 10.1 & NA & NA & NA & $N A$ & NA & NA & NA & NA & NA & NA & NA & NA & NA \\
\hline $25 \mathrm{~T}$ & $6-89$ & 16,000 & 12.8 & 130 & $<.05$ & 2,000 & 180 & 3,000 & 2,000 & 610 & 5.1 & 8.9 & 8,000 & $<.03$ & 2.2 & 3.9 \\
\hline \multirow[t]{2}{*}{$26 \mathrm{~T}$} & $6-89$ & 13,000 & 11.9 & 3.6 & .80 & 2,600 & 140 & 830 & 500 & 3,500 & 1.6 & 15 & 7,700 & $<.03$ & .04 & 6.1 \\
\hline & $8-89$ & 6,500 & 8.5 & NA & NA & NA & NA & NA & NA & NA & NA & NA & NA & NA & NA & $N A$ \\
\hline \multirow[t]{2}{*}{$27 T$} & $3-89$ & NA & NA & 14 & $<.01$ & 1,400 & 22 & 1,900 & 690 & 280 & 2.4 & $<5$ & 3,200 & $<.03$ & .58 & 4.7 \\
\hline & $6-89$ & 13,000 & 12.9 & 110 & $<.05$ & 1,200 & 62 & 2,400 & 520 & 260 & 2.0 & $<5$ & 3,600 & .03 & .42 & 4.2 \\
\hline \multirow[t]{3}{*}{285} & $5-89$ & NA & 12.1 & NA & $N A$ & NA & NA & NA & NA & NA & NA & NA & NA & NA & NA & NA \\
\hline & $6-89$ & 3,900 & 11.3 & NA & NA & NA & NA & NA & NA & NA & NA & NA & NA & NA & $N A$ & NA \\
\hline & $8-89$ & 6,000 & 10.2 & NA & NA & NA & NA & $N A$ & NA & NA & NA & NA & NA & NA & NA & NA \\
\hline \multirow[t]{3}{*}{$28 \mathrm{~T}$} & $3-89$ & 9,300 & 12.1 & 9.2 & .22 & 2,200 & 82 & 3,100 & 780 & 450 & 9.8 & $<5$ & 6,200 & .14 & .13 & 4.4 \\
\hline & $5-89$ & 5,800 & NA & NA & NA & NA & NA & NA & NA & NA & NA & NA & NA & NA & NA & NA \\
\hline & $8-89$ & 10,000 & 12.1 & NA & NA & NA & NA & NA & NA & NA & NA & NA & NA & NA & NA & NA \\
\hline \multirow[t]{3}{*}{$30 T$} & $3-89$ & NA & NA & 360 & $<.01$ & 780 & 190 & 2,200 & 470 & 260 & .7 & $<5$ & 3,100 & .04 & 1.2 & 2 \\
\hline & $6-89$ & 18,000 & 12.9 & NA & NA & NA & NA & NA & NA & $N A$ & NA & NA & NA & NA & NA & NA \\
\hline & $8-89$ & 28,000 & 12.9 & NA & NA & NA & NA & NA & NA & NA & NA & NA & NA & $N A$ & NA & NA \\
\hline \multirow[t]{2}{*}{$31 \mathrm{~T}$} & $6-89$ & 8,600 & 10.2 & NA & NA & NA & NA & 1,700 & 280 & 1,600 & 5.6 & 7.6 & 5,200 & NA & NA & NA \\
\hline & $8-89$ & 11,000 & 9.5 & NA & NA & NA & NA & 1,700 & 280 & 1,600 & 5.6 & 7.6 & 5,200 & NA & NA & NA \\
\hline \multirow[t]{2}{*}{$32 U$} & $6-89$ & 35,000 & 9.7 & 4.9 & 4.1 & 13,000 & 36 & 22,000 & 34 & 3,400 & 94 & 25 & 41,000 & .32 & $>.7$ & 22 \\
\hline & $8-89$ & 38,000 & 10.1 & $N A$ & NA & NA & NA & NA & NA & NA & NA & NA & NA & $N A$ & NA & NA \\
\hline \multirow[t]{2}{*}{$32 T$} & $6-89$ & 17,000 & 8.8 & 22 & 22 & 3,500 & 21 & 1,100 & 46 & 4,700 & 1.5 & 16 & 10,000 & $<.03$ & 2.3 & 4.8 \\
\hline & $8-89$ & 20,000 & 8.1 & NA & NA & NA & NA & NA & NA & NA & NA & NA & NA & $N A$ & $N A$ & NA \\
\hline \multirow[t]{2}{*}{$33 T$} & $6-89$ & 15,000 & 8.9 & 16 & 17 & 3,500 & 20 & 1,300 & 21 & 4,800 & 1.2 & 16 & 9,900 & $<.03$ & .05 & 4.4 \\
\hline & $8-89$ & 16,000 & 8.3 & NA & NA & NA & NA & NA & NA & NA & NA & NA & NA & NA & NA & NA \\
\hline
\end{tabular}


Table 9.--Trace metals detected in water samples collected from observation wells in 1989

[All metals were in dissolved form; concentrations in micrograms per liter; <, less than indicated detection limit. Detection

limit is determined statistically using the U.S. Environmental Protection Agency's Contract Laboratory Program. All numbers in table are rounded to two significant figures]

\begin{tabular}{|c|c|c|c|c|c|c|c|c|c|c|c|c|c|c|c|c|c|c|}
\hline Well & $\begin{array}{c}\text { Date } \\
\text { analyzed }\end{array}$ & $\begin{array}{l}\text { Alumi- } \\
\text { num }\end{array}$ & $\begin{array}{l}\text { Arse- } \\
\text { nic }\end{array}$ & Barium & $\begin{array}{l}\text { Beryl- } \\
\text { lium } \\
\end{array}$ & $\begin{array}{l}\text { Cad- } \\
\text { mium }\end{array}$ & $\begin{array}{l}\text { Chro- } \\
\text { mium }\end{array}$ & Cobalt & $\begin{array}{l}\text { Cop- } \\
\text { per }\end{array}$ & Iron & Lead & $\begin{array}{c}\text { Manga- } \\
\text { nese }\end{array}$ & $\begin{array}{l}\text { Mer- } \\
\text { cury }\end{array}$ & $\begin{array}{l}\text { Molyb- } \\
\text { denum }\end{array}$ & Nickel & $\begin{array}{l}\text { Sele- } \\
\text { nium }\end{array}$ & Silver & zinc \\
\hline 3 & $6-89$ & 140 & $<5$ & 1,600 & $<2$ & $<10$ & $<8$ & $<7$ & $<6$ & 510 & $<10$ & 33 & $<10$ & 11 & $<20$ & 18 & $<7$ & 83 \\
\hline 12 & $3-89$ & 180 & 9 & 1,300 & $<2$ & $<10$ & $<8$ & $<7$ & 16 & 140 & $<50$ & 50 & $<.2$ & 94 & $<20$ & $<5$ & $<7$ & 26 \\
\hline 210 & $3-89$ & 160 & $<5$ & 3,000 & $<2$ & $<10$ & $<8$ & $<7$ & 37 & 160 & $<50$ & $<3$ & $<.2$ & 280 & $<20$ & $<5$ & $<7$ & 22 \\
\hline $22 \mathrm{~T}$ & $6-89$ & 350 & $<5$ & 2,500 & $<2$ & $<10$ & 13 & $<7$ & 24 & 170 & $<10$ & $<3$ & $<10$ & 370 & $<20$ & $<5$ & $<7$ & 41 \\
\hline \multirow[t]{2}{*}{$23 \mathrm{~T}$} & $3-89$ & 75 & 75 & 900 & $<2$ & $<10$ & 95 & $<7$ & 29 & 120 & $<50$ & $<3$ & $<.2$ & 1,200 & $<20$ & 6 & $<7$ & 17 \\
\hline & $6-89$ & 120 & $<5$ & 5,400 & $<2$ & $<10$ & $<8$ & $<7$ & 23 & 75 & 28 & $<3$ & $<10$ & 720 & $<20$ & 16 & $<7$ & 220 \\
\hline $24 S$ & 3-89 & $<45$ & $<5$ & 360 & $<2$ & $<10$ & 600 & $<7$ & 37 & 44 & 130 & $<3$ & $<.2$ & 3,600 & $<20$ & $<5$ & $<7$ & 15 \\
\hline $25 U$ & $6-89$ & 250 & 10 & 280 & $<2$ & $<10$ & 27 & $<7$ & 11 & 770 & $<10$ & 37 & $<2$ & 74 & $<20$ & 17 & $<7$ & 220 \\
\hline $25 T$ & $6-89$ & 190 & $<5$ & 170 & $<2$ & $<10$ & 36 & $<7$ & 56 & 190 & 18 & $<3$ & $<10$ & 1,800 & $<20$ & 7 & $<7$ & 20 \\
\hline $26 \mathrm{~T}$ & $6-89$ & 680 & 16 & 170 & $<2$ & $<10$ & $<8$ & $<7$ & 12 & 1,600 & $<10$ & $<3$ & $<10$ & 1,500 & $<20$ & 15 & $<7$ & 45 \\
\hline \multirow[t]{2}{*}{$27 \mathrm{~T}$} & $3-89$ & 130 & 25 & 21 & $<2$ & $<10$ & $<8$ & $<7$ & 13 & 51 & $<50$ & $<3$ & .2 & 300 & $<20$ & $<5$ & $<7$ & 36 \\
\hline & $6-89$ & 260 & $<5$ & 350 & $<2$ & $<10$ & $<8$ & $<7$ & $<6$ & 180 & $<10$ & $<3$ & $<10$ & 550 & $<20$ & $<5$ & $<7$ & 59 \\
\hline $28 \mathrm{~T}$ & 3-89 & 490 & 25 & 15 & $<2$ & $<10$ & 67 & 13 & 21 & 730 & $<50$ & 4 & $<.2$ & 940 & $<20$ & $<5$ & $<7$ & 31 \\
\hline $30 T$ & $3-89$ & 89 & $<5$ & 320 & $<2$ & $<10$ & 200 & $<7$ & 200 & 280 & $<50$ & $<3$ & $<.2$ & 1,600 & $<20$ & $<5$ & $<7$ & 610 \\
\hline $32 \mathrm{U}$ & $6-89$ & 380 & 10 & 320 & $<2$ & $<10$ & 9 & $<7$ & $<6$ & 600 & $<10$ & 4 & $<2$ & 110 & $<20$ & 15 & $<7$ & 110 \\
\hline $32 \mathrm{~T}$ & $6-89$ & 180 & 12 & 98 & $<2$ & $<10$ & $<8$ & $<7$ & $<6$ & 84 & $<10$ & $<3$ & $<10$ & 81 & $<20$ & 12 & 10 & 26 \\
\hline 33T & $6-89$ & 61 & 13 & 1,800 & $<2$ & $<10$ & 67 & 13 & $<6$ & 63 & $<10$ & 4 & $<10$ & 88 & $<20$ & 9 & $<7$ & 45 \\
\hline
\end{tabular}




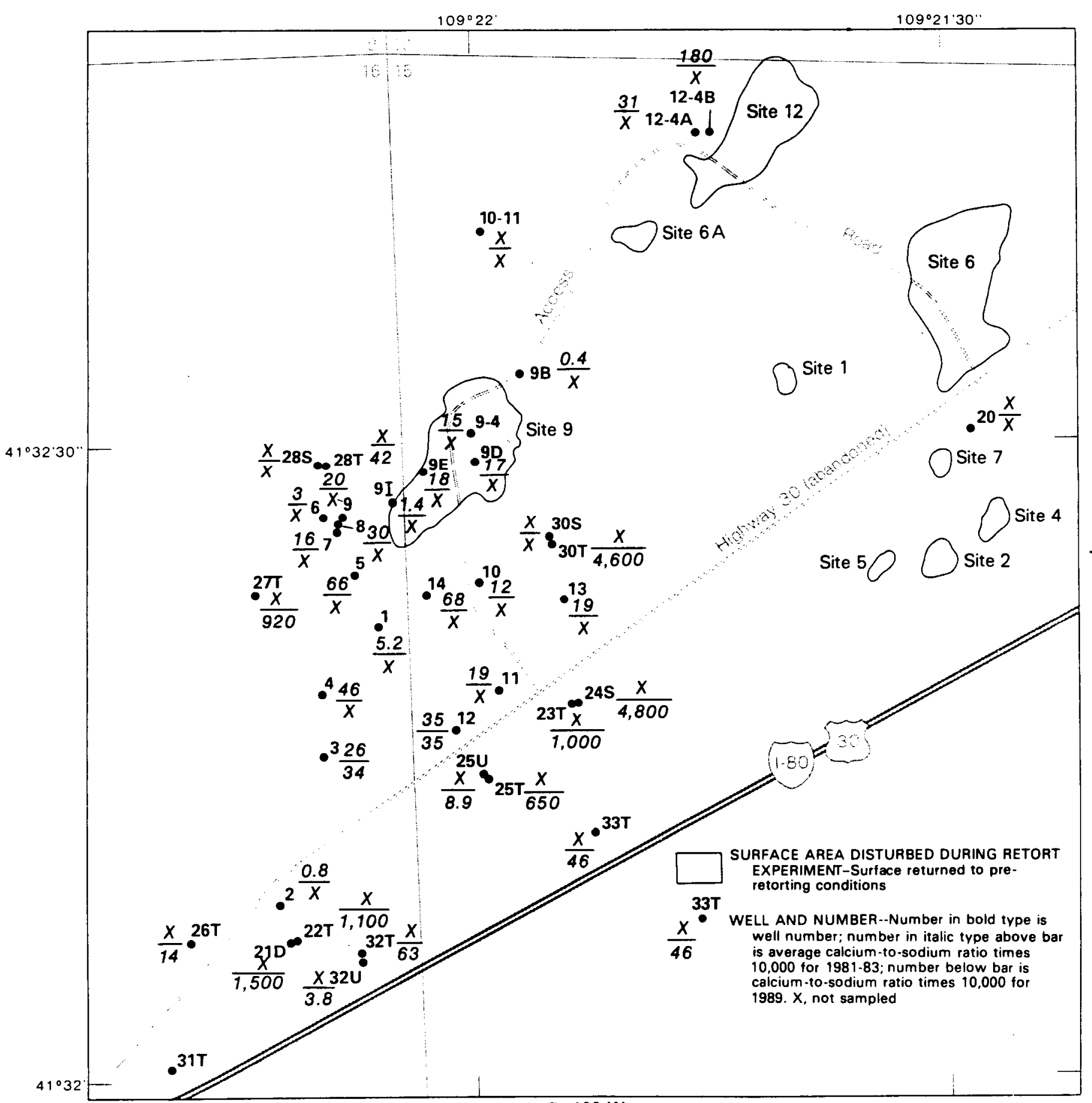

R. $106 \mathrm{~W}$.

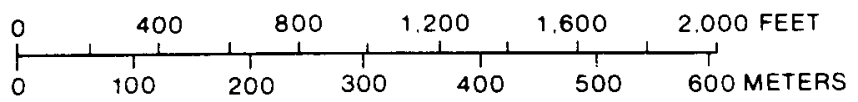

Figure 17.--Areal distribution of calcium-to-sodium ratio. 


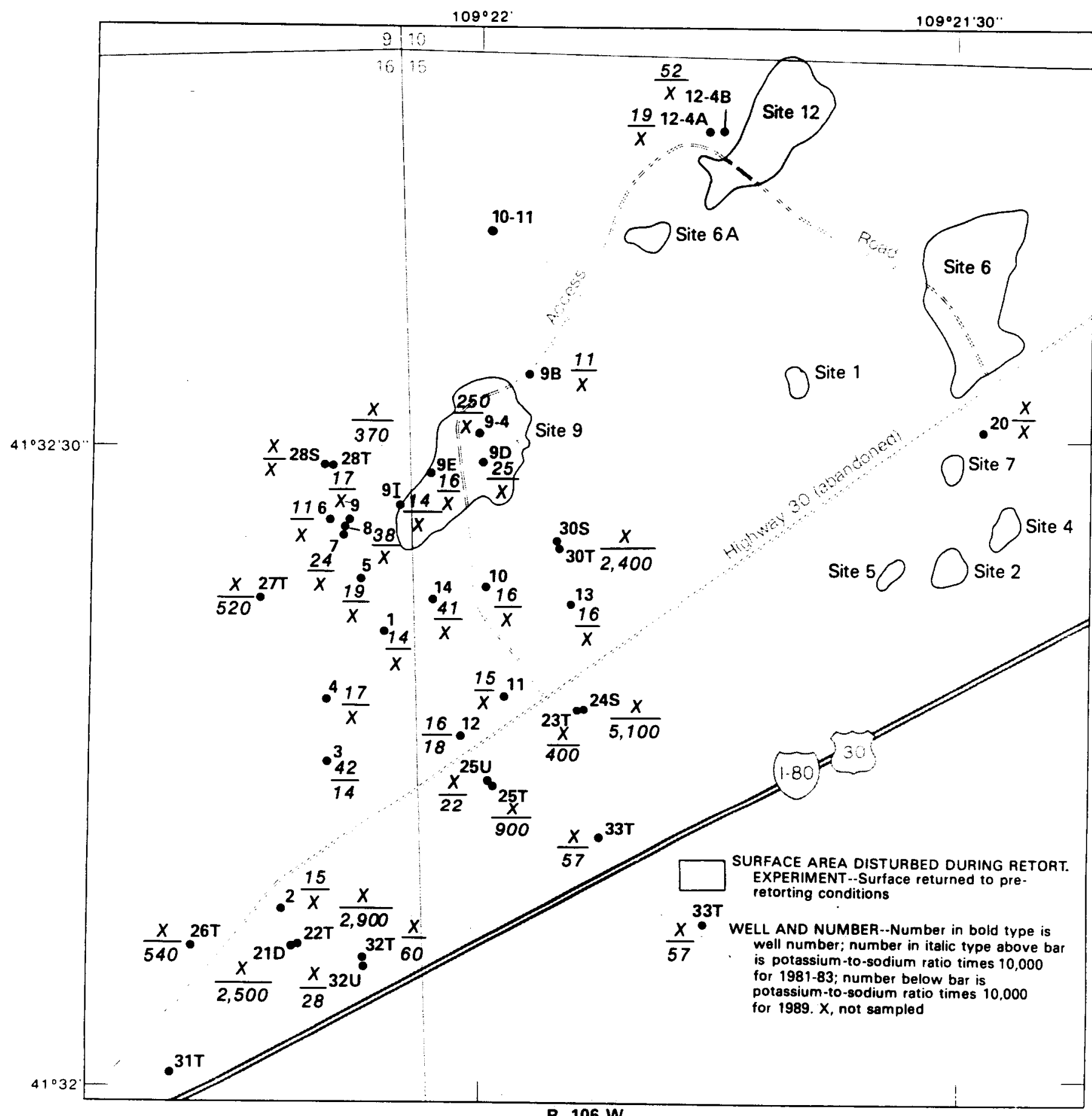

$109^{\circ} 2130$ 


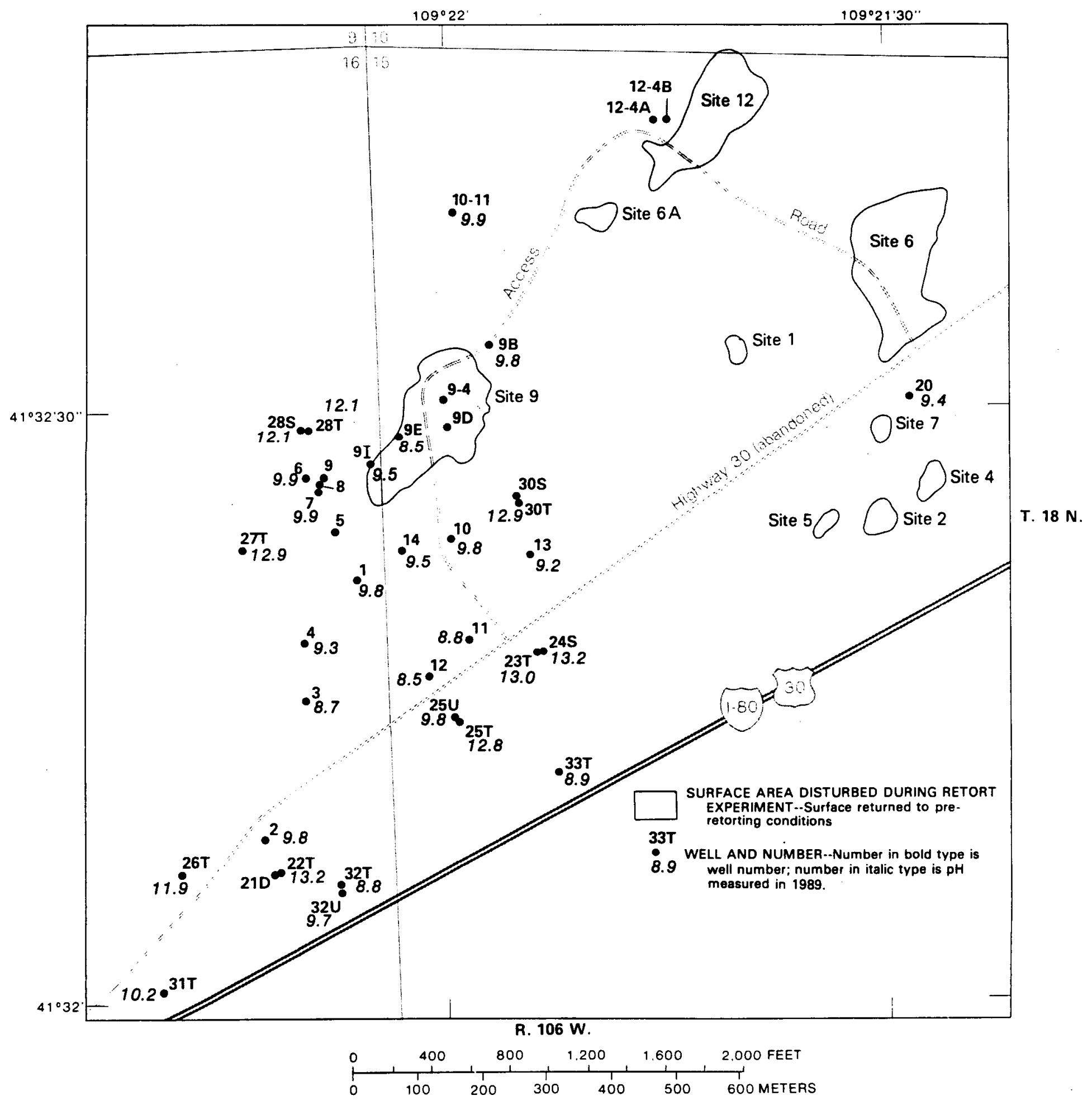

Figure 19.--Areal distribution of $\mathrm{pH}$. 


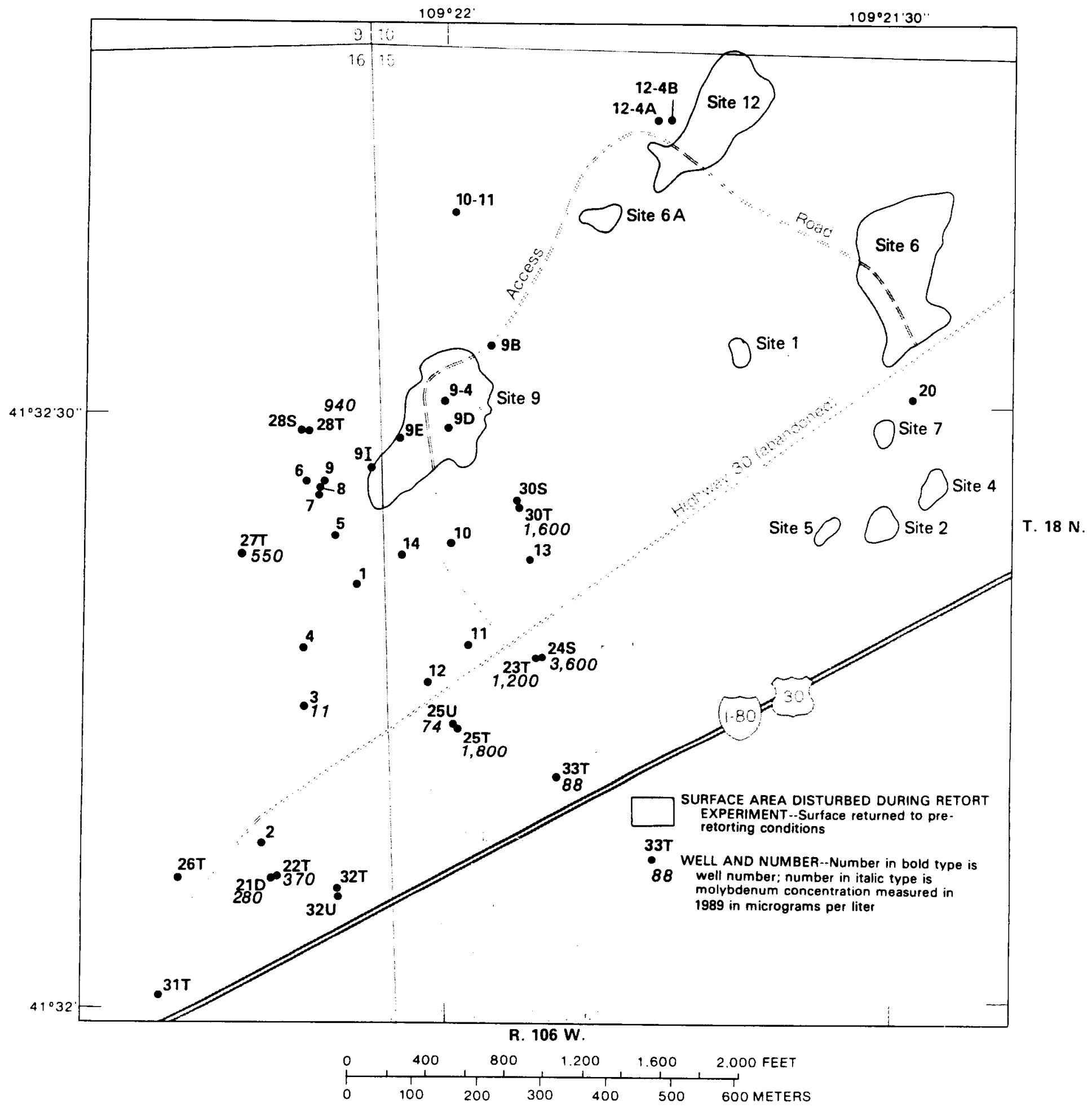

Figure 20.--Areal distribution of concentration of molybdenum. 


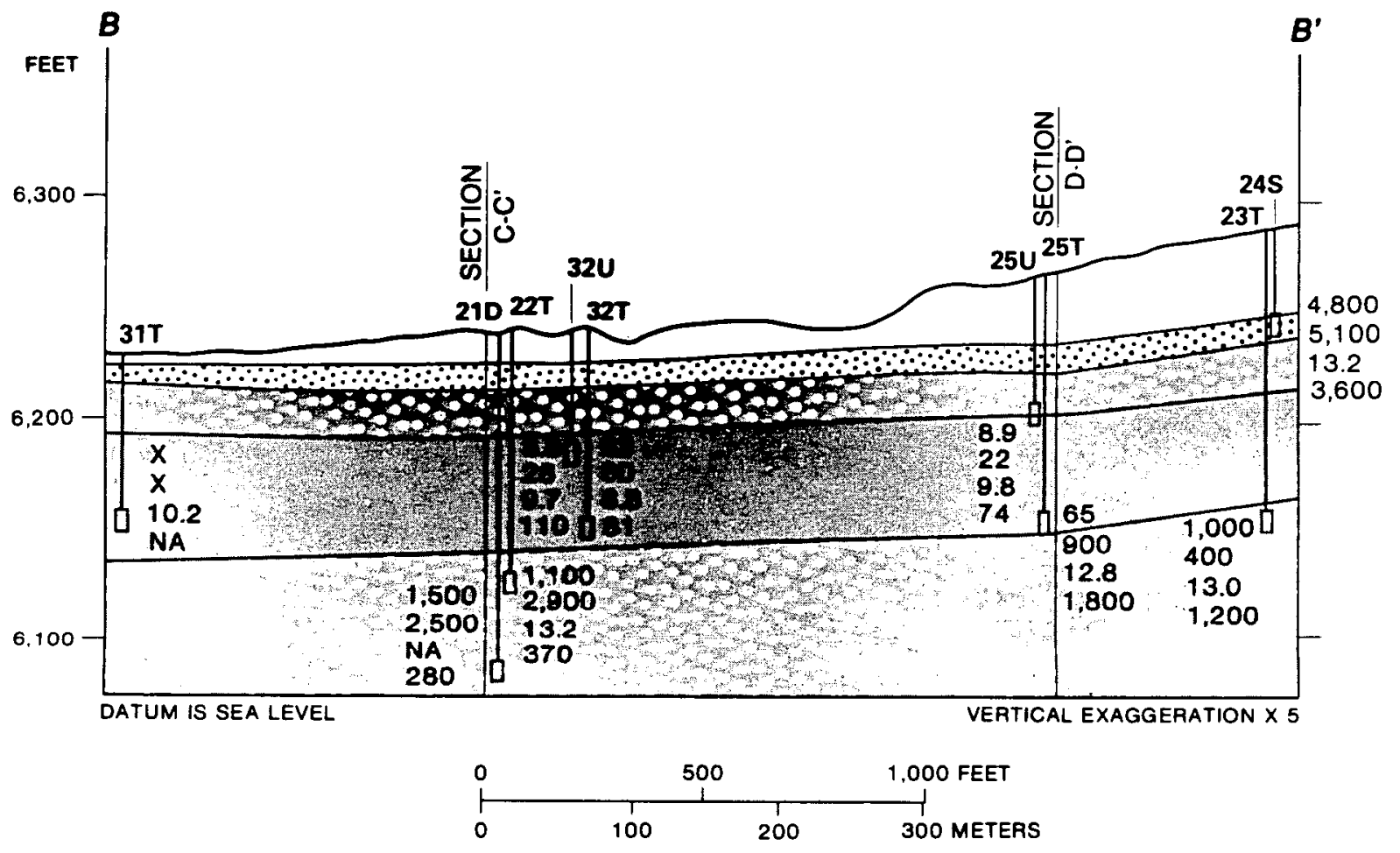

EXPLANATION

WILKINS PEAK CONFINING UNIT

$\because \because$ UPPERMOST SANDSTONE IN TIPTON AQUIFER

TIPTON AQUIFER

PRODUCED ZONE IN TIPTON AQUIFER

1,500 RATIOS OF SELECTED CATIONS, PH, AND CONCENTRATION

2,500 OF MOLYBDENUM IN MICROGRAMS PER LITER ANALYZED

NA IN 1989--Top number is calcium-to-sodium ratio times 10,000 ;

280 second number is potassium-to-sodium ratio times 10,000 ;

third number is $\mathrm{pH}$; fourth number is molybdenum concentration;

$N A$, not analyzed; $X$, not sampled

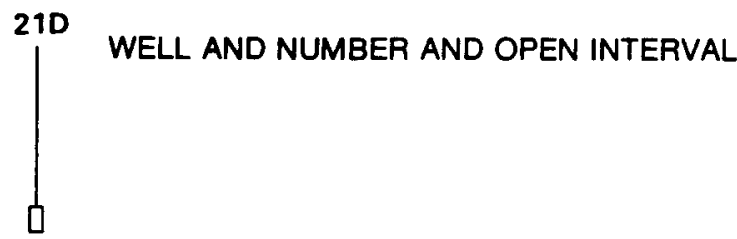

Figure 21.--Vertical distribution of ratios of selected cations, $\mathrm{pH}$, and concentration of molybdenum at section B-B'. 


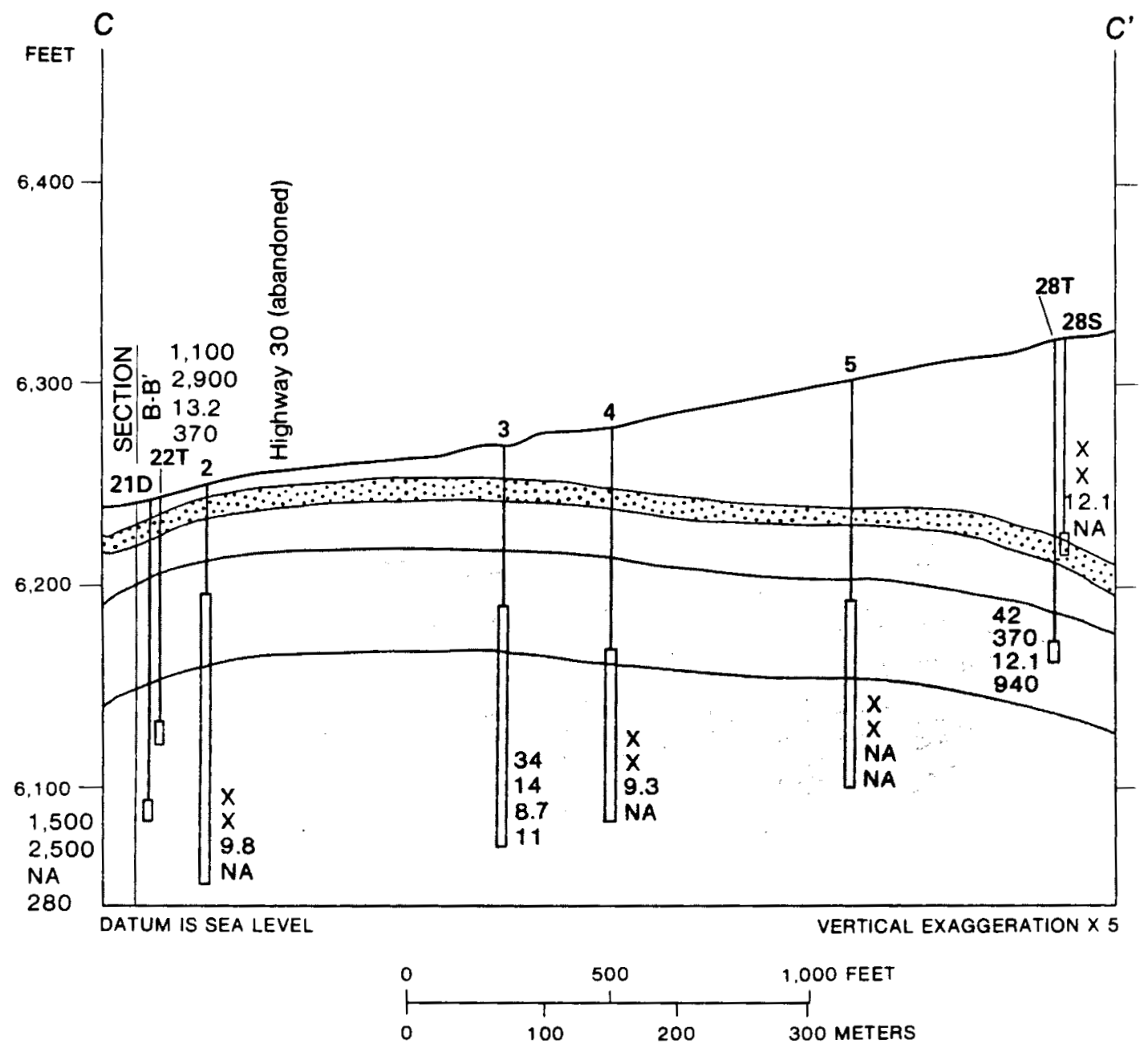

EXPLANATION

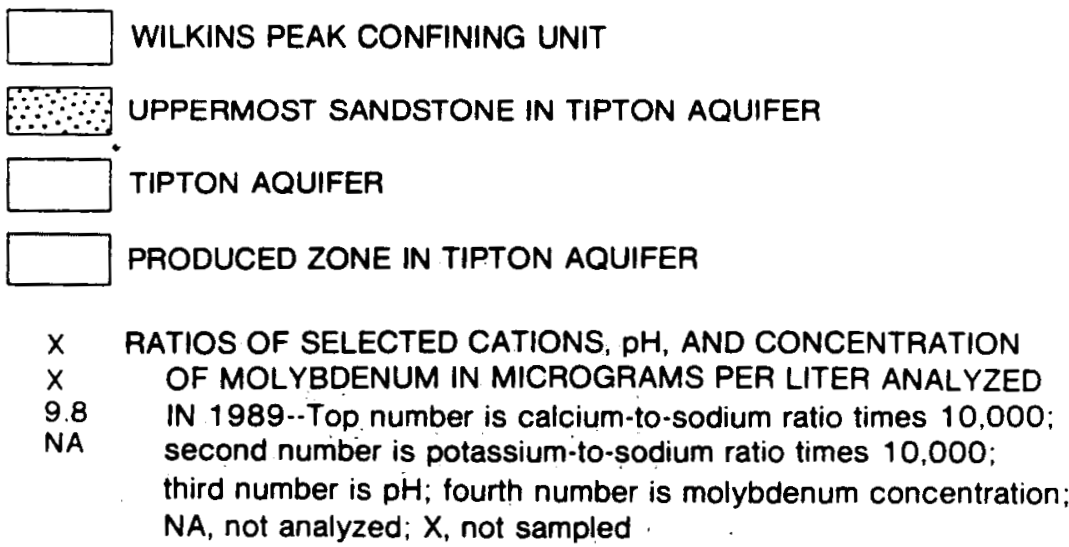

2

WELL AND NUMBER AND OPEN INTERVAL

Figure 22.--Vertical distribution of ratios of selected cations, $\mathrm{pH}$, and concentration of molybdenum at section C.C'. 


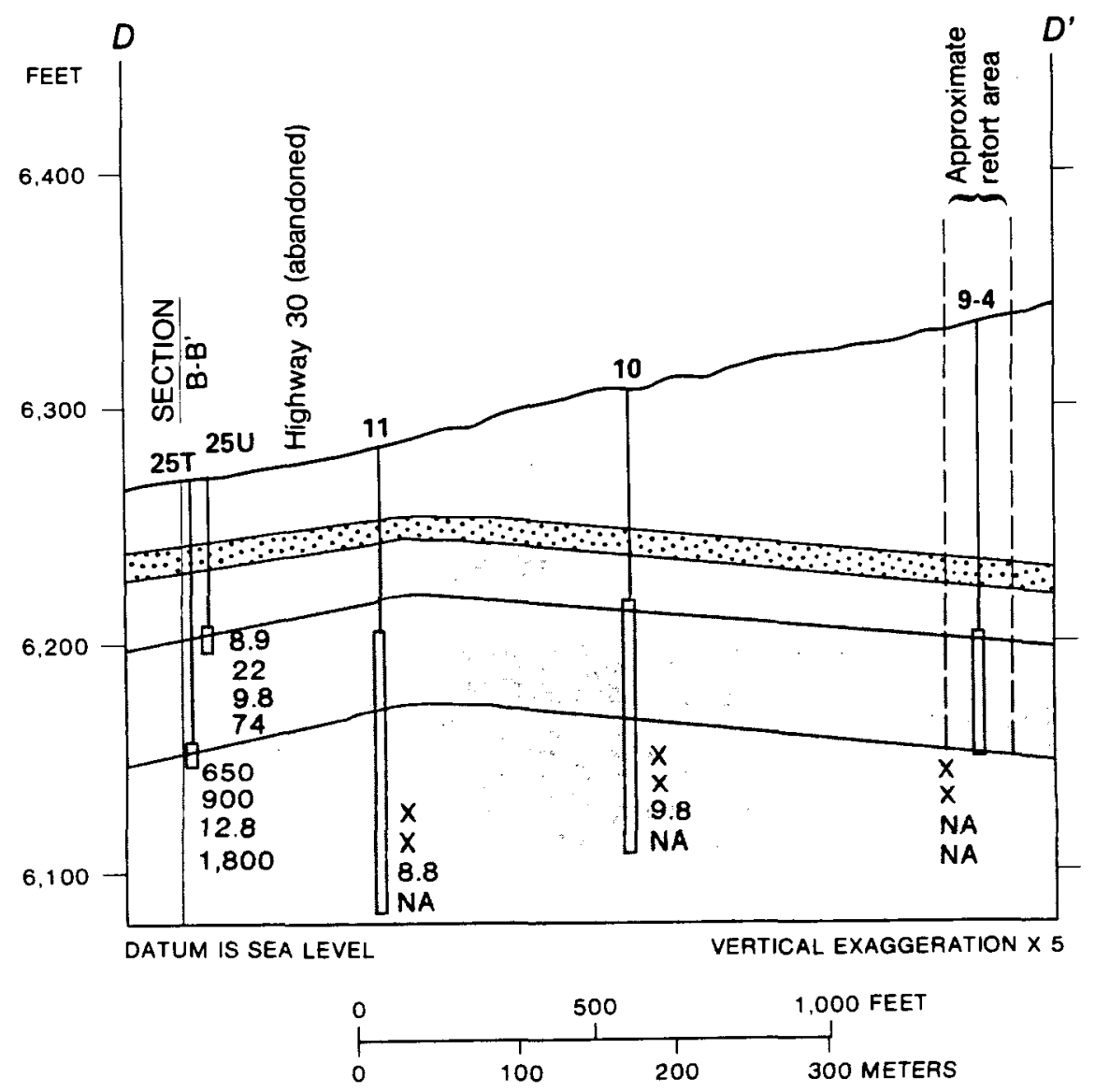

EXPLANATION

WILKINS PEAK CONFINING UNIT

UPPERMOST SANDSTONE IN TIPTON AQUIFER

$\because \because$

TIPTON AQUIFER

PRODUCED ZONE IN TIPTON AQUIFER

650

900

12.8

1,800

$25 T$

1

RATIOS OF SELECTED CATIONS, pH, AND CONCENTRATION OF MOLYBDENUM IN MICROGRAMS PER LITER ANALYZED IN 1989--TOP number is calcium-to-sodium ratio times 10,000 ; second number is potassium-to-sodium ratio times 10,000 ; third number is $\mathrm{pH}$; fourth number is molybdenum concentration; NA, not analyzed; $X$, not sampled

WELL AND NUMBER AND OPEN INTERVAL

Figure 23.--Vertical distribution of ratios of selected cations, $\mathrm{pH}$, and concentrations of molybdenum at section D-D'. 
Indications of Movement of Contaminated Water

Information about the lateral movement of contaminated water away from the retort chamber could be obtained by the identification and monitoring of a conservative tracer--a constituent that moves at the same rate as the water and does not take part in any geochemical, biological, or other reactions in the natural environment. The areal distribution of the tracer, and how that distribution changes with time, can indicate the direction and rate of movement of ground water. In addition, if contaminants also are moving conservatively, then the presence of the tracer in a location also will imply the presence of the contaminant of concern.

Previous investigators at this site have recommended different constituents to be used as conservative indicators of movement of contaminated water. Weand (1978, p. 31) suggests that continued monitoring include major ions (calcium, magnesium, sodium, potassium, carbonate and bicarbonate, sulfate, chloride, and ammonium), total dissolved solids, total organic carbon, and boron. Glover (1988, p. 10) identifies thiocyanate as a conservative tracer of movement of contaminated water; however, analytical difficulties precluded its effective use in this study.

Variations in the areal distribution of different classes of organic compounds in the study area suggest that identification of a conservative tracer to evaluate and to predict contaminant movement may be inappropriate for these contaminants at this site because not all the contaminants are moving conservatively. In addition to ground-water movement, several processes such as adsorption, biodegradation, and precipitation appear to be affecting some of the contaminants, as described in the section "Organic Constituents." Because a conservative tracer only provides information about the effect of ground-water movement on contaminant location, detection of the presence of a conservative tracer will not imply the presence of a contaminant which is affected by the aforementioned immobilization or removal processes. To identify the areal distribution of these contaminants, water samples collected from various locations in the study area must be analyzed for each constituent of concern.

The presence of contaminated water at a discharge site would be an unambiguous indication of movement. Glover (1988, p. 25) believed that dark water observed in seeps above Bitter Creek may indicate that the contaminants of retort water have migrated from the experiment site to Bitter Creek; alternatively, it is possible that this water was naturally occurring dark trona water. (This type of water is described in the section "Pre-Retorting Water Quality.") Glover was unable to obtain a sample of the seep water, so the quantity and significance of the discharge are unknown. A salt crust indicative of a seep was observed and sampled in May 1989; the location of the seep, designated as $S-2$, is shown in Figure 2 and on Plate 1 . The vegetation near this seep appeared healthy to a WDEQ botanist (Rob Donovan, Wyoming Department of Environmental Quality, written commun., 1989), and no organic contaminants associated with the retort water were detected in the sample. Samples of water were taken from seeps at S-1, S-2 and S-3, and analyzed onsite by U.S. Geological Survey personnel using a portable gas chromatograph. No volatile organic compounds were detected. 
Both head and water-quality data could also give an indication of vertical movement--if the head and water quality at paired wells is substantially different, that would imply that there is no exchange of water between deeper and shallower parts of the aquifer at that location. The vertical distribution of contaminants apparent in Figures 14 through 16 and 21 through 23 and the small vertical permeability of the aquifer suggest a stratified system. Small vertical permeability implies that even though head gradients are present in a vertical direction, little or no vertical flow actually occurs; water-quality data support this assertion. In paired wells such as $25 \mathrm{U}$ and $25 \mathrm{~T}$, water quality in the deeper well is distinctly different than that in the shallow well, indicating that little or no vertical mixing is taking place. This stratification was not apparent in earlier studies because of the open-hole design of previous wells, which allowed water from different depths in the aquifer to mix in a sample.

\section{POTENTIALLY APPLICABLE REMEDIATION TECHNIQUES}

Potentially applicable remediation techniques to be considered at the Rock Springs site fall into two groups--those based on removal of the contaminants, and those based on immobilization of the contaminants in the aquifer. Removal techniques include pumping and treating the contaminated ground water, bioreclamation, and mining the site (excavating and removing contaminated soil and aquifer material). Immobilization techniques include the use of grout or polymer to isolate the retort area and surrounding contaminated aquifer material and to prevent ground water from flowing through the area, and techniques to increase the adsorption of contaminants in the ground water onto organic material in the shale. These techniques, and considerations that might affect their application in the study area, are briefly described in the following paragraphs.

Pumping and treating ground water for contaminants has been a commonly used method of remediation. The treatment methods for removing organic and inorganic contaminants from water (once that water has been brought to land surface) include aeration, filtration, ion exchange, reverse osmosis, distillation, incineration, chemical oxidation, carbon adsorption, precipitation, and biological treatment (Yaniga, 1987, p. 17). The low volatility of some of the organic contaminants in the study area, and the presence of a complex mixture of organic and inorganic contaminants could result in the use of more than one treatment technique. The low hydraulic conductivity and anisotropic conditions in the Tipton aquifer may make it difficult to pump the water and to return it to the aquifer after treatment.

In-situ bioreclamation is a naturally occurring process whereby bacteria metabolize the contaminants, breaking them down into other compounds within the matrix of soil or aquifer. Active bioreclamation seeks to enhance the efficiency of these naturally occurring bacteria by injecting needed nutrients and chemicals to create an optimum environment for growth and metabolism. There is a need to monitor extensively during this process to be certain that the by-products of bioreclamation are not in themselves toxic. If the contaminants are chemically complex or present in high concentrations, the bioreclamation may not be effective. The high $\mathrm{pH}$ of the ground water in some parts of the Tipton aquifer also could limit the effectiveness of the technique in those locations, although the water could be treated to lower $\mathrm{pH}$. 
Mining the site would involve excavating all contaminated soil and aquifer material, and removing it for disposal in a location where the contaminants could not reenter a ground or surface water system, although the large volume of affected rock in the study area may make this method impractical.

Containment by grouting is an immobilization technology that could halt or delay spread of the contaminants that may still be present in the retort area. The depth of the material at the Rock Springs site could prevent construction of a slurry wall, which is a commonly used method. However, technology developed in the oil industry includes injection of chemical grouts, such as water-soluble polymers, and similar techniques might be applicable to the fractured rock system. If an immobilization technology is implemented, the open-hole type wells also would need to be plugged to prevent vertical movement. Alternatively, specific intervals could be packed off to facilitate future sampling.

Another immobilization technique would involve increasing the adsorption of contaminants onto organic material in the shale, or causing them to precipitate-form stable, nonsoluble compounds. Some of these processes appear to be occurring naturally for some constituents.

To evaluate the applicability of these remediation techniques, further information about the geologic system would be useful. Ground-water movement appears to be controlled by several mechanisms. The primary flow path of ground water could involve movement through the following: (1) the pores of the sandstone layer at the base of the Wilkins Peak Member; (2) a network of small, closely spaced fractures within the oil shale; (3) a small number of large, very permeable, sparsely spaced fractures in the oil shale; or (4) a combination of all three elements. Detailed study, using monitoring of hydraulic heads, hydraulic tests, and tracer tests, could determine which of the four pathways is the controlling factor for flow and transport. Electrical geophysical techniques--surface and borehole--could be used to examine fracture and fracture-zone orientations in the subsurface. Detailed geologic mapping, in addition to the fracture characterization, could assist in describing the complex distribution of lithologies within and between aquifers. The lithologies and rock-matrix properties are important factors in controlling the fate of chemical compounds and in evaluating the applicability of remediation technologies. These data will be useful in well and pump design and in determining the time needed for restoring the aquifer. 
The Rock Springs site is unique because it is the only true in-situ oilshale development in existence; other oil-shale developments use a modified in situ process. Also, the water-quality characteristics of the area are complex. In view of these circumstances, bench and pilot studies may be needed to support the development of remedial alternatives and feasibility analyses. This approach would be consistent with the National Contingency Plan (NCP) and would be similar to the process used by the U.S. Environmental Protection Agency (EPA) for cleanup of Superfund waste sites under the Comprehensive Environmental Response, Compensation, and Liability Act of 1980 (CERCLA) (U.S. Environmental Protection Agency, 1985, p. 1-1 to 1-6). Points to be considered might include the following:

1. Identify alternative technologies applicable to the site. Technologies for aquifer restoration have emerged rapidly during the past several years, and there is little information about technology performance. Bench or pilot studies could assist in the success and economy of the remedial action.

2. Assess risk. When removal or remedial actions are being considered at a hazardous-waste site, possible human risks exist. Information about these $r$ isks is necessary for safety and for making sound decisions concerning remedial action, including consideration of a no-action alternative. The assessment would include hazard identification, dose-response evaluation, human-exposure evaluation, and risk characterization.

3. Define criteria to be used for decisions regarding restoration of the aquifer. These criteria are necessary so that objectives of the response technology can be clearly stated, and so that the scope, length, and cost of the remedial action can be estimated during the evaluation period. 


\section{SUMMARY}

During the oil shortage of the 1970s, the U.S. Department of Energy (DOE) conducted experiments to test in-situ methods of oil recovery from the large reserves of oil shale in Colorado, Wyoming, and Utah. These in-situ experiments involved different methods of fracturing the oil-shale formation and various techniques for heating the oil shale in place to extract the oil from the shale. These processes produced a variety of organic and inorganic byproducts along with oil, some of which has not been removed. On May 25, 1988, the Wyoming Department of Environmental Quality (WDEQ) issued a notice of violation to DOE. DOE was ordered to perform a site characterization as the first step in restoring the ground water to its original condition. This report, prepared by the U.S. Geological Survey in cooperation with DOE, presents the results of that study.

The oil shale is in the Tipton Shale Member of the Green River Formation of Eocene age, which is composed of interbedded shale, oil shale, and tuff with discontinuous beds of sandstone, marlstone, and siltstone. Hydraulic conductivities in the aquifer are small. Eight slug tests conducted in 1989 yielded values ranging from no measurable aquifer response to 1.6 feet per day. Water in the Tipton Shale Member moves mainly through tuff or sandstone beds, bedding planes, and fractures; little water moves through unfractured shale. A regional aquifer, the Wasatch aquifer (part of the Wasatch Formation of Eocene age), underlies the Tipton and is separated from it by a confining unit more than 200 feet thick.

Two potential pathways by which the contaminated water might move from the retort site were investigated as follows: (1) vertical flow, consisting of interformational leakage downward into the underlying Wasatch aquifer; and (2) lateral flow, consisting of flow through tuff beds, bedding planes, and fractures in the shale, or through a sandy layer at the top of the Tipton aquifer, to discharge to nearby Bitter Creek. The investigation led to the conclusion that neither pathway is consistent with flow conditions and contaminant movement in the study area. Hydraulic-head data indicated that the vertical gradient in most parts of the study area is upward from the Wasatch aquifer to the shallower Tipton aquifer; therefore, it is unlikely that the Wasatch aquifer could be contaminated by water from the overlying Tipton aquifer. The potentiometric-surface data also indicated the potential for movement toward Bitter Creek because the areal gradient is generally toward the southwest. However, the small hydraulic conductivities measured in the Tipton aquifer indicate little actual movement of water is taking place. Water discharging from the Tipton aquifer is probably lost by evapotranspiration; streamflow measurements on Bitter Creek upstream and downstream of the retort site indicate that the stream generally is losing water in this reach. Organic contaminants were not detected in water-quality samples from either Bitter Creek or the Wasatch confining unit.

Pre-retorting water quality in the Tipton aquifer at the site is variable areally, but generally is poor, with high concentrations of sodium, bicarbonate and carbonate, and natural organic acids. In some parts of the study area, the water is dark brown. More than 70 identifiable organic compounds were found during the present (1989) study; most of the organic contaminants--aromatic hydrocarbons, phenols, azaarenes, and aliphatic ketones--can be attributed to the retort experiments. 
Seventeen new wells were drilled as part of the present study, and those wells, in addition to wells already at the site, were sampled and the water was analyzed for major inorganic constituents, trace metals, sulfur species including thiocyanate, thiosulfate, tetrathionate, and total sulfur, and volatile and semivolatile organic compounds (EPA schedules 624 and 625). Interference problems made the sulfur species difficult to analyze. High concentrations of volatile and semivolatile organic contaminants, as well as other indicators associated with retort water, were detected in water samples from two wells, $25 \mathrm{U}$ and $32 \mathrm{U}$, screened in the upper part of the produced zone in the oil shale in the Tipton aquifer, about $3 / 8$ to $1 / 2$ mile downgradient of site 9.

Results of the present study show that many of the organic contaminants are not moving conservatively, and, therefore, a conservative tracer is not appropriate to estimate future contaminant locations and concentrations. (A conservative tracer is a constituent that moves at exactly the same rate as the water and does not take part in any geochemical, biological, or other reactions in the natural environment. Where conservative tracers exist, they are generally useful indicators of rates of ground-water movement, contaminant dispersion, and mixing.) Benzene, for example, has been detected in measurable concentrations in only a few wells outside of the retort chamber. Movement of benzene, and several other nonpolar organic compounds such as azaarenes, may be retarded relative to movement of polar compounds and ions, probably because the nonpolar compounds are adsorbed onto organic material in the shale as the water moves slowly through fine-bedding planes and small fractures. Alternatively, these compounds could be degraded by microbiological activity before they have moved more than a few tens of feet from the retort chamber, but the high $\mathrm{pH}$ of the water in the Tipton aquifer makes this mechanism less likely than adsorption. Another possible degradation route may be the interaction of organic compounds with the inorganics at the high pH present in the ground water to form stable, nonsoluble compounds. Watersoluble acetone and phenols, by contrast, are widely dispersed throughout the study region, and have been detected in wells as far as 1/2 mile from the retort chamber. In addition to volatile and semivalatile organic compounds, calcium-to-sodium and potassium-to-sodium ratios and $\mathrm{pH}$ were used in the present study to identify ground-water movement. Vertical distribution of these indicators, and the many very thin beds in the aquifer, imply a stratified system, where waters moving through the upper layers in the Tipton aquifer did not mix with deeper waters. The open-hole design of previous observation wells made it impossible to detect this stratification because their construction allowed water from different depths in the aquifer to mix in a sample. 
Acetone, the contaminant detected most frequently in the aquifer during the study, was present in 28 of 40 analyses. The maximum concentration detected in the aquifer was $980 \mu \mathrm{g} / \mathrm{L}$ at well 320 . No acetone was detected in the retort chamber during sampling in May 1989; however, acetone was present at a concentration of $120 \mathrm{\mu g} / \mathrm{L}$ in August 1989. Benzene was detected in 13 of 36 analyses in the aquifer at a maximum concentration of $17 \mu \mathrm{g} / \mathrm{L}$ (well $25 \mathrm{U}$ ); it was present in the retort chamber at a concentration of $1,300 \mu \mathrm{g} / \mathrm{L}$. Other compounds detected in 10 or more analyses were methylene chloride, 2-propanol,2-methyl, toluene, total xylenes, and bis (2-ethylhexyl) phthalate. The highest concentrations of total semivolatile organic compounds were found at well 25U (over 200,000 $\mu \mathrm{g} / \mathrm{L}$ ) and at well $32 \mathrm{U}$ (about $700,000 \mu \mathrm{g} / \mathrm{L}$ ). (Well locations are shown on Plate 1.) The retort chamber well (well 9-4) only had about $18,000 \mu \mathrm{g} / \mathrm{L}$ of semivolatile constituents, but had a greater concentration of volatile constituents than any other well, over $2,400 \mu \mathrm{g} / \mathrm{L}$. The largest concentration of volatile constituents detected in the aquifer (excluding well 9-4) was about $2,000 \mu \mathrm{g} / \mathrm{L}$ at well $27 \mathrm{~T}$.

Remediation techniques that may be applicable at the site include techniques based on removing the contaminants from the aquifer and those based on immobilizing the contaminants. Before a technology is selected for use, the risks associated with the remedial action (including the no-action alternative) need to be assessed, and the criteria to be used for decisions regarding aquifer restoration need to be defined.

\section{REFERENCES CITED}

Bradley, W.H., 1964, Geology of the Green River Formation and associated Eocene rocks in southwestern Wyoming and adjacent parts of Colorado and Utah: U.S. Geological Survey Professional Paper 496-A.

Carpenter, H.C., 1988, Summary of in-situ oil-shale experiments in the Rock Springs, WY, area: unpublished report prepared for Edgerton, Greer, and Gramerhausen Washington Analytical Services Center, Inc., 10 p.

Cooper, H.H., Jr., Bredehoeft, J.D., and Papadopulos, I.S., i y 7, Response of a finite-diameter well to an instantaneous charge of water: Water Resources Research, v. 3, no. 1, p. 263-269.

Dana, G.F., and Smith, J.W., 1973, Black trona water, Green River basin, in Schell, E.M., ed., Wyoming Geological Association 25th Field Conference Guidebook on the geology and mineral resources of the greater Green River basin: Casper, Wyoming, Prairie Publishing Co., p. 153-156.

Driscoll, F.G., 1986, Groundwater and wells (2d ed.): St. Paul, Minn., Johnson Division, $1089 \mathrm{p}$.

Eddy, C.A., Lindner-Lunsford, J.B., Wallace, J.C., and Wilson, K.E., 1991, Organic and inorganic analyses of water samples from in-situ oil-shale retorting site near Rock Springs, Wyoming, 1989: U.S. Department of Energy Report, $517 \mathrm{p}$. 


\section{REFERENCES CITED--Continued}

Edgerton, Greer, and Gramerhausen Washington Analytical Services Center, Inc., 1988, Bibliography of the in-situ oil-shale publications from experiments conducted near Rock Springs, Wyoming, 1966-1982, Laramie, Wyoming: unpublished report, $7 \mathrm{p}$.

Farrier, D.S., Poulson, R.E., and Fox, J.P., 1980, Interlaboratory, multimethod study of an in-situ produced oil shale process water, in Gale, Charles, ed., Oil Shale Symposium: sampling, analysis and quality assurance, March 1979, U.S. Environmental Protection Agency Industrial Environmental Research Laboratory Report EPA-600/9-80-022, p. 182-210.

Farrier, D.S., Virgona, J.E., Phillips, T.E., and Poulson, R.E., 1978, Environmental research for in-situ oil shale processing: Oil Shale Symposium, 11th, Colorado School of Mines, Proceedings, p. 81-99.

Fox, J.P., Farrier, D.S., and Poulson, R.E., 1978, Chemical characterization and analytical considerations for an in-situ oil-shale process water: Laramie, Wyo., Laramie Energy Technology Center Report of Investigation $78 / 7,47 \mathrm{p}$.

Glover, K.C., 1988, Leachate migration from an in-situ oil-shale retort near Rock Springs, Wyoming: U.S. Geological Survey Water-Supply Paper 2322, $26 \mathrm{p}$.

Heath, R.C., 1983, Basic ground-water hydrology: U.S. Geological Survey Water-Supply Paper 2220, p. 13 (84 p.).

Hvorslev, M.J., 1951, Time lag and soil permeability in groundwater observations: U.S. Army Corps of Engineers Waterways Experimental Station Bulletin 36, Vicksburg, Miss.

Lawlor, D.L., Latham, D.R., Fausett, D.W., and Asplund, R.0., 1979, Post-burn study of the Rock Springs, site 9 in-situ retorting experiment: Oil Shale Symposium, 11th, Colorado School of Mines, Proceedings, p. 221-227.

Leenheer, J.A., and Noyes, T.I., 1986, Effects of organic wastes on water quality from processing of oil shale from the Green River Formation, Colorado, Utah, and Wyoming: U.S. Geological Survey Professional Paper $1338,56 \mathrm{p}$.

Long, A., Jr., Merriam, N.W., and Mones, C.G., 1977, Evaluation of Rock Springs site 9 in-situ oil-shale retorting experiment: 0il Shale Symposium, 10th, Colorado School of Mines, Proceedings, p. 120-135.

Lowham, H.W., Peterson, D.A., Larson, L.R., Zimmerman, E.A., Ringen, B.H., and Mora, K.L., 1985, Hydrology of area 52, Rocky Mountain Coal Province, Wyoming, Colorado, Idaho, and Utah: U.S. Geological Survey WaterResources Investigations Open-File Report 83-761, p. 12.

Martner, B.E., 1986, Wyoming climate atlas: University of Nebraska Press, Lincoln, Nebraska, p. 177-398. 


\section{REFERENCES CITED--Continued}

Papadopulos, S.S., Bredehoeft, J.D., and Cooper, H.H., 1973, On the analysis of slug test data: Water Resources Research, v. 9, no. 4, p. 1087-1089.

Parrish, R.L., Boade, R.R., Stevens, A.L., Long, A., Jr., and Turner, F.T., 1980, The Rock Springs site 12 hydraulic/explosive true in-situ oil-shale fracturing experiment: Sandia Laboratories, Albuquerque, New Mexico, SAND $80-0836,149 \mathrm{p}$.

Phillips, T.E., 1978, Potential methods for resource recovery from black water of the northern Green River basin of Wyoming: Laramie Energy Technology Center Report of Investigation 78/21, $25 \mathrm{p}$.

Smith, V.E., and Weand, B.L., 1977, Summary and analysis of water quality at oil shale study sites: Water Resources Research Institute, Laramie, Wyoming, $58 \mathrm{p}$.

Stuber, H.A., and Leenheer, J.A., 1982, Selective concentration of aromatic bases from water with a resin adsorbent: Analytical Chemistry, v. 55, no. 1, p.111-115.

U.S. Environmental Protection Agency, 1985, Guidance on remedial investigations under CERCLA: EPA publication no. 540/G-85/002, variable pagination.

1986, Quality criteria for water: EPA publication no. 440/5-86-001, variable pagination, approx. $300 \mathrm{p}$.

1988, The Superfund innovative technology evaluation program:

Technology Profiles, EPA publication no. 540/5-88/003, 83 p.

Virgona, J.E., Poulson, R.E., and Spedding, T.J., 1979, Summary of the environmental monitoring at the Rock Springs, Wyoming site no. 9, true insitu oil-shale retorting experiment: Laramie, Wyo., Laramie Energy Technology Center Report of Investigation 79/03, $51 \mathrm{p}$.

Weand, B.L., 1978, Water quality changes at in-situ oil-shale study sites: Water Resources Research Institute, Laramie, Wyo., 42 p.

Western Research Institute, 1988, Report on environmental sampling at the insitu oil-shale experimental area near Rock Springs, Wyoming: unpublished report prepared for U.S. Department of Energy, $28 \mathrm{p}$.

Wyoming Department of Administration and Fiscal Control, 1987, Wyoming data handbook, 1987: The Division of Research and Statistics, Cheyenne, Wyo., p. 215.

Yaniga, P.M., 1987, Alternatives in decontamination for hydrocarboncontaminated aquifers: Physical recovery of petroleum hydrocarbons in ground water, Part 1: p. 11-21. 